\title{
An Analysis of Atlantic Water in the Arctic Ocean Using the Arctic Subpolar Gyre State Estimate and Observations
}

\author{
by \\ Lieutenant Commander Jeffrey Scott Grabon, United States Navy \\ B.S., The Pennsylvania State University (2007) \\ M.S., The Pennsylvania State University (2009) \\ Submitted to the Department of Earth, Atmospheric and Planetary Sciences \\ in partial fulfillment of the requirements for the degree of \\ Master of Science in Physical Oceanography \\ at the \\ MASSACHUSETTS INSTITUTE OF TECHNOLOGY \\ and the \\ WOODS HOLE OCEANOGRAPHIC INSTITUTION
}

September 2020

(C)2020 Jeffrey Scott Grabon.

All rights reserved.

The author hereby grants to MIT and WHOI permission to reproduce and to distribute publicly paper and electronic copies of this thesis document in whole or in part in any medium now known or hereafter created.

Author

Department of Earth, Atmospheric and Planetary Sciences Massachusetts Institute of Technology \& Woods Hole Oceanographic Institution

August 7, 2020

Certified by

John Toole

Senior Scientist

Woods Hole Oceanographic Institution

Thesis Supervisor

Accepted by .

Glenn R. Flierl

Chairman, Joint Committee for Physical Oceanography Massachusetts Institute of Technology 


\title{
An Analysis of Atlantic Water in the Arctic Ocean Using the Arctic Subpolar Gyre State Estimate and Observations
}

\author{
by \\ Lieutenant Commander Jeffrey Scott Grabon, United States Navy \\ Submitted to the Department of Earth, Atmospheric and Planetary Sciences \\ Massachusetts Institute of Technology \\ \& Woods Hole Oceanographic Institution \\ on August 7, 2020, in partial fulfillment of the \\ requirements for the degree of \\ Master of Science in Physical Oceanography
}

\begin{abstract}
The Atlantic Water (AW) Layer in the Arctic Subpolar gyre sTate Estimate (ASTE), a regional, medium-resolution coupled ocean-sea ice state estimate, is analyzed for the first time using bounding isopycnals. A surge of AW, marked by rapid increases in mean AW Layer potential temperature and AW Layer thickness, begins two years into the state estimate (2004) and traverses the Arctic Ocean along boundary current pathways at approximately $2 \mathrm{~cm} / \mathrm{s}$. The surge also alters AW flow direction and speed including a significant reversal in flow direction along the Lomonosov Ridge. The surge results in a new quasi-steady AW flow from 2010 through the end of the state estimate period in 2017. The time-mean AW circulation during this time period indicates a significant amount of AW spreads over the Lomonosov Ridge rather than directly returning along the ridge to Fram Strait. A threelayer depiction of ASTE's overturning circulation within the AO indicates AW is converted to colder, fresher Surface Layer water at a faster rate than is transformed to Bottom Water (1.2 Sv vs. $0.4 \mathrm{~Sv}$ ). Observed AW properties compared to ASTE output indicate increasing misfit during the simulated period with ASTE's AW Layer generally being warmer and thicker than in observations.
\end{abstract}

Thesis Supervisor: John Toole

Title: Senior Scientist

Woods Hole Oceanographic Institution 


\section{Acknowledgments}

This research was funded via the United States Navy's Civilian Institution Program with the MIT/WHOI Joint Program (JP).

The thesis supervisor's participation in this project was supported by National Science Foundation-Grant \#PLR-1603660 and by Office of Naval Research-Grant \#N000141612381. This project, specifically ASTE developed by Dr. An T. Nguyen, is also supported by National Science Foundation-Grant \#PLR-1603903.

The Ice-Tethered Profiler data were collected and made available by the Ice-Tethered Profiler Program (Toole et al., 2011; Krishfield et al., 2008) based at the Woods Hole Oceanographic Institution (http://www.whoi.edu/itp).

Some CTDs used in this research were collected and made available by the Beaufort Gyre Exploration Program based at the Woods Hole Oceanographic Institution (https:// www.whoi.edu/beaufortgyre) in collaboration with researchers from Fisheries and Oceans Canada at the Institute of Ocean Sciences.

Thank you Dr. An T. Nguyen, Oden Institute for Computational Engineering and Sciences, University of Texas, for providing the ASTE output for this project as well as quick, thorough responses to my inquiries.

Thank you Dr. Christopher Piecuch, Assistant Scientist at the Woods Hole Oceanographic Institution, for his guidance explaining the contents of various ASTE files and stepping through how to apply them to the problem at hand. His in-depth discussions provided a framework to tackle several tasks.

Thank you Richard A. Krishfield, Senior Research Specialist at Woods Holde Oceanographic Institution, for his help obtaining observations to conduct this analysis.

I especially want to express my gratitude to my advisor, Dr. John Toole, for providing his support and guidance over the last two years. When I arrived at WHOI, I searched for a faculty member with a project related to the Arctic Ocean. He proposed an analysis of the Atlantic Water Layer in ASTE. Not really knowing what I was agreeing to, I decided this would be a terrific opportunity. In retrospect, it truly was! I was handed an external hard drive full of output and off I went. Ten years removed from academia and eight years into my naval career, my computer programming skills were quite rusty and severely lacking. I had no idea what an isopycnal was and an environment stratified by salinity was especially 
foreign. Clearly, I needed an advisor with patience who was willing to build an oceanographer from the bottom up. Perhaps he had no idea what he was getting himself into either! He provided the right amount of direction without micromanaging and was understanding when I needed more time to accomplish a task. I think it is an especially noteworthy achievement that we were able to complete this project with only virtual meetings during the final six months as a result of the pandemic (COVID-19).

This thesis is only a portion of the academic work required for graduation. My classmates and friends were an integral part of the experience as we commiserated through coursework together. Thank you Stephan Gallagher, Praneeth Gurumurthy, Hanyuan Liu, Martin Velez Pardo, and Casey Densmore who were my office mates on the sixteenth floor of MIT's Green Building. I especially want to express my appreciation to Casey who was many times my one-stop resource for MATLAB and coursework help. I would also like to thank fellow shipmates Brendan O’Neill, Chris Dolan, Mike Humara, John Li, and Kyle Kausch. My student mentor, Astrid Pacini, was also a helpful resource for navigating this program.

Finally, I'd like to thank my family. As a native New Englander, I was able to spend time with family I used to only have the opportunity to see a couple weeks a year. I especially want to thank my wife, Lindsey Grabon, and daughter, Norah Grabon, for their love and support during this tour. This adventure began between deployments when Lindsey and I flew to Osaka and Tokyo so I could take the GRE. It was not administered electronically on Okinawa and was required for the MIT/WHOI JP application. After being accepted, we arrived in Massachusetts with Lindsey eight months pregnant. There was a quick turn around to establish a home but we were fully prepared to welcome Norah to the world. This tour ended with all three of us at home together for the final six months due to the COVID-19 pandemic. While it introduced many new challenges, it provided memories I'll cherish for a lifetime. 


\section{Contents}

1 Introduction $\quad 19$

1.1 Motivation . . . . . . . . . . . . . . . . . . . 19

1.2 ASTE Background . . . . . . . . . . . . . . . . . 23

1.3 Background on ITPs and CTDs . . . . . . . . . . . . . . 25

2 Methods $\quad 27$

2.1 CTDs and ITPs . . . . . . . . . . . . . . . . 27

2.2 Basin Assignment . . . . . . . . . . . . . . . . . . . . . 28

2.3 Atlantic Water Boundary Current Contours . . . . . . . . . . . . . . . 32

2.4 Atlantic Water Bounding Isopycnals . . . . . . . . . . . . . . . . . 34

2.5 Ocean Heat Content . . . . . . . . . . . . . . . . . . . . 37

2.6 Transport Streamfunction . . . . . . . . . . . . . . . . 38

2.7 Time-Mean Atlantic Water Layer Streamlines and Properties . . . . . . . . . 40

2.8 ASTE vs. Observed Atlantic Water Properties . . . . . . . . . . . . 40

$\begin{array}{lll}3 & \text { Results } & 43\end{array}$

3.1 Atlantic Water Time-Mean Properties . . . . . . . . . . . . . . . . 43

3.2 Atlantic Water Time-Mean Circulation . . . . . . . . . . . . . . . 48

3.3 Atlantic Water Time-Varying Circulation . . . . . . . . . . . . 54

3.3.1 Seasonal Variability . . . . . . . . . . . . . . . 54

3.3 .2 Interannual Variability . . . . . . . . . . . . . 57

3.4 Atlantic Water Space-Time Variability . . . . . . . . . . . . . . 64

4 Conclusions and Future Work $\quad 85$ 
THIS PAGE INTENTIONALLY LEFT BLANK 


\section{List of Figures}

1-1 A simplified, time-mean depiction of the AW circulation in the Nordic Seas and Arctic Ocean inferred from sparse hydrographic observations. AW enters the AO through Fram Strait and the Barents Sea. The two branches meet in the St. Anna Trench as they circulate cyclonically in the AO. Bifurcations of the AW circumpolar boundary current occur at each ridge. Image from Mauritzen et al., 2013 [1] which was adapted from Rudels et al., 2012 [2]. . . 21

2-1 Major geographic and bathymetric features in the AO, Nordic Seas and North Atlantic. Image is from Mauritzen et al., 2013 [1] which was adapted from Rudels et al., 2012 [2]. . . . . . . . . . . . . . . . . . . . . 29 
2-2 The AO partitioning scheme developed to examine AW properties. On the Eurasian side of each basin, circumpolar subbasins are colored red and mid subbasins are blue. On the North American side, circumpolar subbasins are colored yellow and mid subbasin are orange. Numbered subbasins are as follows: 1. Eurasian Circumpolar Nansen Basin (ECNB), 2. Eurasian Mid Nansen Basin (EMNB), 3. Eurasian Circumpolar Amundsen Basin (ECAB), 4. Eurasian Mid Amundsen Basin (EMAB), 5. Eurasian Circumpolar Makarov Basin (ECMB), 6. Eurasian Mid Makarav Basin (EMMB), 7. Eurasian Circumpolar Canada Basin (ECCB), 8. Eurasian Mid Canada Basin (EMCB), 9. North American Circumpolar Canada Basin (NCCB), 10. North American Mid Canada Basin (NMCB), 11. North American Circumpolar Makarov Basin (NCMB), 12. North American Mid Makarov Basin (NMMB), 13. North American Greenland Circumpolar Amundsen Basin (NGCAB), 14. North American Poleward Mid Amundsen Basin (NPMAB), 15. North American Svalbard Circumpolar Amundsen Basin Svalbard (NSCAB), 16. North American Fram Mid Amundsen Basin (NFMAB), 17. North American Circumpolar Nansen Basin (NCNB), 18. North American Mid Nansen Basin

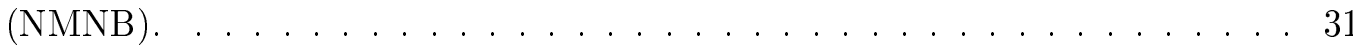

2-3 The Lomonosov Boundary Current contour is depicted in red. The contour is produced using the circumpolar and mid subbasin boundaries depicted in Figure 2-2 and a $100 \mathrm{~km}$ buffer region along the Lomonosov Ridge. Letters mark the beginning and end of the contour as well as subbasin transitions. The blue contour is the $100 \mathrm{~m}$ isobath. . . . . . . . . . . . . 32

2-4 The Circumpolar Boundary Current contour is depicted in red which follows the subbasin boundaries depicted in Figure 2-2. Letters mark the beginning and end of the contour as well as subbasin transitions. The blue contour is the $100 \mathrm{~m}$ isobath. . . . . . . . . . . . . . . 33

2-5 The AW Layer bounding isopycnals for this study plotted on mean potential density referenced to 200 dbar versus mean potential temperature referenced to the 0 dbar profiles for the EMNB (green) and NMCB (blue) subbasins with one standard deviation about the mean shaded. Subbasin depictions and acronyms are provided in Figure $2-2 \ldots \ldots \ldots$. . . . . . . . 35 
2-6 The mean depth versus potential temperature profiles for the EMNB (green) and NMCB (blue) subbasins. The mean depths (dashed) and standard deviation (dotted) of the bounding AW isopycnals are plotted in the same color as their associated subbasin profile with the $1028.2 \mathrm{~kg} / \mathrm{m}^{3}$ isopycnal located higher in the water column than $1028.9 \mathrm{~kg} / \mathrm{m}^{3}$. . . . . . . . . . . . . 36

2-7 The AW Layer bounding isopycnals for this study plotted against mean pressure versus potential density profiles for the EMNB (green) and NMCB (blue) subbasins with one standard deviation about the mean shaded. . . . . . . . 37

2-8 The ASTE grid $\mathrm{x}$ - and $\mathrm{y}$-coordinates relative to major geographic features overlaid on bathymetry. Latitude lines are drawn every $5^{\circ}$ and longitude

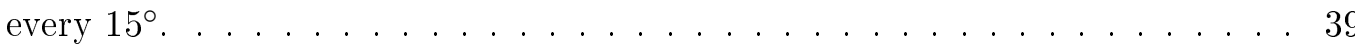

3-1 Mean AW Layer $\left(1028.2 \mathrm{~kg} / \mathrm{m}^{3}-1028.9 \mathrm{~kg} / \mathrm{m}^{3}\right)$ potential temperature, $\Theta_{a v}$, from January 2010 through December 2017 in ASTE. Values are displayed only for those grid cells where both upper and lower bounding isopycnals existed in each monthly mean profile. . . . . . . . . . . . . . . . . . . . 44

3-2 Mean AW Layer $\left(1028.2 \mathrm{~kg} / \mathrm{m}^{3}-1028.9 \mathrm{~kg} / \mathrm{m}^{3}\right)$ thickness from January 2010 through December 2017 in ASTE. Values are displayed only for those grid cells where both upper and lower bounding isopycnals existed in each monthly

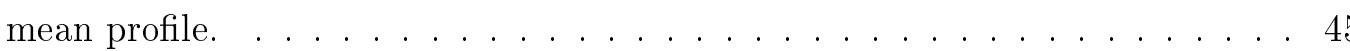

3-3 Mean $1028.2 \mathrm{~kg} / \mathrm{m}^{3}$ isopycnal depth from January 2010 through December 2017 in ASTE. Only grid cells where both top and bottom AW bounding isopycnals exist in every monthly mean file are displayed. . . . . . . . . . . . 47

3-4 Mean $1028.9 \mathrm{~kg} / \mathrm{m}^{3}$ isopycnal depth from January 2010 through December 2017 in ASTE. Values are displayed only for those grid cells where both upper and lower bounding isopycnals existed in each monthly mean profile. . . . . . 48

3-5 The full (divergent and non-divergent) transport streamfunction for the mean AW Layer $\left(1028.2 \mathrm{~kg} / \mathrm{m}^{3}\right.$ - $\left.1028.9 \mathrm{~kg} / \mathrm{m}^{3}\right)$ from January 2010 through December 2017 in ASTE output. The contour interval is $0.25 \mathrm{~Sv}$. Bathymetry is indicated with color. . . . . . . . . . . . . . 50 50 
3-6 The non-divergent Transport Streamfunction for the mean AW Layer (1028.2 $\mathrm{kg} / \mathrm{m}^{3}$ ) - $1028.9 \mathrm{~kg} / \mathrm{m}^{3}$ ) from January 2010 through December 2017 of monthly mean ASTE output. The contour interval is $0.25 \mathrm{~Sv}$. . . . . . . . . . . . 51

3-7 Streamlines for the mean AW Layer velocity from January 2010 through De-

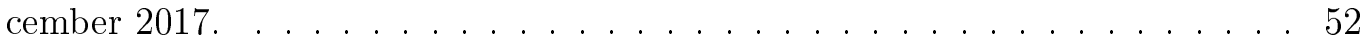

3-8 The mean overturning circulation for the Surface Layer, AW Layer, and Bottom Layer from January 2010 through December 2017 in ASTE. . . . . . . . 54

3-9 The average seasonal cycle of volume transport for the AW inflow through Fram Strait (red, dash-dot), AW outflow through Fram Strait (blue, solid), and AW inflow through the Barents Sea (red, dashed) for each month from January 2010 through December 2017. The locations used to calculate the volume transport are depicted in Figures 3-5 and 3-6. The location used for the Barents Sea inflow is off the coast of Novaya Zemlya. . . . . . . . . . . . 55

3-10 The average speed of the AW Layer for each month along the Lomonosov Boundary Current contour from 2010-2017. . . . . . . . . . . . . . 56

3-11 The average AW Layer speed for each month along the Circumpolar Boundary Current contour from 2010-2017. . . . . . . . . . . . . . . . . 57

3-12 The average volume transport for the AW inflow through Fram Strait (red, dash-dot), AW outflow through Fram Strait (blue, solid), and AW inflow through the Barents Sea (red, dashed) for each month of ASTE output. The locations used to calculate the volume transport are depicted in Figures 3-5 and 3-6 with the Barents Sea inflow based on the coordinates off the coast of Novaya Zemlya. . . . . . . . . . . . . . . . . . . . . . 58

3-13 The average AW speed along the Lomonosov Boundary Current contour for each month of ASTE output. . . . . . . . . . . . . . . . 59

3-14 The average AW speed along the Circumpolar Boundary Current contour for each month of ASTE output. . . . . . . . . . . . . . . . . . . 60

3-15 Monthly mean AW Layer $\left.\left(1028.2 \mathrm{~kg} / \mathrm{m}^{3}\right)-1028.9 \mathrm{~kg} / \mathrm{m}^{3}\right)$ velocity at four year intervals beginning in January 2002 for grid locations where both AW bounding isopycnals exist. Color shading identifies the AW speed while direction is indicated with streamlines. The $500 \mathrm{~m}$ bathymetry contour is indicated

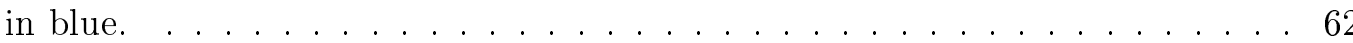


3-16 Top: The grid-relative AW Layer velocity angle along the Lomonosov Boundary Current contour as a function of time ( $\mathrm{y}$-axis) and space ( $\mathrm{x}$-axis). The angle definitions are as follows: $0^{\circ}$ is grid-relative East, $90^{\circ}$ is grid-relative North, $180^{\circ}$ or $-180^{\circ}$ is grid-relative West, and $-90^{\circ}$ is grid-relative South. Vertical dashed lines show subbasin transitions along the contour with labels on the top $\mathrm{x}$-axis corresponding to the locations on the contour identified in Figure 2-3. Bottom: The AW speed along the contour as a function of time

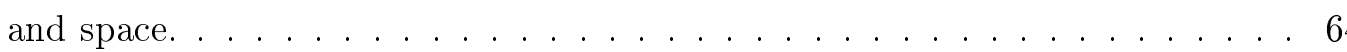

3-17 Monthly mean AW Layer potential temperature, $\Theta_{a v}$, at four year intervals for the duration of the ASTE output. Only ASTE grid locations with both upper and lower AW bounding isopycnals are plotted. . . . . . . . . . 66

3-18 Monthly mean AW Layer thickness at four year intervals for the duration of the ASTE output. Only ASTE grid locations where both upper and lower isopycnals exist are plotted. . . . . . . . . . . . . . . . . . 67

3-19 Monthly mean $1028.2 \mathrm{~kg} / \mathrm{m}^{3}$ isopycnal depth at four year intervals for the duration of the ASTE output. Only ASTE grid locations where both upper and lower isopycnals exist are plotted. . . . . . . . . . . . . . . 69

3-20 Monthly mean $1028.9 \mathrm{~kg} / \mathrm{m}^{3}$ isopycnal depth at four year intervals for the duration of the ASTE output. Only ASTE grid locations where both upper and lower isopycnals exist are plotted. . . . . . . . . . . . . . 70

3-21 Top: Time versus distance along the Lomonosov Boundary Current contour of AW Layer potential temperature, $\Theta_{a v}$. Bottom: Time versus distance along the Circumpolar Boundary Current contour of AW llyer potential temperature, $\Theta_{a v}$. Vertical dashed lines indicate subbasin transition locations with letters on the top axis corresponding to locations identified in Figures 2-3 and 2-4. The distance along each contour is identified on the bottom axis. . . . . . 72

3-22 Top: Time versus distance along the Lomonosov Boundary Current contour of AW Layer thickness. Bottom: Time versus distance along the Circumpolar Boundary Current contour of AW Layer thickness. Vertical dashed lines indicate subbasin transition locations with letters on the top axis corresponding to locations identified in Figures 2-3 and 2-4. The distance along each contour is identified on the bottom axis. . . . . . . . . . . . . . . 73 
3-23 Top: Time versus distance along the Lomonosov Boundary Current contour of the AW upper boundary, $1028.2 \mathrm{~kg} / \mathrm{m}^{3}$, depth. Bottom: Time versus distance along the Circumpolar Boundary Current contour of the AW upper boundary, $1028.2 \mathrm{~kg} / \mathrm{m}^{3}$, depth. Vertical dashed lines indicate subbasin transition locations with letters on the top axis corresponding to locations identified in Figures 2-3 and 2-4. The distance along each contour is identified on the

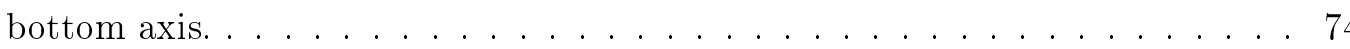

3-24 Top: Time versus distance along the Lomonosov Boundary Current contour of the AW lower boundary, $1028.9 \mathrm{~kg} / \mathrm{m}^{3}$, depth. Bottom: Time versus distance along the Circumpolar Boundary Current contour of the AW lower boundary, $1028.9 \mathrm{~kg} / \mathrm{m}^{3}$, depth. Vertical dashed lines indicate subbasin transition locations with letters on the top axis corresponding to locations identified in Figures 2-3 and 2-4. The distance along each contour is identified on the bottom axis. . . . . . . . . . . . . . . . . 75

3-25 Top Left: The difference between the observed (CTD or ITP) AW $\Theta_{a v}$ and the ASTE AW $\Theta_{a v}$ for the closest grid location to the observation at the time of each observation in the EMNB subbasin. A 36 month running mean of the differences is plotted in a black dashed line. Top Right: The ASTE AW $\Theta_{a v}$ for the closest grid location to the observation during the month of the observation. The black dashed line is a 36 month running mean of the ASTE AW $\Theta_{a v}$ values at the nearest grid location to the observation. The red line is the overall subbasin mean ASTE AW $\Theta_{a v}$ value. Bottom Left: The observed AW $\Theta_{a v}$ for CTDs (squares) and ITP (circles). The red line is the overall subbasin mean ASTE AW $\Theta_{a v}$ value. Bottom Right: The number of observations in the EMNB subbasin for each month of ASTE output. . . . . . 77 
3-26 Top Left: The difference between the observed (CTD or ITP) AW thickness and the ASTE AW thickness for the closest grid location to the observation at the time of each observation in the EMNB subbasin. A 36 month running mean of the differences is plotted in a black dashed line. Top Right: The ASTE AW thickness for the closest grid location to the observation during the month of the observation. The black dashed line is a 36 month running mean of the ASTE AW thickness values at the nearest grid location to the observation. The red line is the overall subbasin mean ASTE AW thickness value. Bottom Left: The observed AW thickness for CTDs (squares) and ITP (circles). The red line is the overall subbasin mean ASTE AW thickness value. Bottom Right: The number of observations in the EMNB subbasin for each month of ASTE output. . . . . . . . . . . . . . 78

3-27 Top Left: The difference between the observed (CTD or ITP) $1028.2 \mathrm{~kg} / \mathrm{m}^{3}$ depth and the ASTE $1028.2 \mathrm{~kg} / \mathrm{m}^{3}$ depth for the closest grid location to the observation at the time of each observation in the EMNB subbasin. A 36 month running mean of the differences is plotted in a black dashed line. Top Right: The ASTE $1028.2 \mathrm{~kg} / \mathrm{m}^{3}$ depth for the closest grid location to the observation during the month of the observation. The black dashed line is a 36 month running mean of the ASTE $1028.2 \mathrm{~kg} / \mathrm{m}^{3}$ depth values at the nearest grid location to the observation. The red line is the overall subbasin mean ASTE $1028.2 \mathrm{~kg} / \mathrm{m}^{3}$ depth value. Bottom Left: The observed 1028.2 $\mathrm{kg} / \mathrm{m}^{3}$ depth for CTDs (squares) and ITP (circles). The red line is the overall subbasin mean ASTE $1028.2 \mathrm{~kg} / \mathrm{m}^{3}$ depth value. Bottom Right: The number of observations in the EMNB subbasin for each month of ASTE output. . . . 79 
3-28 Top Left: The difference between the observed (CTD or ITP) $1028.9 \mathrm{~kg} / \mathrm{m}^{3}$ depth and the ASTE $1028.9 \mathrm{~kg} / \mathrm{m}^{3}$ depth for the closest grid location to the observation at the time of each observation in the EMNB subbasin. A 36 month running mean of the differences is plotted in a black dashed line. Top Right: The ASTE $1028.9 \mathrm{~kg} / \mathrm{m}^{3}$ depth for the closest grid location to the observation during the month of the observation. The black dashed line is a 36 month running mean of the ASTE $1028.9 \mathrm{~kg} / \mathrm{m}^{3}$ depth values at the nearest grid location to the observation. The red line is the overall subbasin mean ASTE $1028.9 \mathrm{~kg} / \mathrm{m}^{3}$ depth value. Bottom Left: The observed 1028.9 $\mathrm{kg} / \mathrm{m}^{3}$ depth for CTDs (squares) and ITP (circles). The red line is the overall subbasin mean ASTE $1028.9 \mathrm{~kg} / \mathrm{m}^{3}$ depth value. Bottom Right: The number of observations in the EMNB subbasin for each month of ASTE output. . . . 80

3-29 Top Left: The difference between the observed (CTD or ITP) AW $\Theta_{a v}$ and the ASTE AW $\Theta_{a v}$ for the closest grid location to the observation at the time of each observation in the NMCB subbasin. A 36 month running mean of the differences is plotted in a black dashed line. Top Right: The ASTE AW $\Theta_{a v}$ for the closest grid location to the observation during the month of the observation. The black dashed line is a 36 month running mean of the ASTE AW $\Theta_{a v}$ values at the nearest grid location to the observation. The red line is the overall subbasin mean ASTE AW $\Theta_{a v}$ value. Bottom Left: The observed AW $\Theta_{a v}$ for CTDs (squares) and ITP (circles). The red line is the overall subbasin mean ASTE AW $\Theta_{a v}$ value. Bottom Right: The number of observations in the NMCB subbasin for each month of ASTE output. . . . . . 81 
3-30 Top Left: The difference between the observed (CTD or ITP) AW thickness and the ASTE AW thickness for the closest grid location to the observation at the time of each observation in the NMCB subbasin. A 36 month running mean of the differences is plotted in a black dashed line. Top Right: The ASTE AW thickness for the closest grid location to the observation during the month of the observation. The black dashed line is a 36 month running mean of the ASTE AW thickness values at the nearest grid location to the observation. The red line is the overall subbasin mean ASTE AW thickness value. Bottom Left: The observed AW thickness for CTDs (squares) and ITP (circles). The red line is the overall subbasin mean ASTE AW thickness value. Bottom Right: The number of observations in the NMCB subbasin for each month of ASTE output. . . . . . . . . . . . . . . 82

3-31 Top Left: The difference between the observed (CTD or ITP) $1028.2 \mathrm{~kg} / \mathrm{m}^{3}$ depth and the ASTE $1028.2 \mathrm{~kg} / \mathrm{m}^{3}$ depth for the closest grid location to the observation at the time of each observation in the NMCB subbasin. A 36 month running mean of the differences is plotted in a black dashed line. Top Right: The ASTE $1028.2 \mathrm{~kg} / \mathrm{m}^{3}$ depth for the closest grid location to the observation during the month of the observation. The black dashed line is a 36 month running mean of the ASTE $1028.2 \mathrm{~kg} / \mathrm{m}^{3}$ depth values at the nearest grid location to the observation. The red line is the overall subbasin mean ASTE $1028.2 \mathrm{~kg} / \mathrm{m}^{3}$ depth value. Bottom Left: The observed 1028.2 $\mathrm{kg} / \mathrm{m}^{3}$ depth for CTDs (squares) and ITP (circles). The red line is the overall subbasin mean ASTE $1028.2 \mathrm{~kg} / \mathrm{m}^{3}$ depth value. Bottom Right: The number of observations in the NMCB subbasin for each month of ASTE output. . . . 83 
3-32 Top Left: The difference between the observed (CTD or ITP) $1028.9 \mathrm{~kg} / \mathrm{m}^{3}$ depth and the ASTE $1028.9 \mathrm{~kg} / \mathrm{m}^{3}$ depth for the closest grid location to the observation at the time of each observation in the NMCB subbasin. A 36 month running mean of the differences is plotted in a black dashed line. Top Right: The ASTE $1028.9 \mathrm{~kg} / \mathrm{m}^{3}$ depth for the closest grid location to the observation during the month of the observation. The black dashed line is a 36 month running mean of the ASTE $1028.9 \mathrm{~kg} / \mathrm{m}^{3}$ depth values at the nearest grid location to the observation. The red line is the overall subbasin mean ASTE $1028.9 \mathrm{~kg} / \mathrm{m}^{3}$ depth value. Bottom Left: The observed 1028.9 $\mathrm{kg} / \mathrm{m}^{3}$ depth for CTDs (squares) and ITP (circles). The red line is the overall subbasin mean ASTE $1028.9 \mathrm{~kg} / \mathrm{m}^{3}$ depth value. Bottom Right: The number of observations in the NMCB subbasin for each month of ASTE output. . . . 84 


\section{Chapter 1}

\section{Introduction}

The Arctic Ocean (AO), one of Earth's five oceans, may be considered a mediterranean sea since it is nearly enclosed with inflows and outflows through straits which connect the Arctic with the subpolar oceans. Differences in the water properties of the in- and out-flows manifest the $\mathrm{AO}$ water mass transformations associated with the circulation. Due to water column temperatures in the AO being near freezing, salinity, rather than temperature, exerts primary control of water density, and thus the stratification within the AO. Inflow from the Pacific Ocean occurs through the Bering Strait between Russia and Alaska and provides relatively fresh water $\left(\mathrm{S}_{A} \sim 32.5\right)[3]$. In contrast, Atlantic inflow is relatively warm and salty. Due to its higher salinity and resulting higher density, Atlantic Water (AW) is found at greater depth than the Pacific Water. The stored heat in the AW has the capacity to melt all of the sea ice if brought to the surface [4].

This study will use both observations and model output to understand the distribution and circulation of AW in the AO. Observations are sparse in the AO owing to its difficult operating environment (sea ice and extreme cold) and consequently its remoteness. Thus, models are essential to provide insight into the processes governing the AW movement and water property changes in the AO.

\subsection{Motivation}

Inflow from the Atlantic Ocean via the Nordic Seas occurs in two main branches: one traversing the Fram Strait between Svalbard and Greenland and the other passing through the northern Barents Sea as shown in Figure 1-1. This relatively warm, salty water is 
called Atlantic Water (AW) due to its origin. AW has a higher temperature compared to most of the other water mass types in the AO. It is therefore often characterized as a local temperature maximum in the vertical. Each AO inflow branch has slightly different characteristics due to their disparate pathways in the Nordic Seas. The Fram Strait AW is around $2.5^{\circ} \mathrm{C}$ with an $\mathrm{S}_{A}$ of 34.95 while the inflow of $\mathrm{AW}$ from the Barents Sea is around $1^{\circ} \mathrm{C}$ with an $\mathrm{S}_{A}$ of 34.85 [5]. Estimates of the amount of $\mathrm{AW}$ each branch contributes to the AO has varied between studies. Best time-averaged AW transport estimates from moored arrays in the Fram Strait indicate $3.0 \pm 0.2 \mathrm{~Sv}$ enters the AO through the Fram Strait in the West Spitsbergen Current [6] while approximately 1.8 Sv of AW passes through the Barents Sea opening [7].

AW is generally in contact with the surface when it enters the AO through the Fram Strait and is therefore directly influenced by interactions with the overlying atmosphere and sea ice. These interactions cool and freshen the AW as it begins its complex, convoluted traverse through the Arctic. While a portion of the inflow recirculates near Fram Strait [8], a significant fraction of the inflow through Fram Strait turns east upon entering the AO to form a boundary current along the continental slope. AW from the Barents Sea is composed of waters from the Norwegian Coastal Current. This water is freshened by runoff from the Norwegian Coast and sea ice melt in the northern Barents Sea. In comparison to the Fram Strait branch, the Barents Sea branch experiences comparatively more cooling due to winter convection over shallower depths $[9,10]$. 


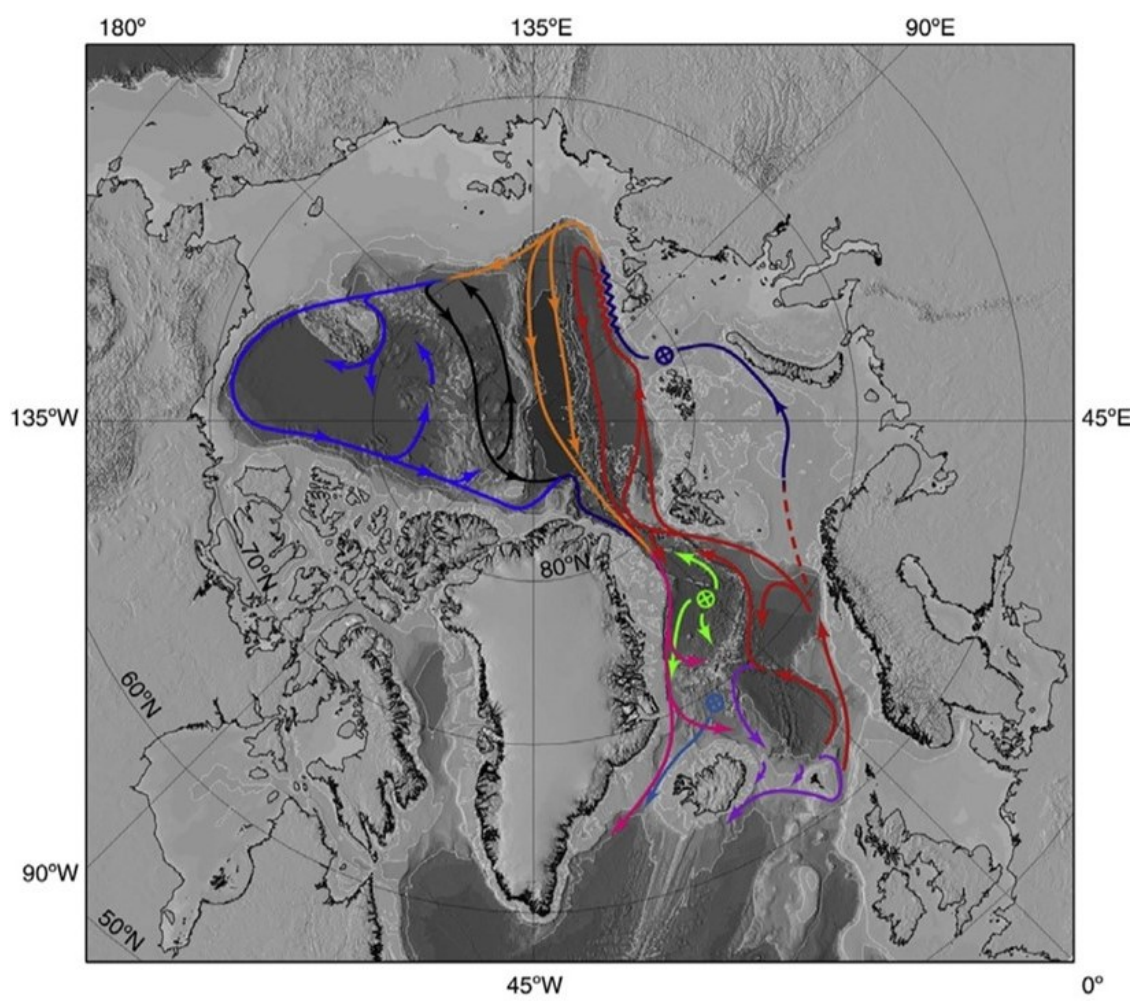

Figure 1-1: A simplified, time-mean depiction of the AW circulation in the Nordic Seas and Arctic Ocean inferred from sparse hydrographic observations. AW enters the AO through Fram Strait and the Barents Sea. The two branches meet in the St. Anna Trench as they circulate cyclonically in the AO. Bifurcations of the AW circumpolar boundary current occur at each ridge. Image from Mauritzen et al., 2013 [1] which was adapted from Rudels et al., $2012[2]$.

The Fram Strait and Barents Sea AW branches meet in the St. Anna Trough north of the Barents Sea. This convergence displaces the Fram Strait Branch offshore from the Barents Sea Branch. The two waters interleave as the less saline, cooler Barents Sea Branch overlies the Fram Strait Branch [5, 9]. In the Laptev Sea, freshwater runoff from the Eurasian continent overruns the AW and occupies the upper portion of the water column (the Surface Layer). This freshwater input increases stratification and inhibits winter convection in the Polar Mixed Layer (PML) from reaching the depths of the AW. With increasing distance from the AO inflow passages, the temperature maximum is deepened to depths of 200-400 m. Thus, the AW becomes largely insulated from the atmosphere and mixing induced by processes such as double diffusion, internal waves or eddies are the principal mechanism by which AW interacts with adjacent water layers [11].

The boundary current has been inferred to remain adjacent to the the continental shelf as it traverses cyclonically (counter-clockwise) around the AO with several bifurcations $[1,9]$. 
At the Nansen-Gakkel Ridge, it is thought that some AW, primarily from Fram Strait, returns along the ridge [12]. Other studies question the existence of a return flow along this ridge due to the a lack of a warm AW core at the bathymetric feature and instead postulate that heat is spread into the Nansen Basin interior by intrusive double-diffusive convection starting at Fram Strait $[13,14]$. A bifurcation at the Lomonosov Ridge is thought to produce a return flow of AW along the ridge directed toward Greenland, which in turn contributes heat to the interior of the Amundsen Basin, while the balance of AW is believed to continue to along the continental slope into the Makarov Basin.

The AW is a reservoir of heat at depths of $100-500 \mathrm{~m}$ in the AO. Model studies suggest a vertical ocean heat flux of $2 \mathrm{~W} / \mathrm{m}^{2}$ is required for the AO sea ice cover to remain in longterm steady-state [15]. If the stratification or mixing intensity in the $\mathrm{AO}$ were to change such that some of this heat was able to reach the surface, reductions in sea ice would occur. Increasing atmospheric temperatures are understood to be a major cause of sea ice loss [16], but warming AW and its effects have been a recent area of focus [4, 10, 17]. Warming in the northern Barents Sea is linked to decreasing Arctic sea-ice import into the region which reduces the freshwater forcing in the Surface Layer, decreases the stratification, and increases vertical heat and salt fluxes from below [10]. Downstream, the "Atlantification" of the eastern Eurasian Basin, marked by decreased stratification caused by reduced sea ice, a weakened halocline, and shoaling of upper AW depths, has caused increased ventilation and reductions in sea ice [4].

While the temporal and spatial coverage of observations in the Arctic has increased due to advanced engineering and technology, a more complete understanding of the AW circulation and properties can be obtained using numerical models to fill observational gaps. A state-of-the-art coupled ocean-sea ice state estimate, the Arctic Subpolar gyre sTate Estimate (ASTE), uses the governing equations in a numerical model and observations to constrain its parameters to create a best-estimate of various AO variables. This study will be the first to analyze the AW Layer in ASTE to investigate its time-mean circulation and temporal variation across the $\mathrm{AO}$ and compare and contrast output with observations. While ASTE uses observations to develop a physically consistent circulation, the solution is temporally and spatially imperfect. This study will qualitatively and quantitatively describe AW differences between observations and ASTE to further the understanding of where model adjustments are needed as well as possible causes. 
Chapter 1 of this thesis summarizes accomplished research in the subject area as well as its importance to the Arctic environment. Descriptions of the data, output and computational methods utilized in this investigation are provided in Chapter 2. Chapter 3 presents the significant results of this investigation. Chapter 4 summarizes the significant contributions of this research to the broader scope of the AO and global ocean circulation and suggests future work building on these conclusions.

\subsection{ASTE Background}

Monthly mean ASTE output are analyzed in this study to better understand the Arctic Ocean circulation and the processes influencing the AW Layer.

ASTE is a regional, medium-resolution coupled ocean-sea ice state estimate and is obtained using the Estimation of the Circulation and Climate of the Ocean (ECCO) state estimation framework $[18,19]$. The ocean component of ASTE is based on the Massachusetts Institute of Technology General Circulation Model (MITgcm) [20]. Dynamics and thermodynamics of sea ice are simulated using the MITgcm's sea ice package [21, 22, 23].

ASTE uses a latitude-longitude-polar-cap (LLC) grid, specifically LLC-270, with a horizontal resolution of approximately $14 \mathrm{~km}$ in the Arctic. The domain covers the entire Arctic, Canadian Arctic Archipelago, all adjacent seas (Bering, Kara, Barents, GreenlandIceland-Norwegian, and Labrador), and the entire North Atlantic. Open boundaries exist at $32.5^{\circ} \mathrm{S}$ in the Atlantic, $47.5^{\circ} \mathrm{N}$ in the Pacific and at the Strait of Gibraltar. Conditions at the open boundaries in the Atlantic and North Pacific are taken from ECCOv4r3 https://ecco-group.org/products.htm. Vertically, ASTE is composed of 50 unevenly spaced levels with the thinnest layer $(10 \mathrm{~m})$ at the surface and the thickest $(500 \mathrm{~m})$ at $5000 \mathrm{~m}$. The bathymetry is merged from the International Bathymetric Chart of the Arctic Ocean (IBCAO) [24] for areas poleward of $60^{\circ} \mathrm{N}$ and Smith and Sandwell version 14.1 [25] south of $60^{\circ} \mathrm{N}$, with a blending of these two sources within $100 \mathrm{~km}$ of $60^{\circ} \mathrm{N}$. Depths of geographic features such as Barrow Canyon, Florida Straits, Greenland-Iceland-Faroe-Scotland Ridge, the Aleutians, and Strait of Gibraltar were adjusted as needed to be consistent with observed depths and ensure consistency of transports and circulations in the state estimate with observations.

Surface forcings come from the adjusted 3-hourly Japanese Reanalysis (JRA-55). Fresh- 
water fluxes for estuaries were taken from Regional, Electronic, Hydrographic Data Network for the Arctic Region (R-ArcticNET) [26, 27]. Initial conditions are derived from a data-constrained spin-up, that utilized the Pan-Arctic Ice Ocean Modeling and Assimilation System (PIOMAS) [28] sea ice conditions for January 2002 and the (now-superseded) World Ocean Atlas 2013 version 1 (https://www.nodc.noaa.gov/0C5/woa13/) as initial hydrography. Horizontal stirring fields (expressed as isopycnal diffusivities and bolus velocities) and vertical diffusion coefficients are optimized from initial guesses taken from published literature as specified in [19].

Data constraints in ASTE include a full suite of satellite and in situ observations from the ECCOv4r3 database (sea surface temperature, sea level anomalies, mean dynamic topography, Argo floats, ship-based CTD, moorings) [29]. In addition, for high latitudes, satellite-derived sea ice thickness and concentration data, in situ hydrographic measurements from ITPs and ship-based CTDs, and mooring observations at important gateways are used. A full list of observations is provided in [19].

ASTE is fit to observations through a gradient-based iterative least-square minimization of the model-data misfit that takes into account data and model uncertainties $[19,30]$. In addition, using the method of Lagrange Multipliers, the underlying model physics are strictly enforced. By strictly obeying the conservation laws of momentum and tracers, ASTE is physically consistent and can be used for circulation and budget analyses as there are no artificial fluxes or unaccounted artificial nudging terms. The optimization period of ASTE is 2002-2017.

Uncertain model variables and parameters are adjusted during optimization. The ASTE control space is comprised of the initial ocean hydrography, time-independent spatially varying model mixing parameters (horizontal stirring and vertical diffusivities), and the timevarying atmospheric surface forcing. A priori uncertainties based on previously published work ensure that the control space adjustments are within physically reasonable limits.

ASTE Release 1 (ASTE R1) was obtained after 62 iterations. The input optimized controlled and output fields are made publicly available at the UT-Austin ECCO data portal at https://web.corral.tacc.utexas.edu/OceanProjects/ASTE/Release1/ in both NETCDF and raw binary formats.

In this study, monthly mean velocity components in original C-grid locations were centered to be co-located with scalars (e.g. temperature and salinity) at the grid center lo- 
cations. The output from January 2002 through 2017 is concurrent with the observation database for this study. Output from ASTE R1 will be referred to as ASTE output for this study.

\subsection{Background on ITPs and CTDs}

Observations in the AO have been historically limited due to its challenging environment. Some of the first hydrographic observations were made during Nansen's North Pole expedition in the Fram. The Fram was engineered to withstand the pressures of being frozen and subsequently fastened into sea ice near Eurasia for a multi-year transport in the Transpolar Drift toward the North Pole before escaping the ice and exiting the AO near Fram Strait. Although the expedition did not reach the pole, it did advance our understanding of the AO and notably, documented a warm, salty water mass at mid depth, which Nansen correctly asserted, "must originate from the Atlantic Ocean" [31], below the cold, relatively fresh upper ocean.

Since Nansen's expedition, oceanography has benefited from advances in engineering and technology. Autonomous instruments such as Argo floats and AUVs have been developed to collect hydrographic profiles across the world's oceans, but like most ship-based CTDs, the instruments have been generally restricted to ice-free conditions. While some icebreaker and air supported ice camp work has been conducted, sea ice has greatly restricted AO observations. Ice Tethered Profilers (ITPs) were developed to operate in an unstable, icecovered environment to obtain hydrographic profiles in the AO and were first deployed in $2004[32,33]$. A surface package sits on top of the ice as an anchor and communications device to relay data from a tethered profiler below the ice to shore. The tether length is approximately $800 \mathrm{~m}$ which sets the deepest observational limit. Upper water column measurements begin at approximately $5 \mathrm{~m}$ depth to help prevent the profiler from being damaged due to subsurface ice. The profiler measures temperature, salinity, and pressure using a SBE 41-CP CTD sampling at $1 \mathrm{~Hz}$ frequency with a one-way vertical profile typically conducted every six hours. The profile speed is $25 \mathrm{~cm} / \mathrm{s}$ which results in a $0.25-\mathrm{m}$ raw data resolution. This study leverages processed in situ ITP data in addition to available ship and ice camp derived CTDs, as discussed in Section 2.1, obtained during the ASTE analysis period to qualitatively and quantitatively compare AW Layer properties in observations to 
ASTE output. 


\section{Chapter 2}

\section{Methods}

The methods used to analyze the AW Layer in this study are presented in this chapter. How the observations were obtained to build the database are presented first. Next, the partitioning scheme of the AO into smaller subbasins is discussed with the creation of boundary current contours based on this partitioning explained in the next section. The sections which follow discuss the selection and process for determining the depth of the AW Layer bounding isopycnals, the equations for calculating AW Layer ocean heat content and average AW Layer potential temperature, the processes used to calculate transport streamfunction, and the time-mean AW Layer streamlines and properties. The final section discusses how observations are associated and compared with ASTE output.

\section{$2.1 \quad$ CTDs and ITPs}

ITP data were acquired from the publicly available archive hosted by the Woods Hole Oceanographic Institution (WHOI) https ://www . whoi .edu/page.do?pid=20781. This study uses Level 3 processed data in which sensor corrections are applied, corrupt data are removed, conductivity is calibrated profile-by-profile based on deep water references, outliers are screened, and the data are binned at 1-dbar vertical resolution. Further information regarding the post-processing of ITP data is detailed in "ITP Data Processing Procedures" available on the WHOI ITP webpage. The database contains 49,116 observations from a total of 62 ITP systems.

Ship and ice-camp CTD data were acquired via the World Ocean Database 2018 archive (WOD18) which is a product of the National Centers for Environmental Information (NCEI) 
and an International Oceanographic Data and Information Exchange (IODE) project. All available CTD profiles poleward of $65^{\circ} \mathrm{N}$ from 2002 through 2018 were downloaded. CTDs outside the $\mathrm{AO}$ between $65^{\circ} \mathrm{N}$ and $77^{\circ} \mathrm{N}$ from $112^{\circ} \mathrm{W}$ to $50^{\circ} \mathrm{E}$ were removed using Ocean Data View (ODV) [34]. A total of 15,307 CTDs comprise the WOD18 CTD database for this study.

Additional CTD profiles were obtained from the Beaufort Gyre Exploration Project which maintains the Beaufort Gyre Observing System (BGOS). Hydrographic profiles collected after 2008 were not included in the WOD18 database query and were therefore separately obtained for this study. This provided 607 additional hydrographic profiles.

\subsection{Basin Assignment}

To quantify spatial variations in AW properties, the AO is split into subbasins using ASTE fields. The $\mathrm{AO}$ is first divided into basins using the three main ridges as the borders of each basin. The Nansen-Gakkel Ridge separates the Nansen Basin from the Amundsen Basin. The Lomonosov Ridge divides the Amundsen Basin and the Makarov Basin. The Mendeleyev Ridge separates the Makarov Basin and Canada Basin. These ridges along with other geographic and bathymetric features are shown in Figure 2-1. 


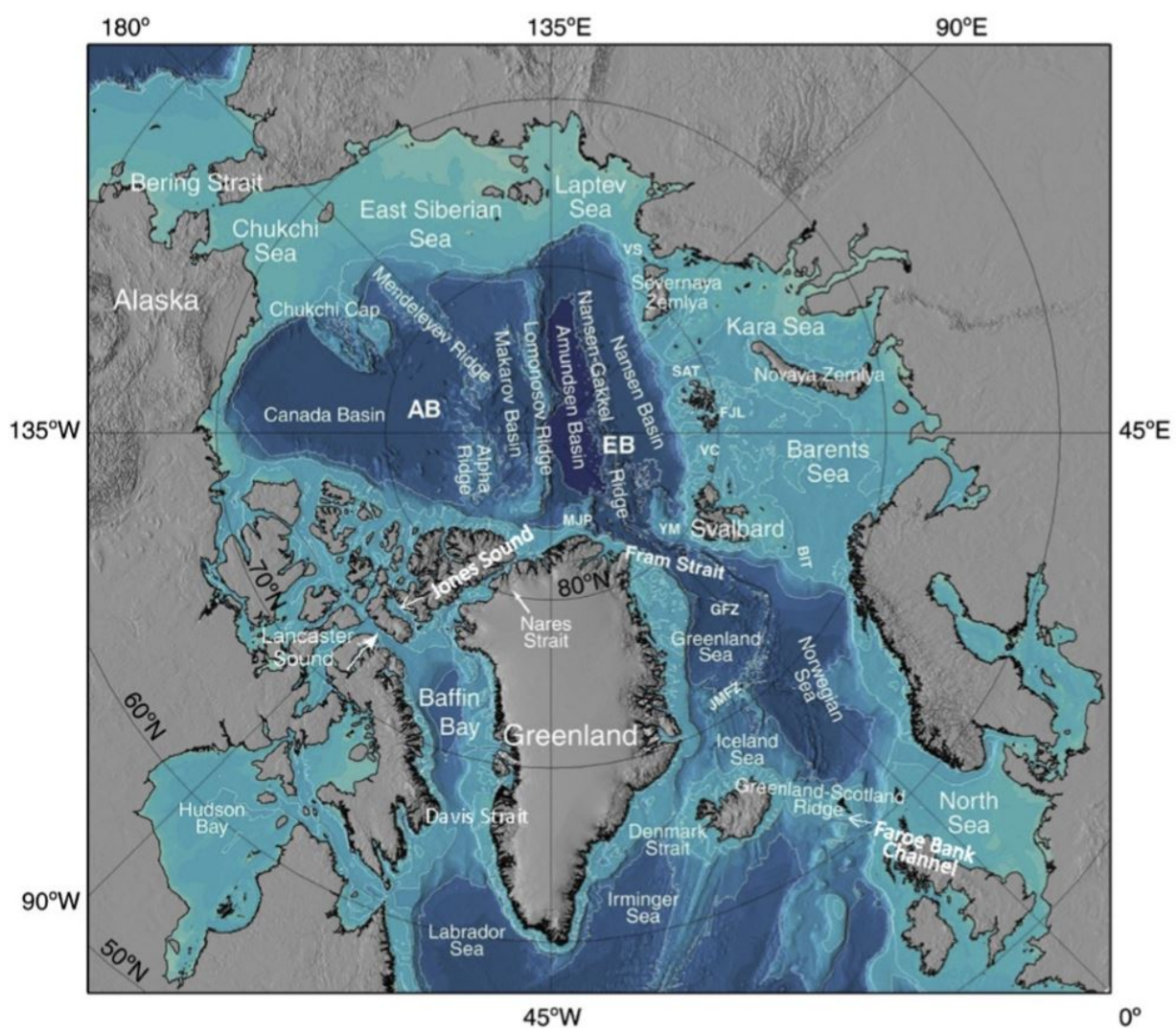

Figure 2-1: Major geographic and bathymetric features in the AO, Nordic Seas and North Atlantic. Image is from Mauritzen et al., 2013 [1] which was adapted from Rudels et al., 2012 [2].

Each AO basin was subsequently divided in half to separately analyze AW properties within the Eurasian and North American sectors of the Arctic. The boundary between the two sides was set along $60^{\circ} \mathrm{E}$ from $80^{\circ} \mathrm{N}$ (intersecting Franz Josef Land) to the pole and along $150^{\circ} \mathrm{W}$ from the northern coast of Alaska to the pole.

The half basins were further partitioned based on water depth and maximum potential density within the water column. The three subsectors are named: Shelf, Circumpolar, and Mid. Shelf sub regions are defined by water depths less than $100 \mathrm{~m}$. Circumpolar regions are within $100 \mathrm{~km}$ of the $100 \mathrm{~m}$ depth contour or contain profiles with a maximum potential density relative to 200 dbar of less than $1028.9 \mathrm{~kg} / \mathrm{m}^{3}$ in any monthly mean ASTE output. Mid subbasins are the remaining regions more than $100 \mathrm{~km}$ from the $100 \mathrm{~m}$ depth contour that always contain maximum potential densities greater than or equal to $1028.9 \mathrm{~kg} / \mathrm{m}^{3}$ relative to 200 dbar in monthly mean ASTE output (see Section 2.4). 
The entrance and exit of the AO in Fram Strait was defined by mooring locations from the Fram Strait Arctic Outflow Observatory jointly operated by the Norwegian Polar Institute and the Alfred Wegener Institute. This array is designed to measure inflow from the Atlantic near Svalbard and outflow from the Arctic near Greenland. From Svalbard east to Severnaya Zemlya, $80^{\circ} \mathrm{N}$ separates the Barents Sea from the AO. On the Pacific side, $70^{\circ} \mathrm{N}$ is taken as the boundary between the Arctic Ocean and the Subpolar North Pacific.

Since the Nansen-Gakkel Ridge bisects Svalbard, the shelf and circumpolar regions of the North American side of the Amundsen Basin are further partitioned into a Svalbard side and Greenland side. The AW which entered the AO near Svalbard is warm and salty while the outflow on the Greenland side is cooler and fresher. To separate the two distinct water types, the regions needed to be split. Similarly, the mid basin for the North American side of the Amundsen Basin is split at $81^{\circ} \mathrm{N}$ to separate the section within Fram Strait, which contains a mix of recirculating AW that just entered the strait and departing transformed $\mathrm{AO}$ water, from the rest of the mid basin.

The culmination of this AO partitioning is presented in Figure 2-2. The shelf regions are not indicated since they were not used to investigate the AW Layer in this study. The subbasin acronyms listed in the figure caption are used to identify individual subbasins in this study. 


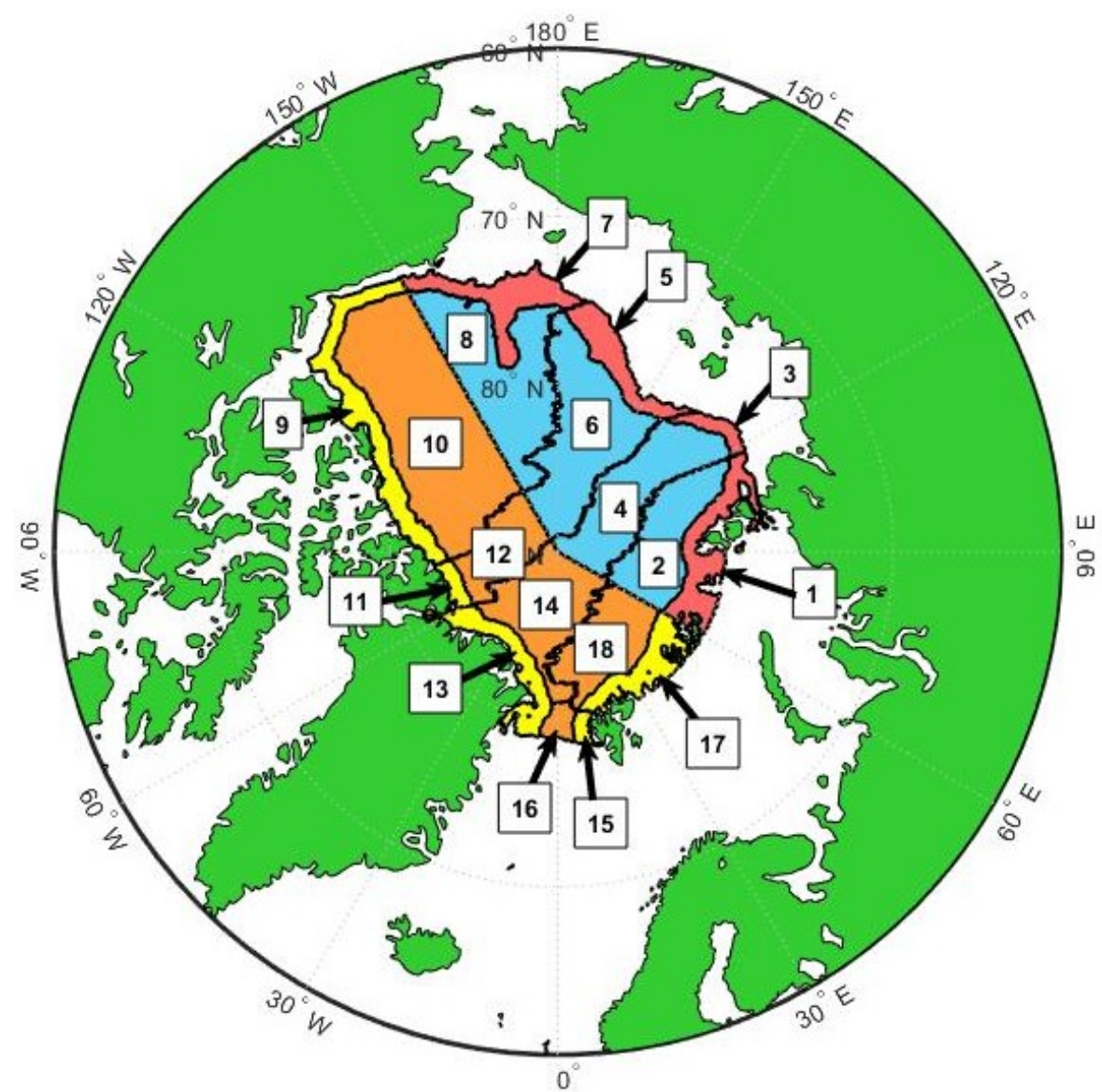

Figure 2-2: The AO partitioning scheme developed to examine AW properties. On the Eurasian side of each basin, circumpolar subbasins are colored red and mid subbasins are blue. On the North American side, circumpolar subbasins are colored yellow and mid subbasin are orange. Numbered subbasins are as follows: 1. Eurasian Circumpolar Nansen Basin (ECNB), 2. Eurasian Mid Nansen Basin (EMNB), 3. Eurasian Circumpolar Amundsen Basin (ECAB), 4. Eurasian Mid Amundsen Basin (EMAB), 5. Eurasian Circumpolar Makarov Basin (ECMB), 6. Eurasian Mid Makarav Basin (EMMB), 7. Eurasian Circumpolar Canada Basin (ECCB), 8. Eurasian Mid Canada Basin (EMCB), 9. North American Circumpolar Canada Basin (NCCB), 10. North American Mid Canada Basin (NMCB), 11. North American Circumpolar Makarov Basin (NCMB), 12. North American Mid Makarov Basin (NMMB), 13. North American Greenland Circumpolar Amundsen Basin (NGCAB), 14. North American Poleward Mid Amundsen Basin (NPMAB), 15. North American Svalbard Circumpolar Amundsen Basin Svalbard (NSCAB), 16. North American Fram Mid Amundsen Basin (NFMAB), 17. North American Circumpolar Nansen Basin (NCNB), 18. North American Mid Nansen Basin (NMNB). 


\subsection{Atlantic Water Boundary Current Contours}

Two contours are produced to investigate the AW circulation and properties along major AW pathways: the Lomonosov Boundary Current and the Circumpolar Boundary Current. The Lomonosov Boundary Current contour begins at Fram Strait, turns north of Svalbard and follows the continental shelf cyclonically through the Laptev Sea, turns to parallel the Lomonosov Ridge and follows the continental shelf south offshore of Greenland. This contour is produced using the boundary of the circumpolar and mid subbasins in Figure 2-2 and a $100 \mathrm{~km}$ buffer along the Lomonosov Ridge. The resulting Lomonosov Boundary Current contour is shown in Figure 2-3. Letters on the contour identify the beginning ('A'), subbasin transitions ('B' - 'F'), and end ' $G$ ' of the contour.

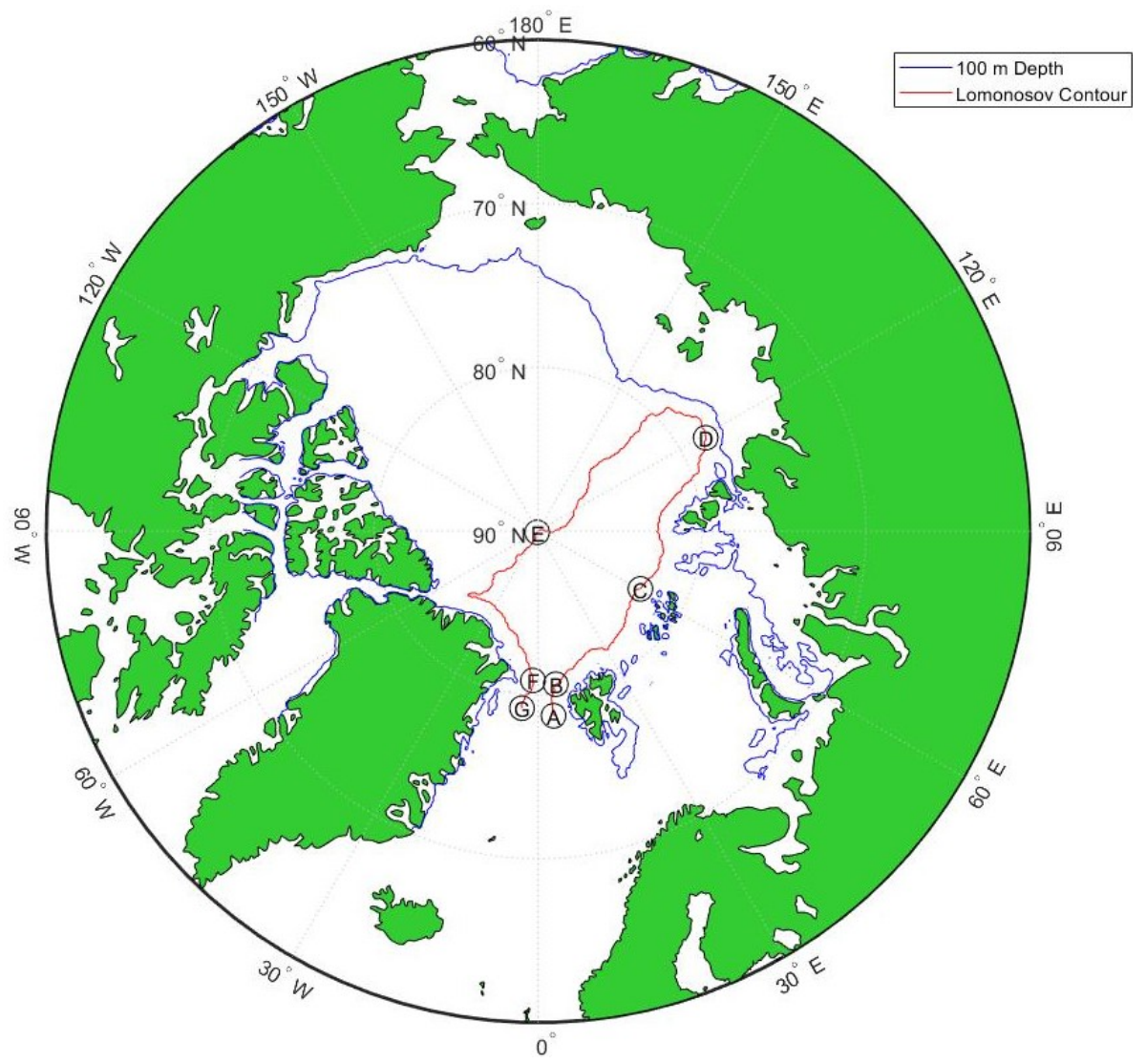

Figure 2-3: The Lomonosov Boundary Current contour is depicted in red. The contour is produced using the circumpolar and mid subbasin boundaries depicted in Figure 2-2 and a $100 \mathrm{~km}$ buffer region along the Lomonosov Ridge. Letters mark the beginning and end of the contour as well as subbasin transitions. The blue contour is the $100 \mathrm{~m}$ isobath. 
Another contour is created to describe the AW following the Arctic Circumpolar Boundary Current around the entire AO as shown in Figure 2-4. Similar to the contour produced for the Lomonosov Boundary Current, this contour begins at Fram Strait and follows the continental shelf cyclonically through the Laptev Sea, but instead of turning at the Lomonosov Ridge, the Circumpolar Boundary Current continues across the ridge following the continental shelf along the boundary of the circumpolar and mid subbasins. Since both boundary current contours are concurrent from Fram Strait through the Laptev Sea, letters 'A' through 'D' are shared locations. The two contours diverge between subbasin transitions ' $\mathrm{D}$ ' and 'E'. Location 'E' is where the Circumpolar Boundary Current crosses the Lomonosov Ridge into the Makarov Basin. Letters ' $F$ ' through 'J' along the circumpolar boundary current contour identify subbasin transitions as the contour continues around the AO cyclonically. The contour concludes at location 'K' east of Greenland in Fram Strait.

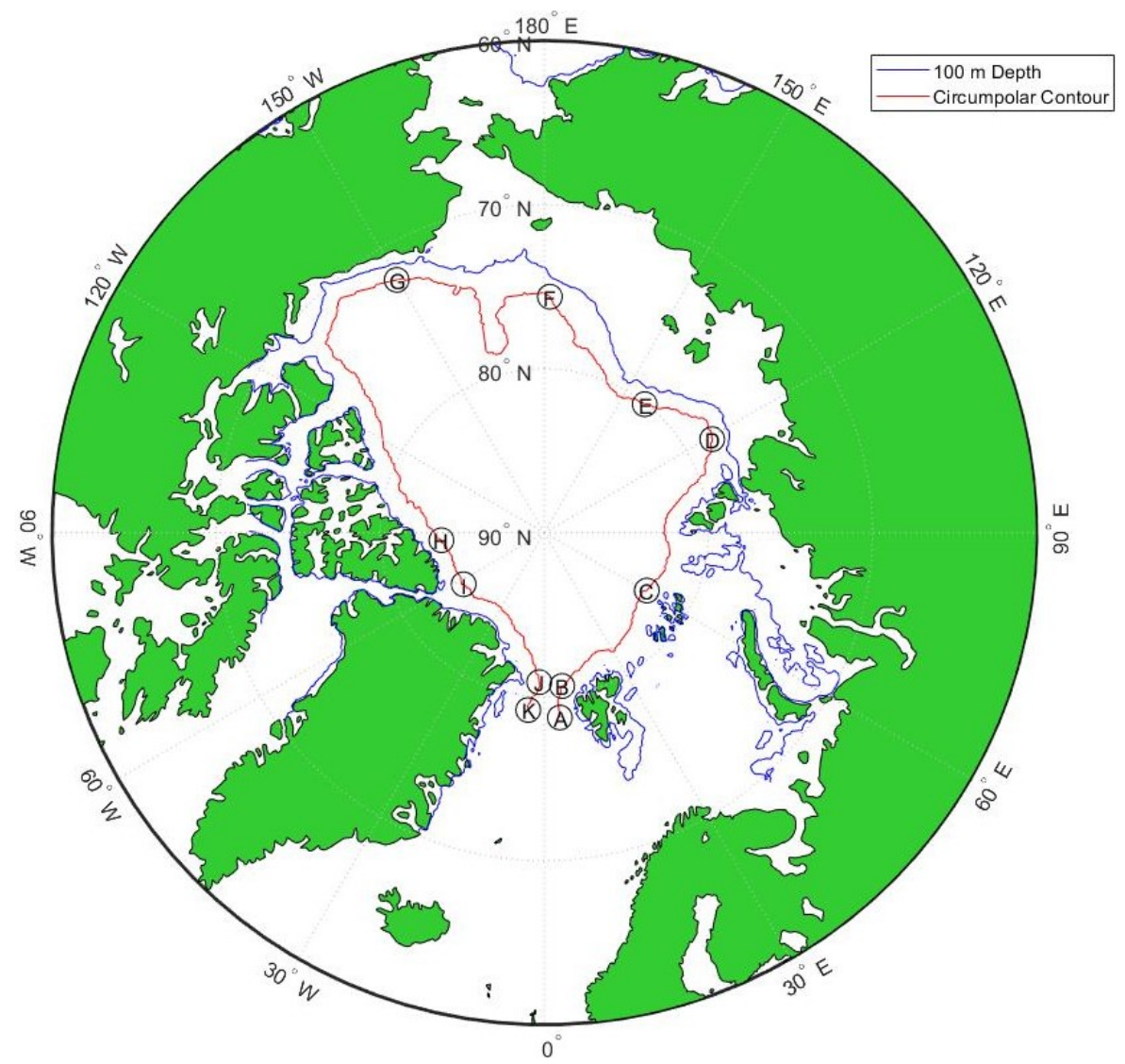

Figure 2-4: The Circumpolar Boundary Current contour is depicted in red which follows the subbasin boundaries depicted in Figure 2-2. Letters mark the beginning and end of the contour as well as subbasin transitions. The blue contour is the $100 \mathrm{~m}$ isobath. 


\subsection{Atlantic Water Bounding Isopycnals}

For this study, isopycnals are used to bound the AW Layer throughout the AO. These boundaries are utilized to calculate and analyze AW Layer properties. Figure 2-5 depicts the two bounding isopycnals, $1028.2 \mathrm{~kg} / \mathrm{m}^{3}$ and $1028.9 \mathrm{~kg} / \mathrm{m}^{3}$, against mean potential density vs. potential temperature profiles for Eurasian Mid Nansen Basin (EMNB in Figure 2-2) and the North American Mid Canada Basin (NMCB in Figure 2-2). The potential temperature profiles are averaged on potential density surfaces using all available observations (CTDs and ITPs) in the database for the specified subbasins. The reference pressure for potential density is $200 \mathrm{dbar}$ for this study. This reference pressure was selected since AW is generally observed around this depth in the AO. The upper AW bounding isopycnal, $1028.2 \mathrm{~kg} / \mathrm{m}^{3}$, was selected as it lies below the Pacific Winter Water which is identified as a potential temperature minimum above the AW Layer maximum temperature. In the NMCB subbasin mean profile, the potential temperature minimum occurs at $1027.57 \mathrm{~kg} / \mathrm{m}^{3}$. Since ITP depths are limited to the length of the tether, the ITP profile maximum potential density is limited as well. Thus, an isopycnal which was contained in a majority of observations was judged best to support an AW Layer analysis against ASTE output. The lower AW bounding isopycnal, $1028.9 \mathrm{~kg} / \mathrm{m}^{3}$, was selected as a potential density level which was contained in approximately $75 \%$ of available observations (CTDs and ITPs) in the NMCB subbasin. The bounding isopycnals encompass the AW temperature maximum in the mean observation potential temperature profiles closest and furthest from the areas of AW inflow to the AO. The mean potential temperature profile for the EMNB subbasin, which contains AW from both Fram Strait and the Barents Sea, contains an AW potential temperature maximum $\left(1.60^{\circ} \mathrm{C}\right)$ at $1028.85 \mathrm{~kg} / \mathrm{m}^{3}$ while the NMCB subbasin potential temperature maximum $\left(0.66^{\circ} \mathrm{C}\right)$ occurs at $1028.86 \mathrm{~kg} / \mathrm{m}^{3}$. 


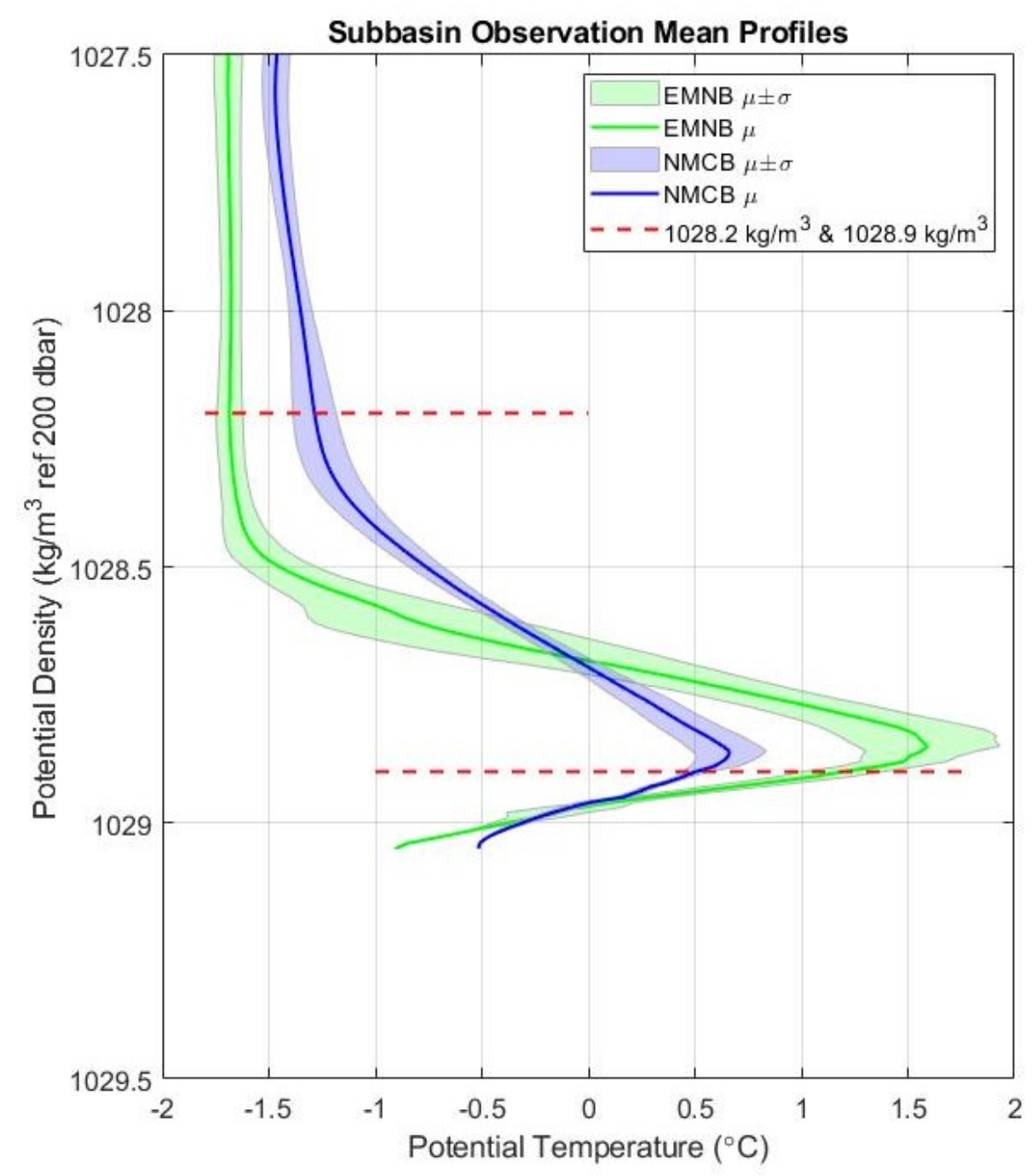

Figure 2-5: The AW Layer bounding isopycnals for this study plotted on mean potential density referenced to 200 dbar versus mean potential temperature referenced to the 0 dbar profiles for the EMNB (green) and NMCB (blue) subbasins with one standard deviation about the mean shaded. Subbasin depictions and acronyms are provided in Figure 2-2.

The mean profiles are also plotted in Figure 2-6 with depth as the vertical coordinate rather than potential density. The mean (dashed) and standard deviation (dotted) of the bounding AW isopycnal depths are plotted for each profile. Within each subbasin, the depth of the upper bounding isopycnal $\left(1028.2 \mathrm{~kg} / \mathrm{m}^{3}\right)$ varies less than the lower isopycnal $\left(1028.9 \mathrm{~kg} / \mathrm{m}^{3}\right)$ likely due to increased stratification higher in the water column as evident in Figure 2-5. Also evident is the erosion of the AW temperature maximum from the Nansen Basin to the opposite side of the AO in the Canada Basin. The temperature minimum and maximum associated with the Pacific Winter Water and Pacific Summer Water layers respectively overlie the AW Layer in the NMCB profile. 


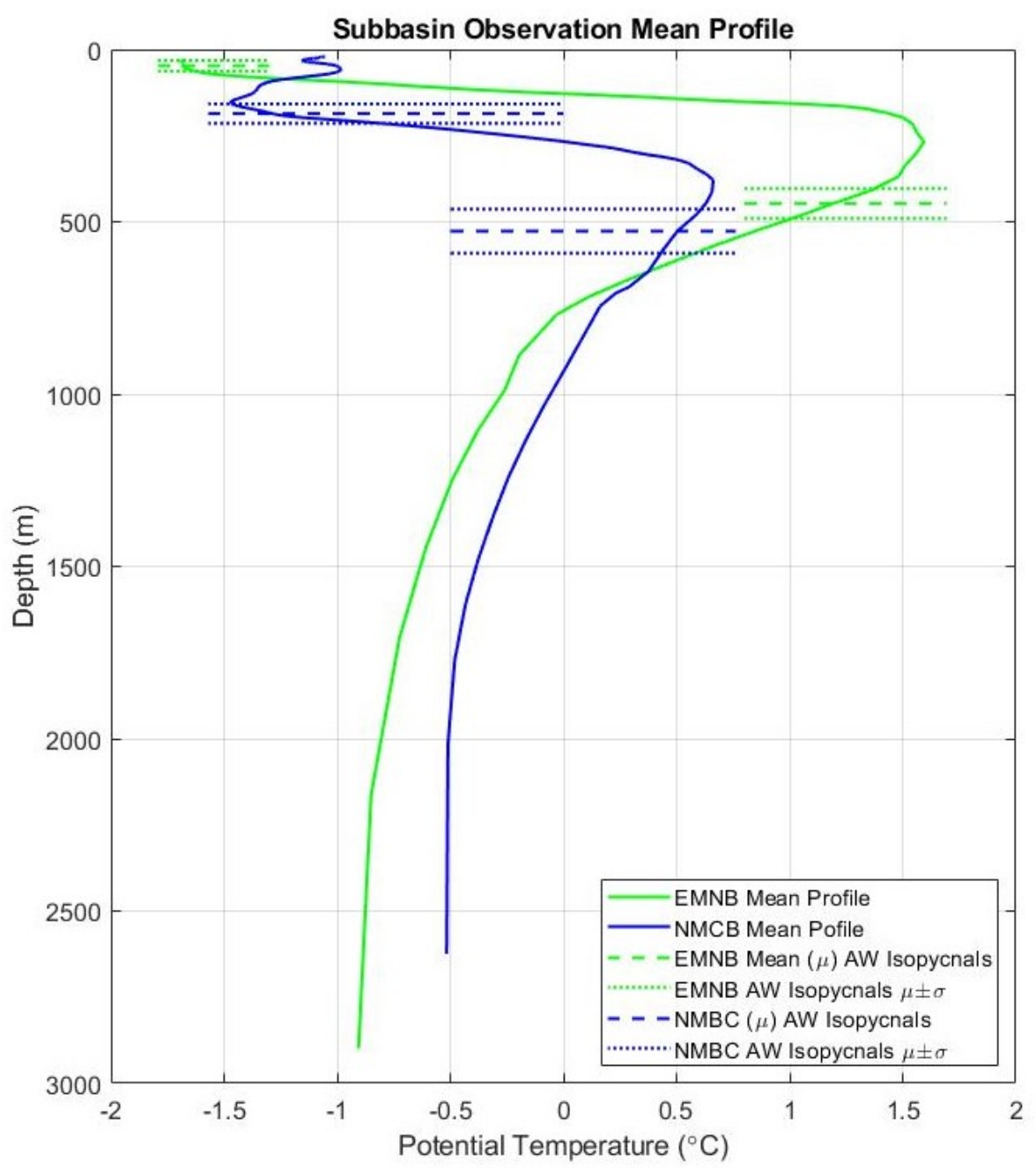

Figure 2-6: The mean depth versus potential temperature profiles for the EMNB (green) and NMCB (blue) subbasins. The mean depths (dashed) and standard deviation (dotted) of the bounding AW isopycnals are plotted in the same color as their associated subbasin profile with the $1028.2 \mathrm{~kg} / \mathrm{m}^{3}$ isopycnal located higher in the water column than 1028.9 $\mathrm{kg} / \mathrm{m}^{3}$.

Figure 2-7 displays the mean and standard deviation of pressure for the potential densities surrounding the AW Layer. The standard deviations of pressure on the potential density surfaces are similar for both basins implying that eddy and interannual variability of density surface depths are as well despite the differences in depths. 


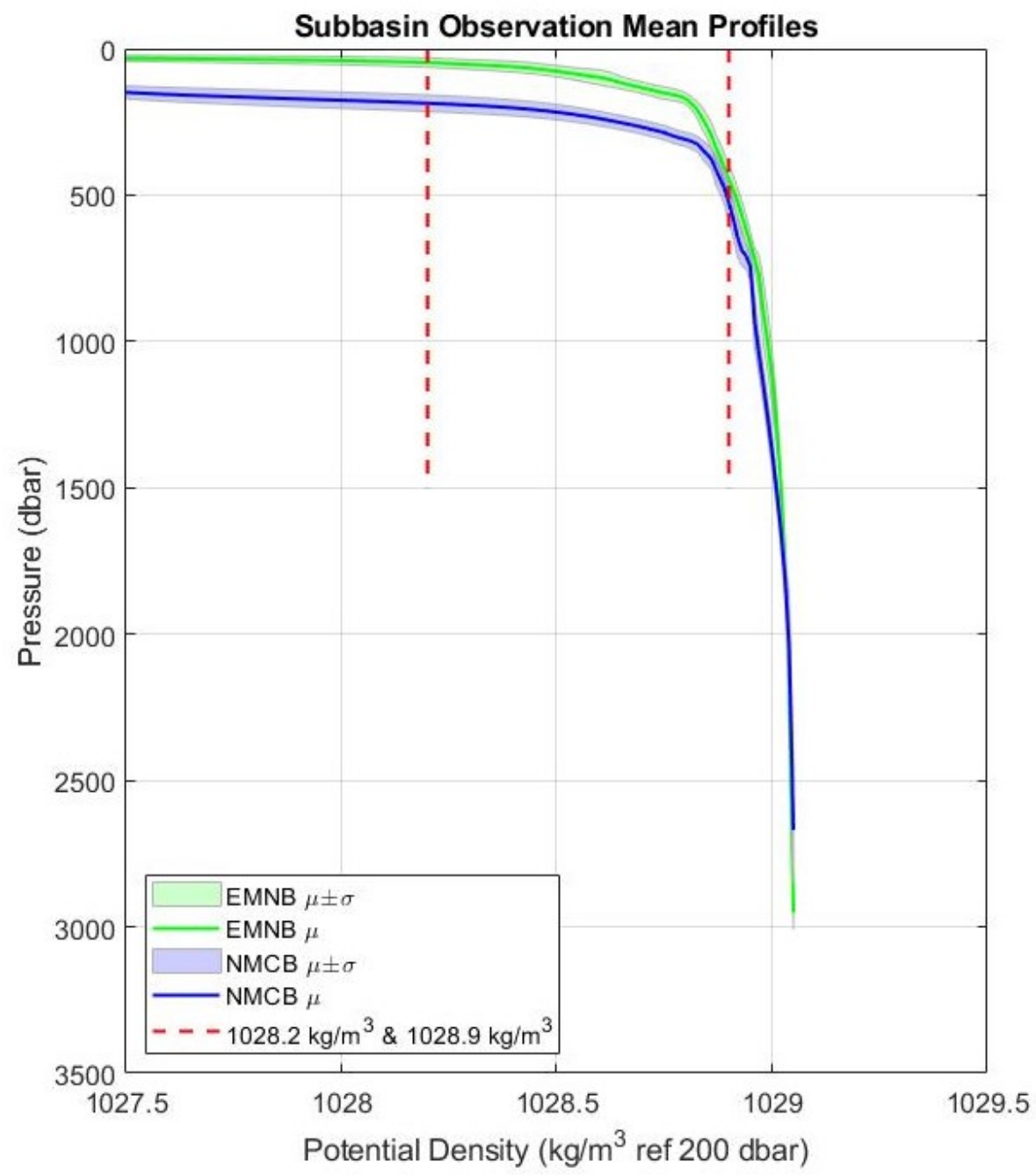

Figure 2-7: The AW Layer bounding isopycnals for this study plotted against mean pressure versus potential density profiles for the EMNB (green) and NMCB (blue) subbasins with one standard deviation about the mean shaded.

\subsection{Ocean Heat Content}

Ocean Heat Content (OHC) for the AW Layer at specified locations within the Arctic is calculated using Equation 2.1.

$$
H_{c}=\int_{z_{b}}^{z_{t}} \rho(z) c_{p}(z) \Theta(z) d z
$$

In Equation 2.1, $\mathrm{H}_{c}$ is heat content $\left(\mathrm{J} / \mathrm{m}^{2}\right), \mathrm{z}_{b}$ is the bottom layer depth, $\mathrm{z}_{t}$ is the top layer depth, $\rho$ is seawater density $\left(\mathrm{kg} / \mathrm{m}^{3}\right), \mathrm{c}_{p}$ is the heat capacity of seawater $\left(\mathrm{J} \mathrm{kg}^{-1} \mathrm{~K}^{-1}\right)$ and $\Theta$ is potential temperature $\left({ }^{\circ} \mathrm{C}\right)$. The average layer potential temperature $\left(\Theta_{a v}\right)$ can be 
calculated from Equation 2.2.

$$
\Theta_{a v}=\frac{H_{c}}{\int_{z_{b}}^{z_{t}} \rho(z) c_{p}(z) d z}
$$

For AW Layer calculations, the lower and upper limits of integration $\left(z_{b}\right)$ and $\left(z_{t}\right)$ are the depths of the AW bounding isopycnals. Isopycnal depths are found by linearly interpolating isopycnal depths of ASTE output and CTD/ITP observations to potential density surfaces at $0.01 \mathrm{~kg} / \mathrm{m}^{3}$ intervals. We focus our analysis using $\Theta_{a v}$ rather than $\mathrm{OHC}$ since the AW Layer thickness varies in space, which complicates the assessment of regional differences in $\mathrm{OHC}$.

\subsection{Transport Streamfunction}

Calculations for the transport of AW into, within, and out of the Arctic Ocean were made using the time-averaged model $\mathrm{u}$ - and v-components relative to the ASTE grid. The period of time-averaging was from January 2010 to December 2017. The motivation for beginning the averaging time period at January 2010 rather than January 2002 is due to a flow reversal seen in the ASTE output in 2004-2008 which is discussed further in Section 3.3.2. Following the flow reversal, the circulation achieves an approximate steady-state, which permits a best analysis of the time-averaged AW Layer flow. A subset of the model grid that includes $380 \mathrm{x}$-coordinates and $270 \mathrm{y}$-coordinates is shown in Figure 2-8 with bathymetry and land depicted. 


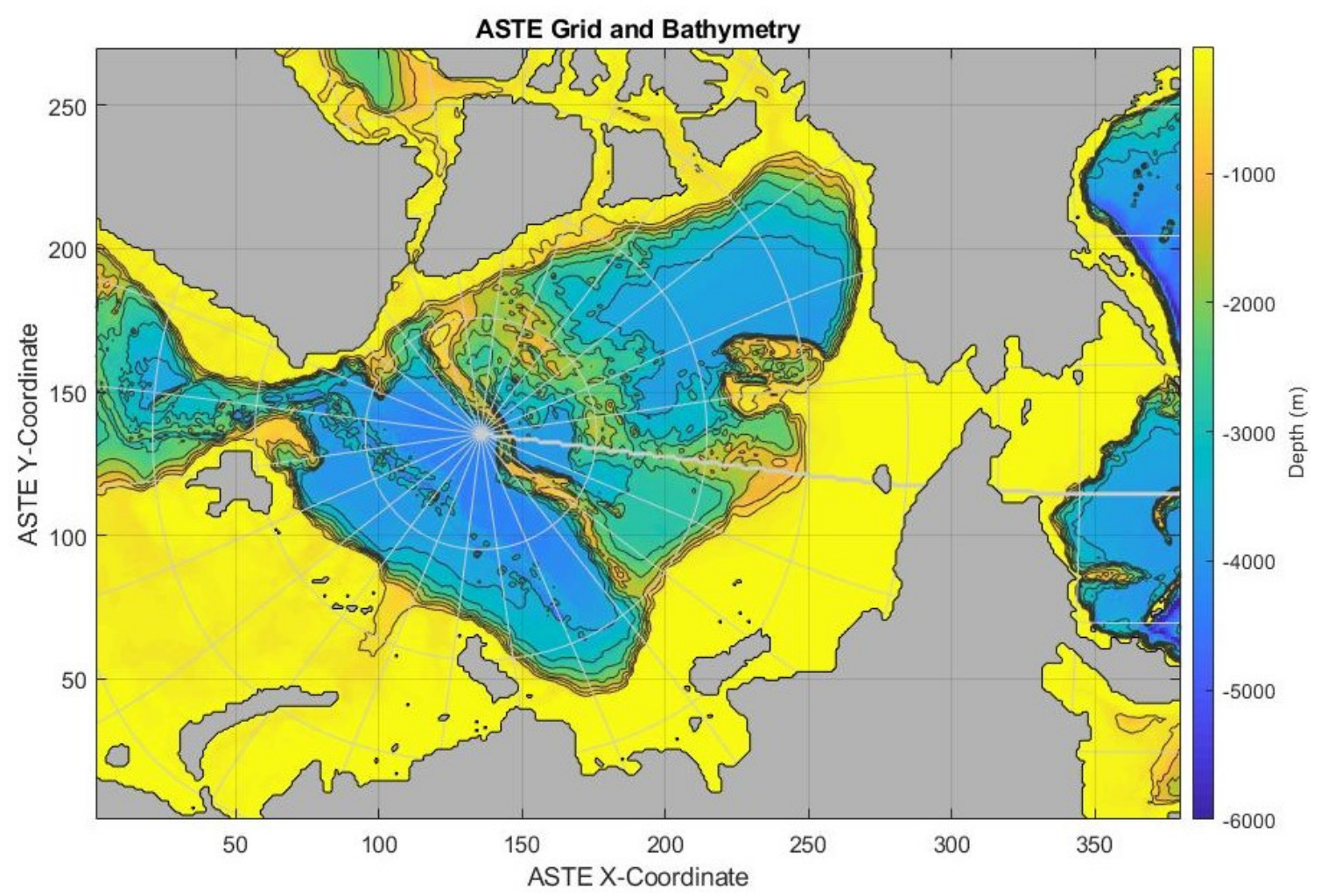

Figure 2-8: The ASTE grid $\mathrm{x}$ - and $\mathrm{y}$-coordinates relative to major geographic features overlaid on bathymetry. Latitude lines are drawn every $5^{\circ}$ and longitude every $15^{\circ}$.

Initial streamfunction estimates were calculated by integrating the $\mathrm{x}$-directed layer transport in the $\mathrm{y}$ - direction along each $\mathrm{x}$-line. The time averaged ASTE AW circulation is horizontally divergent owing to interannual trends in water mass layer volumes and water mass transformation in the AO. In such cases, the transport streamfunction is not formally defined. Therefore a (non-unique) estimate of the horizontally non-divergent flow was also derived. At each $\mathrm{x}$-line an estimated linear transport curve in the $\mathrm{y}$-direction is made from the initial streamfunction estimate. Linear curves begin at zero on the Eurasian coast and end at a value equal to the initial streamfunction on the North American coast. The linear trend is removed so that layer transport values are equal to zero at each coast to isolate the non-divergent part of the flow. This is a non-unique method of depicting the non-divergent component of the AW circulation. The actual model divergent field for the time-mean circulation is noisy at the grid spacing level and indistinguishable from the uniform divergent field assumed in constructing the non-divergent circulation.

The overturning (divergent) component of the flow can be estimated using the full ASTE mean transport fields integrated over a series of adjoining density layers. The overturning 
of three density layers are analyzed: a Surface Layer (potential densities $<1028.2 \mathrm{~kg} / \mathrm{m}^{3}$ ), the AW Layer (potential densities $1028.2 \mathrm{~kg} / \mathrm{m}^{3}$ to $1028.9 \mathrm{~kg} / \mathrm{m}^{3}$ ) and a Bottom Layer (potential densities $>1028.9 \mathrm{~kg} / \mathrm{m}^{3}$ ).

\subsection{Time-Mean Atlantic Water Layer Streamlines and Prop- erties}

In parallel with the transport calculations, to better visualize the time-mean AW flow field in the AO, the mean AW velocity between the AW bounding isopycnals is calculated for each grid cell in the AO where both bounding isopycnals exist in each monthly file (e.g. excluding grid cells where the upper isopycnal, $1028.2 \mathrm{~kg} / \mathrm{m}^{3}$, has outcropped or the lower isopycnal, $1028.9 \mathrm{~kg} / \mathrm{m}^{3}$, doesn't exist). The model velocity components are linearly interpolated from the grid cell centers at one meter depth intervals. The mean velocity components are computed between the depths of the lower and upper bounding AW isopycnals using the one meter depth interval velocities. The time-mean of these velocity components from January 2010 to December 2017 is then calculated. Using MATLAB's "streamslice" function, streamlines are plotted which follow velocity vectors to view generalized circulation and areas of confluence and diffluence.

Time-mean AW Layer properties (e.g. $\Theta_{a v}$, AW Layer thickness and AW bounding isopycnal depths) in ASTE are calculated only for locations where both bounding AW isopycnals exist within the water column in every monthly output file over the averaging time period.

\subsection{ASTE vs. Observed Atlantic Water Properties}

The AW properties in ASTE are analyzed against observed AW properties in Section 3.4 to see if ASTE faithfully represents the AW Layer in the AO. Since this study uses monthly mean ASTE output, the month the observation occurred is compared to its associated month in ASTE output. Each observation is also compared against ASTE output at the grid cell closest to the observation. Only observations where both AW bounding isopycnals exist within the observed profile and its associated ASTE water column in the monthly mean output are included in this analysis. The observations and model output within the individual subbasins discussed earlier in this chapter are analyzed. The resulting analysis is 
a comparison of local observations in space and time and model fields within $\sim 14 \mathrm{x} 14 \mathrm{~km}$ grid cells averaged over one month. 
THIS PAGE INTENTIONALLY LEFT BLANK 


\section{Chapter 3}

\section{Results}

This chapter describes the AW Layer in ASTE and concludes with a comparison of observed and model AW properties. The time-mean properties of the AW Layer in ASTE are presented before discussing the model time-mean AW circulation. Following these sections, the mean seasonal and interannual variability of the AW circulation in ASTE are discussed. Finally, the spatial and time-varying AW properties in ASTE are presented with a comparison to observed AW properties.

\subsection{Atlantic Water Time-Mean Properties}

The time-averaged, mean AW Layer potential temperature, $\Theta_{a v}$, between the AW bounding isopycnals from January 2010 through December 2017 in ASTE is shown in Figure 3-1. Only subbasin grid locations where both bounding isopycnals exist in every monthly mean file during this time period are plotted; thus accounting for the displayed voids within the AO. As expected, the AW is warmest where it enters the AO at Fram Strait with a mean potential temperature of $2.67^{\circ} \mathrm{C}$ in the NFMAB subbasin. Following the known AW pathway along the continental shelf north of Svalbard, Franz Josef Land, and the St. Anna Trough, the mean AW Layer potential temperature decreases slightly but generally remains warmer than $2^{\circ} \mathrm{C}$. In the Laptev Sea, the AW temperature falls to approximately $1.5^{\circ} \mathrm{C}$. This cooling is likely due to mixing resulting from atmospheric forcing as well as exchanges with the cooler, fresher shelf water. The AW remains around $1.5^{\circ} \mathrm{C}$ along the Amundsen Basin side of the Lomonosov Ridge up to the pole with some of this heat appearing to spread across the ridge into the Makarov Basin. The coldest mean AW is found in the Canada Basin where 
temperatures fall below $0.5^{\circ} \mathrm{C}$. The coldest $\mathrm{AW}$ mean potential temperature, $0.16^{\circ} \mathrm{C}$, is located in the NCCB subbasin close to the continental shelf.

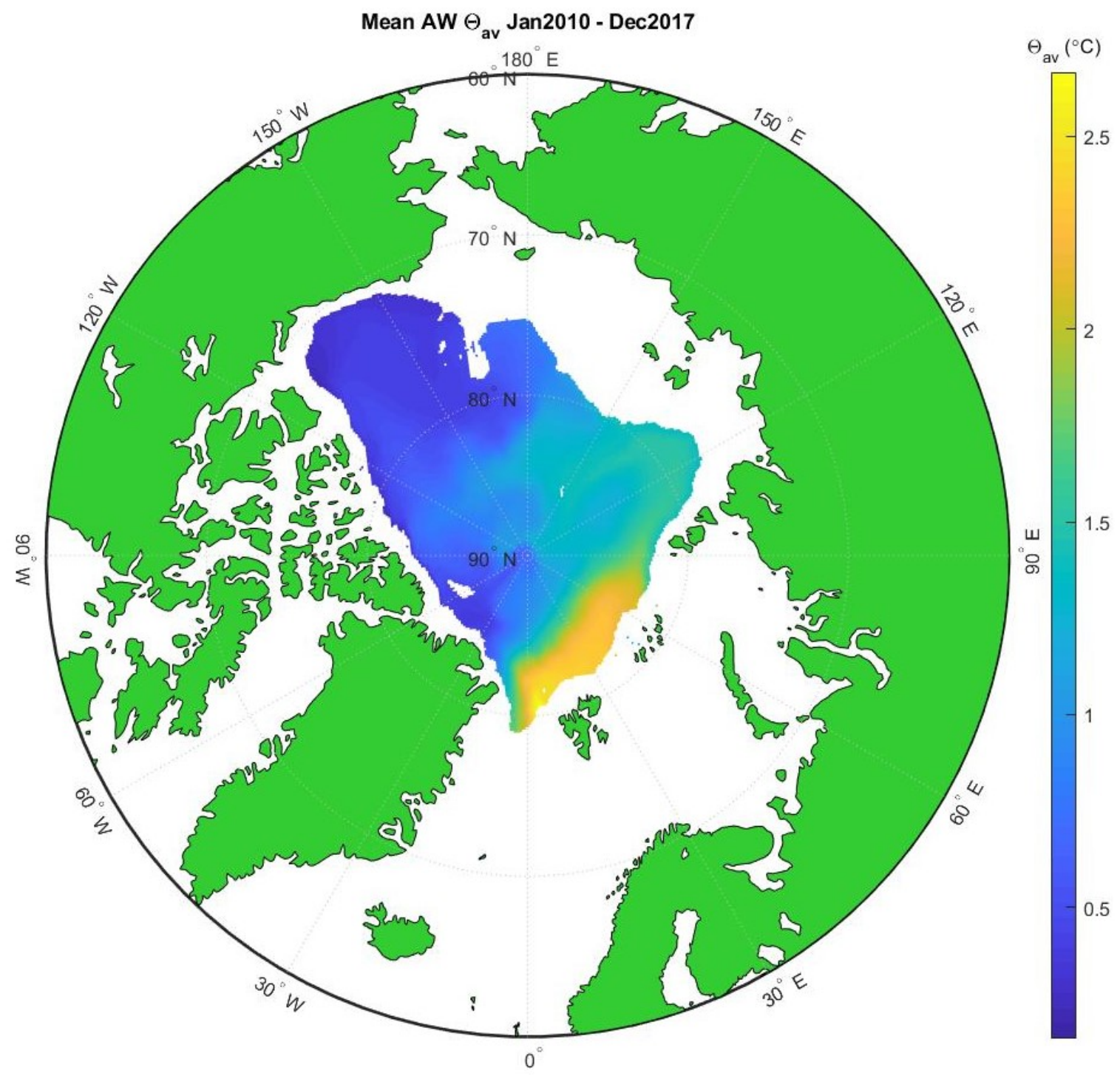

Figure 3-1: Mean AW Layer $\left(1028.2 \mathrm{~kg} / \mathrm{m}^{3}-1028.9 \mathrm{~kg} / \mathrm{m}^{3}\right)$ potential temperature, $\Theta_{a v}$, from January 2010 through December 2017 in ASTE. Values are displayed only for those grid cells where both upper and lower bounding isopycnals existed in each monthly mean profile.

The mean thickness of the AW Layer from January 2010 through December 2017 in ASTE is shown in Figure 3-2. The maximum mean AW thickness, $738 \mathrm{~m}$, is located in the ECNB subbasin along the continental shelf poleward of Severnaya Zemlya. The minimum mean AW thickness, $194 \mathrm{~m}$, occurs at an isolated location near Franz Josef Land in the NCNB. In the AO proper, the AW Layer is thickest following the published AW pathway along the continental shelf in the Nansen Basin continuing into the Laptev Sea, and along 
the Lomonosov Ridge toward the pole. The AW is thinner away from the ridge and shelf. The mean AW Layer thickness is less on the North American side of each basin. Lateral variations in AW thickness are related to the geostrophic circulation through the thermal wind balance.

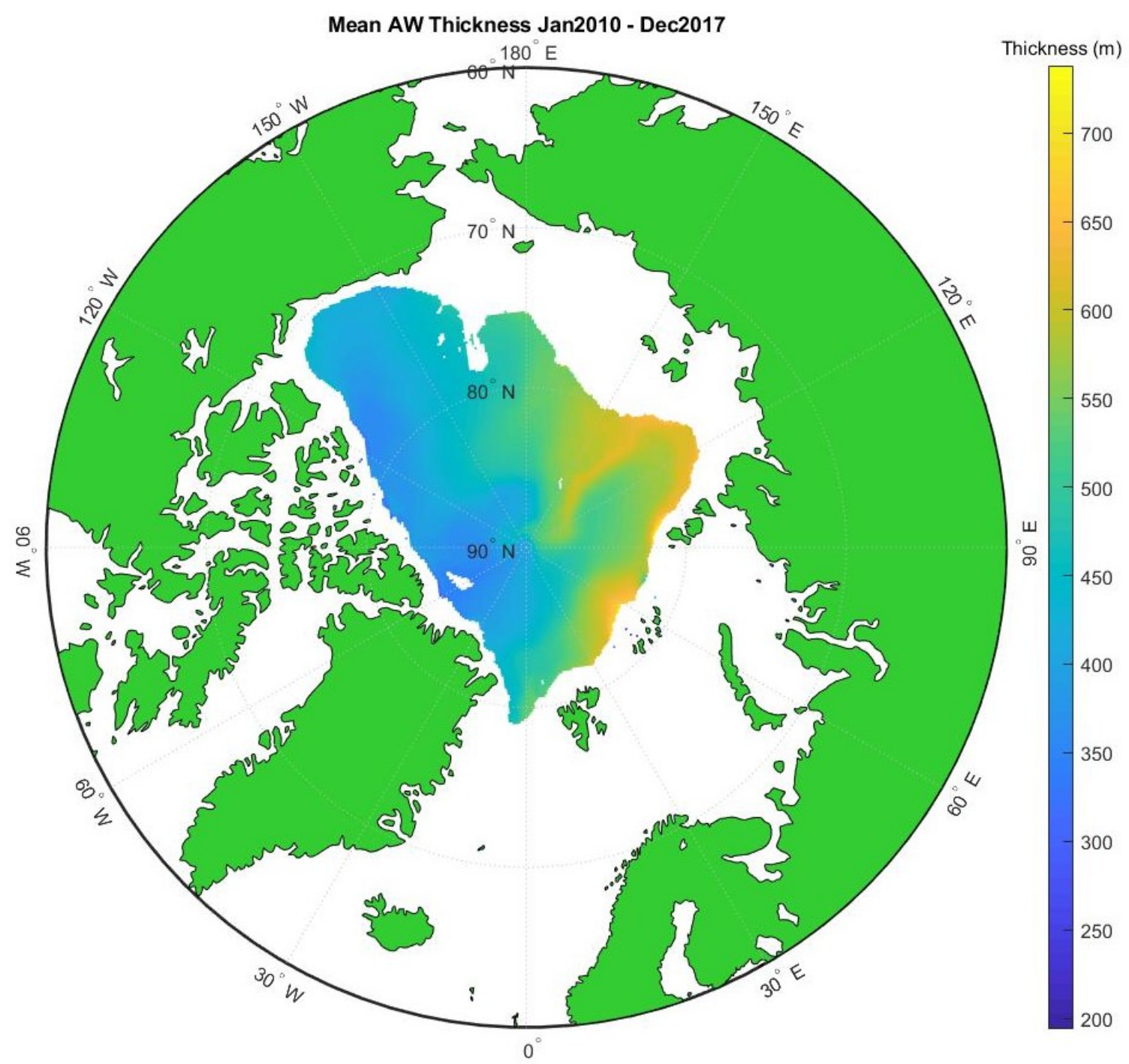

Figure 3-2: Mean AW Layer $\left(1028.2 \mathrm{~kg} / \mathrm{m}^{3}-1028.9 \mathrm{~kg} / \mathrm{m}^{3}\right)$ thickness from January 2010 through December 2017 in ASTE. Values are displayed only for those grid cells where both upper and lower bounding isopycnals existed in each monthly mean profile.

The spatial variability of the depths for the mean AW bounding isopycnals provide additional insight into causes of mean AW Layer thickness variability in the AO. Figure 3-3 displays the mean depth of the $1028.2 \mathrm{~kg} / \mathrm{m}^{3}$ bounding AW isopycnal in ASTE from January 2010 through December 2017. The minimum mean AW upper isopycnal depth is $35 \mathrm{~m}$ which occurs near Fram Strait in the NFMAB subbasin. The upper isopycnal 
outcrops to the surface in many locations near Fram Strait. This location has the minimum mean depth which does not have the upper isopycnal outcropping in any monthly mean file over the averaging time period. The upper isopycnal is shoalest relative to the rest of the AO near the AW inflow areas between Fram Strait and the Barents Sea. Buoyancy input by Bering Strait inflow, P-E and ice melting in combination with mixing cause the 1028.2 $\mathrm{kg} / \mathrm{m}^{3}$ isopycnal to deepen with distance from Fram Strait. The deepest mean $1028.2 \mathrm{~kg} / \mathrm{m}^{3}$ isopycnal is located in the ECCB subbasin north of Alaska where AW is furthest from its source and more buoyant water from the Pacific overlies the AW. While spatial variations in mean AW Layer thickness mirror geographic features such as the Lomonosov Ridge, the spatial distribution of mean upper isopycnal depth does not. The upper AW isopycnal depths generally increase uniformly based on distance from its entrance into the AO. A large gradient exists within Fram Strait where the AW inflow near Svalbard lies alongside outgoing AW in the East Greenland Current. 


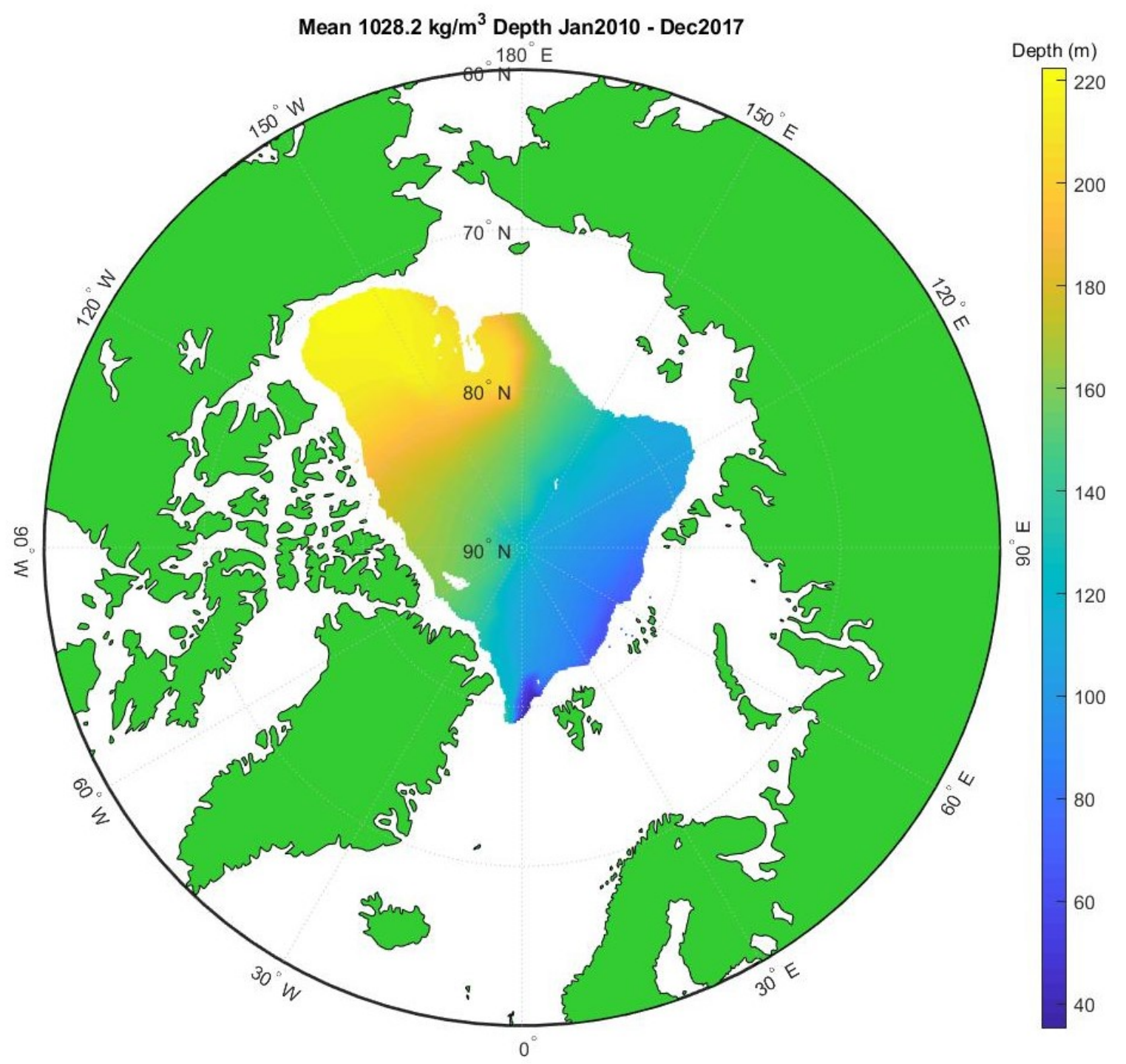

Figure 3-3: Mean $1028.2 \mathrm{~kg} / \mathrm{m}^{3}$ isopycnal depth from January 2010 through December 2017 in ASTE. Only grid cells where both top and bottom AW bounding isopycnals exist in every monthly mean file are displayed.

The mean depth of the lower AW isopycnal, $1028.9 \mathrm{~kg} / \mathrm{m}^{3}$, in ASTE from January 2010 through December 2017 is displayed in Figure 3-4. The deepest mean depth for the 1028.9 $\mathrm{kg} / \mathrm{m}^{3}$ isopycnal is $825 \mathrm{~m}$ and occurs at the same location as the maximum mean AW thickness just north of Severnaya Zemlya. The minimum mean lower isopycnal depth occurs in an isolated location near Franz Josef Land at $256 \mathrm{~m}$ depth which is where minimum AW thickness occurred. The mean lower isopycnal depth for this time period shows that the deepest locations occur near inflow areas and along the Eurasian side of the AO. The Lomonosov Ridge is seen as an area of greater mean lower isopycnal depths relative to 
locations away from the shelves and ridge. Thus, much of the spatial variability in AW thickness which manifested geographic features is due to the spatial variability of the lower isopycnal. Similar to mean AW thickness, the shallower mean lower AW isopycnal depths are seen on the North American sides of the AO compared to the Eurasian side.

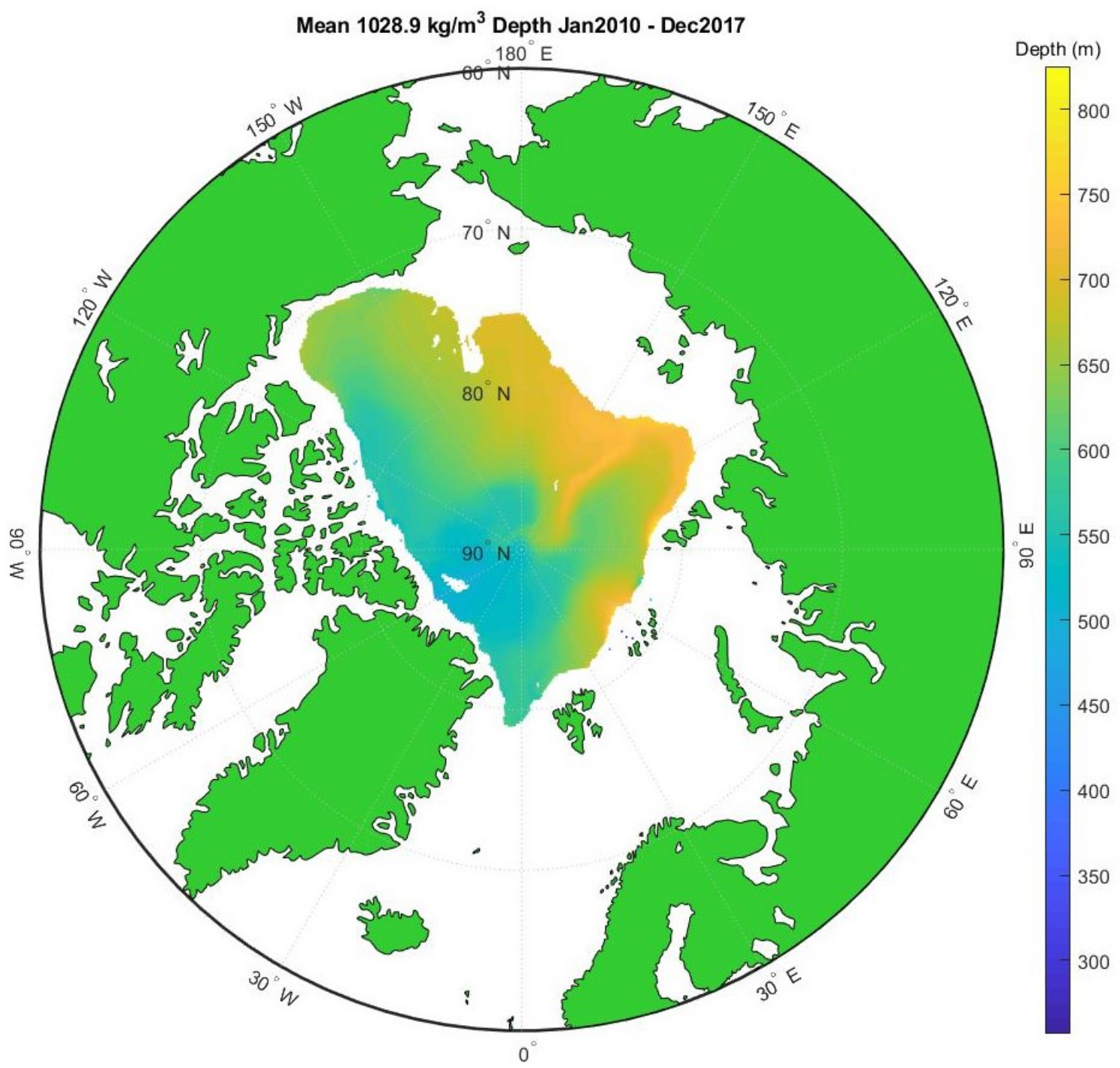

Figure 3-4: Mean $1028.9 \mathrm{~kg} / \mathrm{m}^{3}$ isopycnal depth from January 2010 through December 2017 in ASTE. Values are displayed only for those grid cells where both upper and lower bounding isopycnals existed in each monthly mean profile.

\subsection{Atlantic Water Time-Mean Circulation}

The full, time-mean transport streamfunction is contoured at a $0.25 \mathrm{~Sv}$ interval in Figure 3-5 to identify AW circulation pathways in ASTE. As discussed in Section 2.6, this version of 
streamfunction is calculated by integrating the $\mathrm{x}$-directed transport in the y-direction. This calculation works best for the Fram Strait, Barents Sea, and Bering Strait flows but not for the flow through the Canadian Archipelago which is oriented better for integrating the $y$ directed transport in the x-direction. Since the AW volume transport through the Canadian Archipelago is an order of magnitude smaller than the other locations (Fram Strait and the Barents Sea), the presented x-directed version of streamfunction is used to describe general AW patterns in the AO, and the AW flow through the Canadian Archipelago, specifically the Nares Strait, will be quantified separately in the discussion of the overturning circulation.

The full streamfunction is composed of both the divergent and non-divergent flow. Beginning at Fram Strait, 3.6 Sv of AW enters the AO on average. Some of the AW then immediately recirculates back through Fram Strait as seen in the streamlines curving back toward Greenland. Approximately $1.8 \mathrm{~Sv}$ of AW turns to the right along the continental shelf north of Svalbard, indicating that approximately $1.8 \mathrm{~Sv}$ recirculates within Fram Strait.

The Barents Sea Branch contributes approximately 1.5 Sv of AW to the AO. This contribution was based on multiple model locations: off the coast of Novaya Zemlya and in the St. Anna Trough. After both inflow branches merge at Severnaya Zemlya, the mean boundary current transport is $2.7 \mathrm{~Sv}$. The AW flows cyclonically into the Laptev Sea with the majority of the flow, $2.4 \mathrm{~Sv}$, turning along the Lomonosov Ridge and only $0.5 \mathrm{~Sv}$ crossing the ridge adjacent to the shelf and continuing as a circumpolar current.

After turning at the Lomonosov Ridge, 1.2 Sv of AW crosses the Lomonosov Ridge rather than following the ridge and passing through Fram Strait as depicted in Figure 1-1 from Rudels et al., 2012 [2] and Mauritzen et al., 2013 [1]. The time-mean flow also indicates there is a cyclonic gyre on the Eurasian side of the ridge near the Laptev Sea with a couple closed streamfunction contours.

The AW flow that crossed the Lomonosov Ridge enters the Makarov Basin and the Canada Basin before turning toward Fram Strait at the North American shelf north of the Canadian Archipelago. The divergent component of the flow results in transport streamlines appearing to intersect the North American coast. In the Canada Basin, AW flows anticyclonically which is the direction the upper ocean in the Beaufort Gyre circulates. This flow is not depicted in Figure 1-1.

The AW which crossed the Lomonosov Ridge returns toward Fram Strait along the North American continental shelf with $0.9 \mathrm{~Sv}$ recrossing the ridge near the shelf break. Finally, 
2.2 $\mathrm{Sv}$ of now cooler and fresher AW exits the $\mathrm{AO}$ on the Greenland side of Fram Strait in the East Greenland Current. Apart from the Barents Sea, the Nares Strait in the Canadian Archipelago and Fram Strait, the AO is closed to AW flow since the Bering Strait and most of the Canadian Archipelago passages are too shallow to permit AW exchange. AW outflow occurs mostly through Fram Strait and to a lesser extent through Nares Strait since the Barents Sea contributes only to AW inflow.

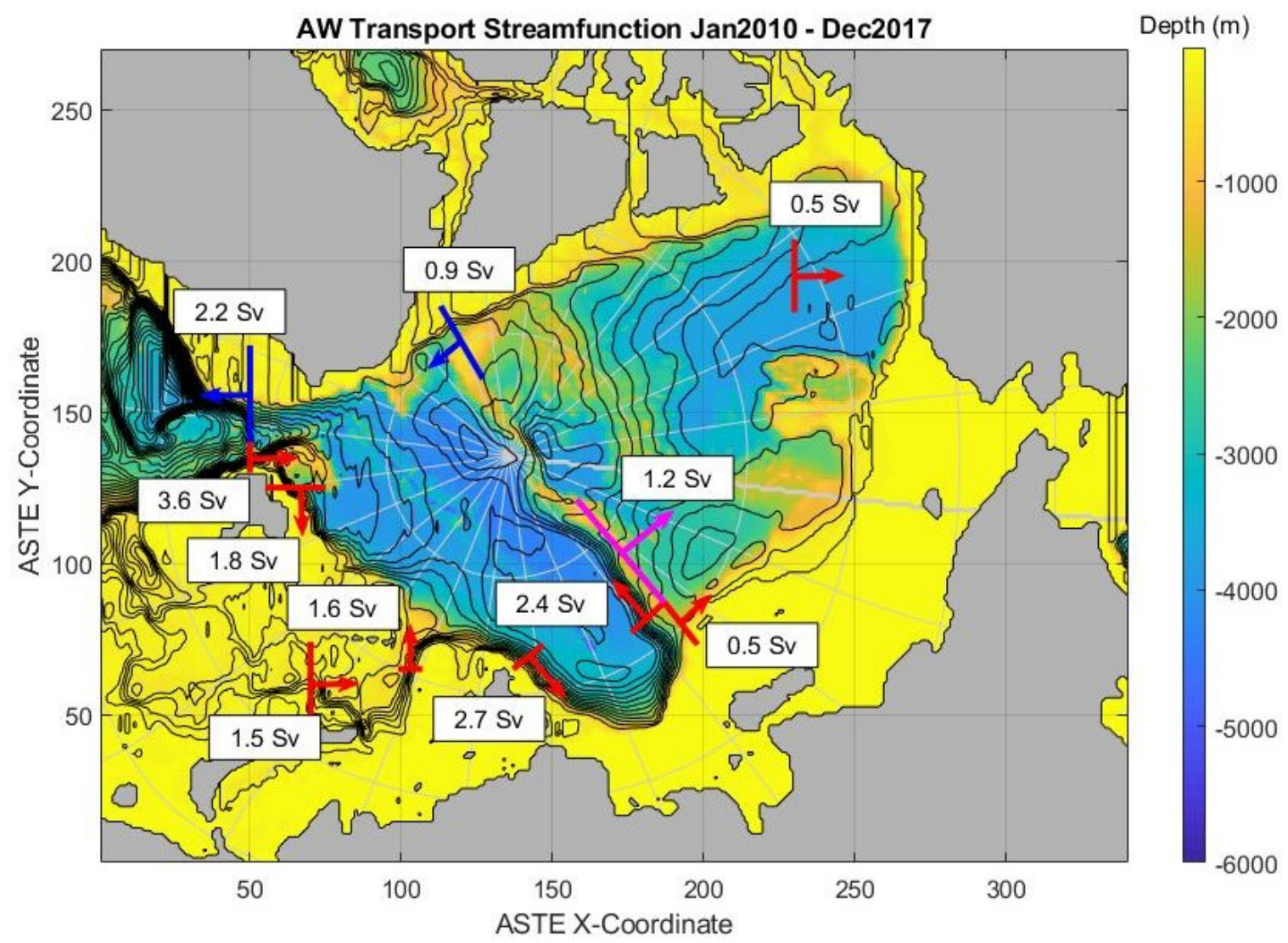

Figure 3-5: The full (divergent and non-divergent) transport streamfunction for the mean AW Layer $\left(1028.2 \mathrm{~kg} / \mathrm{m}^{3}-1028.9 \mathrm{~kg} / \mathrm{m}^{3}\right)$ from January 2010 through December 2017 in ASTE output. The contour interval is $0.25 \mathrm{~Sv}$. Bathymetry is indicated with color.

A non-unique depiction of the non-divergent, time-mean circulation of the AW Layer in ASTE is shown in Figure 3-6. Similar to the full transport field, the non-divergent transport streamfunction is contoured at a $0.25 \mathrm{~Sv}$ interval and overlayed on ASTE bathymetry. Generally, the non-divergent AW flow parallels the full streamfunction. The same locations used to compute the volume transport in Figure 3-5 are used in the non-divergent case as well. Most values are a few tenths of a Sverdrup less than the full streamfunction case as could be expected since the full transport is the sum of the non-divergent and divergent 
fields.

The non-divergent streamlines more clearly show the AW from Fram Strait following isobaths in the St. Anna Trough. The cyclonic circulation on the Eurasian side of the Amundsen Basin is better defined with additional closed streamlines. The same AW partitioning occurs at the Lomonosov Ridge with the majority of AW following the ridge rather than continuing as the Circumpolar Boundary Current. Along the ridge, AW spills over into the Makarov Basin rather than return directly to Fram Strait, although the cross-ridge transport is $0.3 \mathrm{~Sv}$ less than the full flow. The anticyclonic circulation in the Beaufort Gyre remains. Since the non-divergent streamfunction is forced to zero at the North American coast, the return flow toward Fram Strait is stronger along the Canadian Archipelago with 1.3 Sv recrossing the Lomonosov Ridge. The outflow in Fram Strait also increases to 3.0 Sv.

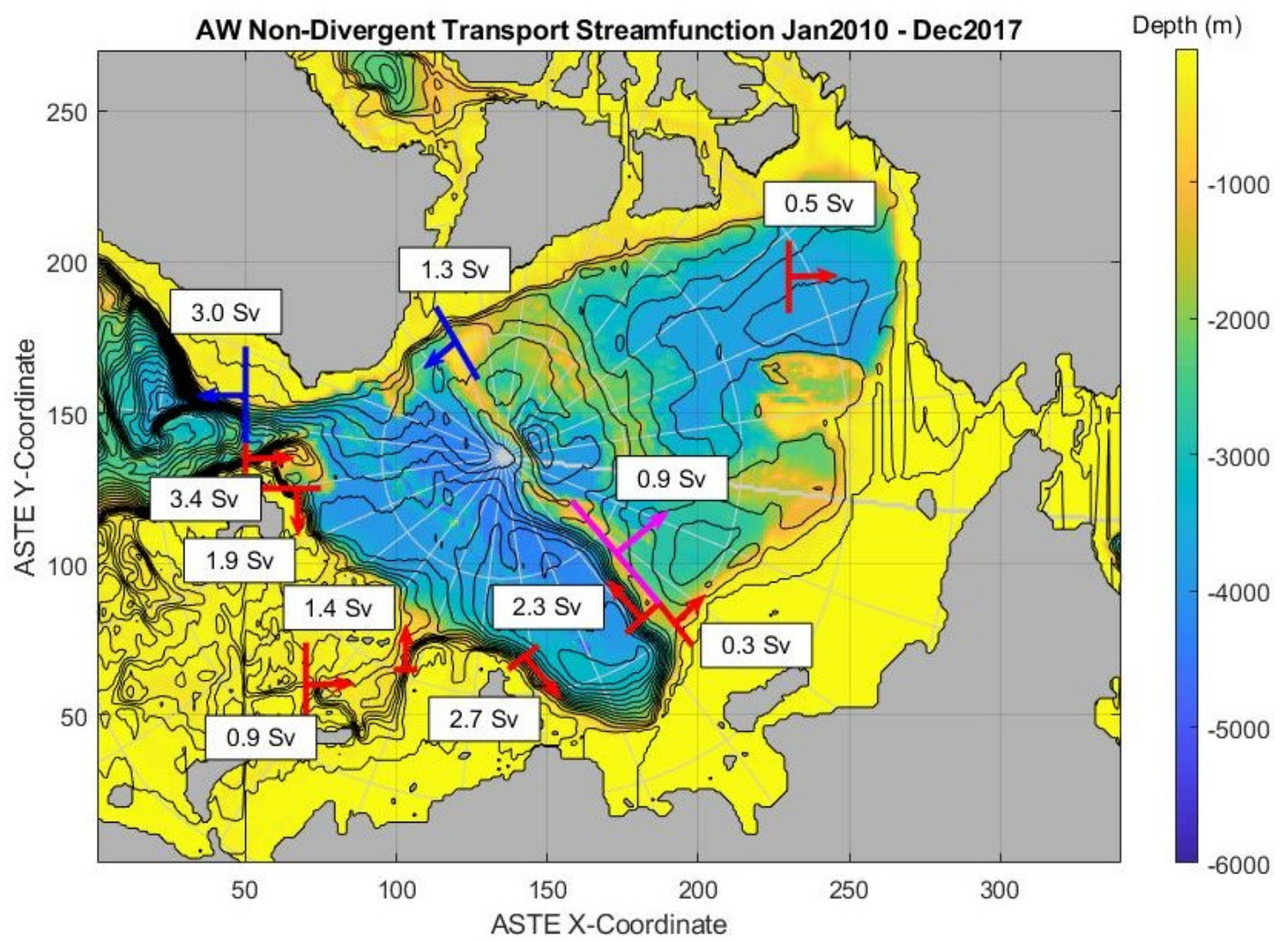

Figure 3-6: The non-divergent Transport Streamfunction for the mean AW Layer (1028.2 $\left.\mathrm{kg} / \mathrm{m}^{3}\right)-1028.9 \mathrm{~kg} / \mathrm{m}^{3}$ ) from January 2010 through December 2017 of monthly mean ASTE output. The contour interval is $0.25 \mathrm{~Sv}$.

To better visualize the AW flow field, streamlines of the depth-averaged mean AW Layer velocity for grid cells that contained both AW bounding isopycnals from January 2010 
through December 2017 are shown in Figure 3-7 overlayed on bathymetry. Streamlines show the circulations in the AW described by the streamfunction with a few additional features. On the Eurasian side of the Makarov Basin, an anticyclonic circulation exists in the time-mean flow just east of the Lomonosov Ridge. This circulation is not depicted in published flow paths, such as in Figure 1-1, which suggest an uninterrupted AW circumpolar boundary current along the continental shelf.

The AW also circulates cyclonically on the North American side of the Makarov Basin west of the Lomonosov Ridge. This circulation includes some of the AW which crossed the Lomonosov Ridge after turning poleward as well as the returning AW along the continental shelf. The anticyclonic circulation in the Beaufort Gyre is clear.

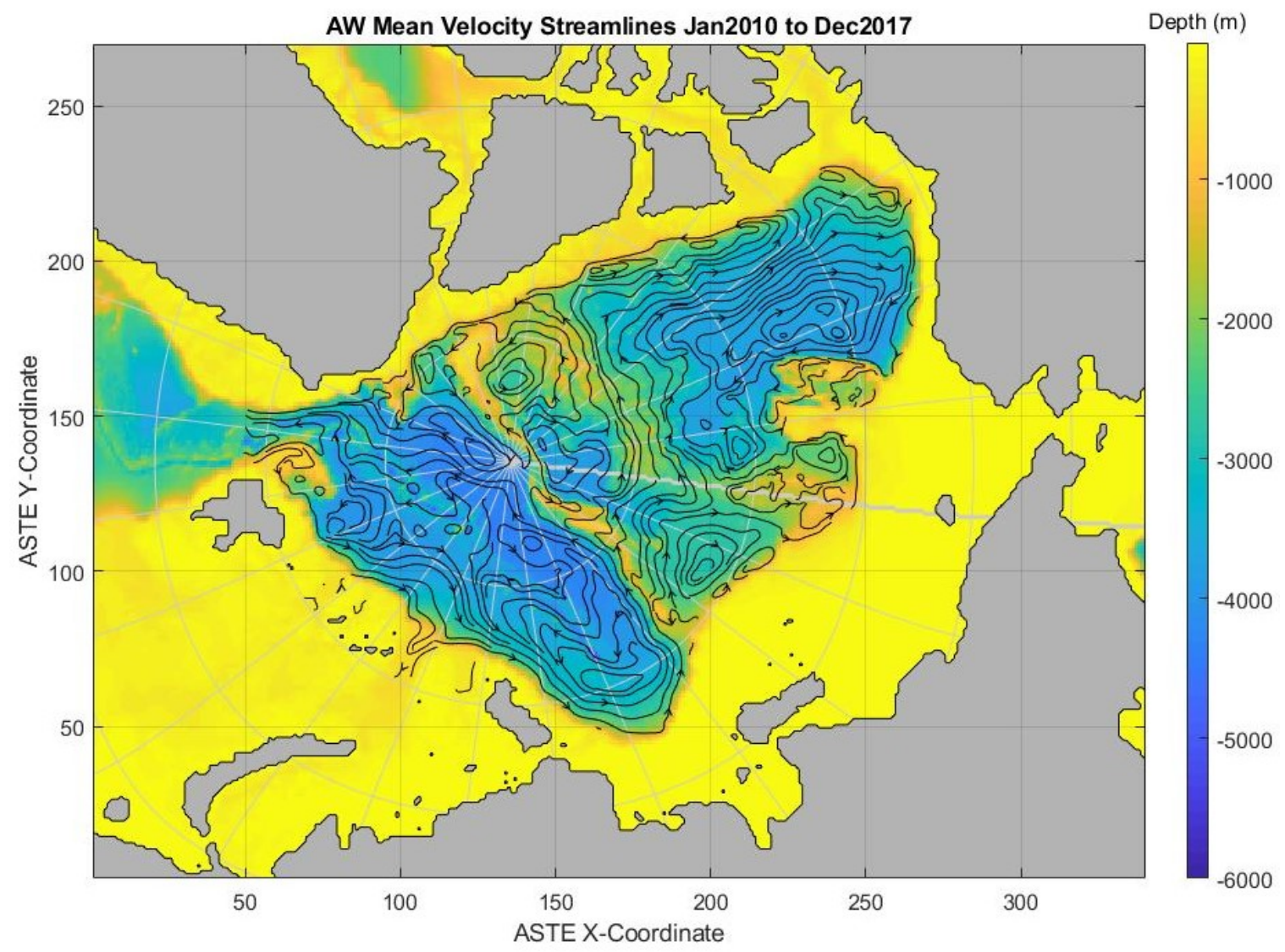

Figure 3-7: Streamlines for the mean AW Layer velocity from January 2010 through December 2017.

Water mass transformation within the $\mathrm{AO}$ has been discussed as an important driver for AW flow into the AO [11]. To view the overturning circulation within ASTE, the AO is divided into three layers: a Surface Layer, the AW Layer, and a Bottom Layer. The volume of each layer within the AO in ASTE, starting at ASTE X-Coordinate 50 (Fram Strait and 
the Barents Sea) and ending at ASTE X-Coordinate 310 (the Bering Strait), is calculated for every month. The change in volume for each layer across the entire AO from January 2010 through December 2017 is calculated by subtracting the former volume from the latter volume and dividing by time. This provides the estimated change in volume of each layer in ASTE over this time period.

Next, the mean net volume transport by the ocean into and out of each layer is calculated at the $\mathrm{AO}$ boundaries. The net of the u-directed ocean volume transport in each layer calculated from the full streamfunction, as discussed in Section 2.6, at ASTE X-Coordinate 50 represents the net volume flux for Fram Strait and the Barents Sea. Similarly, the net of the $\mathrm{u}$-directed ocean volume transport at ASTE X-Coordinate 310 is taken as the volume flux through Bering Strait. The volume transport through the Canadian Archipelago is calculated using the v-directed ocean volume transport at the four archipelago passages in the model. The water mass transformations between the layers are then estimated through volume conservation. Contributions to the Surface Layer such as river runoff and E-P are neglected as they are on the order of a tenth of a Sverdrup or less [35].

The resulting ASTE mean overturning circulation is displayed in Figure 3-8. The Surface Layer showed a slight imbalance in volume of a tenth of Sverdrup. There is a net inflow of Surface Water at Bering Strait of 1.0 Sv which is consistent with transport observations [36], a net outflow in the Canadian Archipelago of $1.3 \mathrm{~Sv}$ (chiefly through Nares Strait), and a net outflow at Fram Strait/Barents Sea of $0.8 \mathrm{~Sv}$. The sum of these three transports results in a net surface ocean export of AO Surface Water of $1.3 \mathrm{~Sv}$. Thus, through continuity, approximately $1.2 \mathrm{~Sv}$ of AW must be transformed into Surface Water within the AO.

Below the AW Layer, the Bottom Layer has an overall rate of volume decrease with time of $1.5 \mathrm{~Sv}$ from January 2010 to December 2017 and a net outflow of $1.9 \mathrm{~Sv}$ through Fram Strait. Bottom Water is blocked from entering or exiting through the Bering Strait and Canadian Archipelago due to much shallower water depths in these passages. Thus, $0.4 \mathrm{~Sv}$ of AW must be transformed into Bottom Water to conserve volume.

From January 2010 to December 2017, the AW Layer in ASTE increased in volume by an average rate of $1.4 \mathrm{~Sv}$. There was a net inflow into the Barents Sea and Fram Strait of 3.1 Sv and a net outflow of 0.3 Sv through the Canadian Archipelago in the Nares Strait. The continental shelf prevents AW from passing through the Bering Strait. The computed transports result in an imbalance of $0.2 \mathrm{~Sv}$ within the AW Layer which could be the result 
of imperfect vertical integration of a level model, no accounting for flow within grid cells, bottom triangles, and neglect of the eddy bolus flux when computing transports with the monthly mean ASTE output.

\section{Arctic Ocean Mean Overturning Circulation}

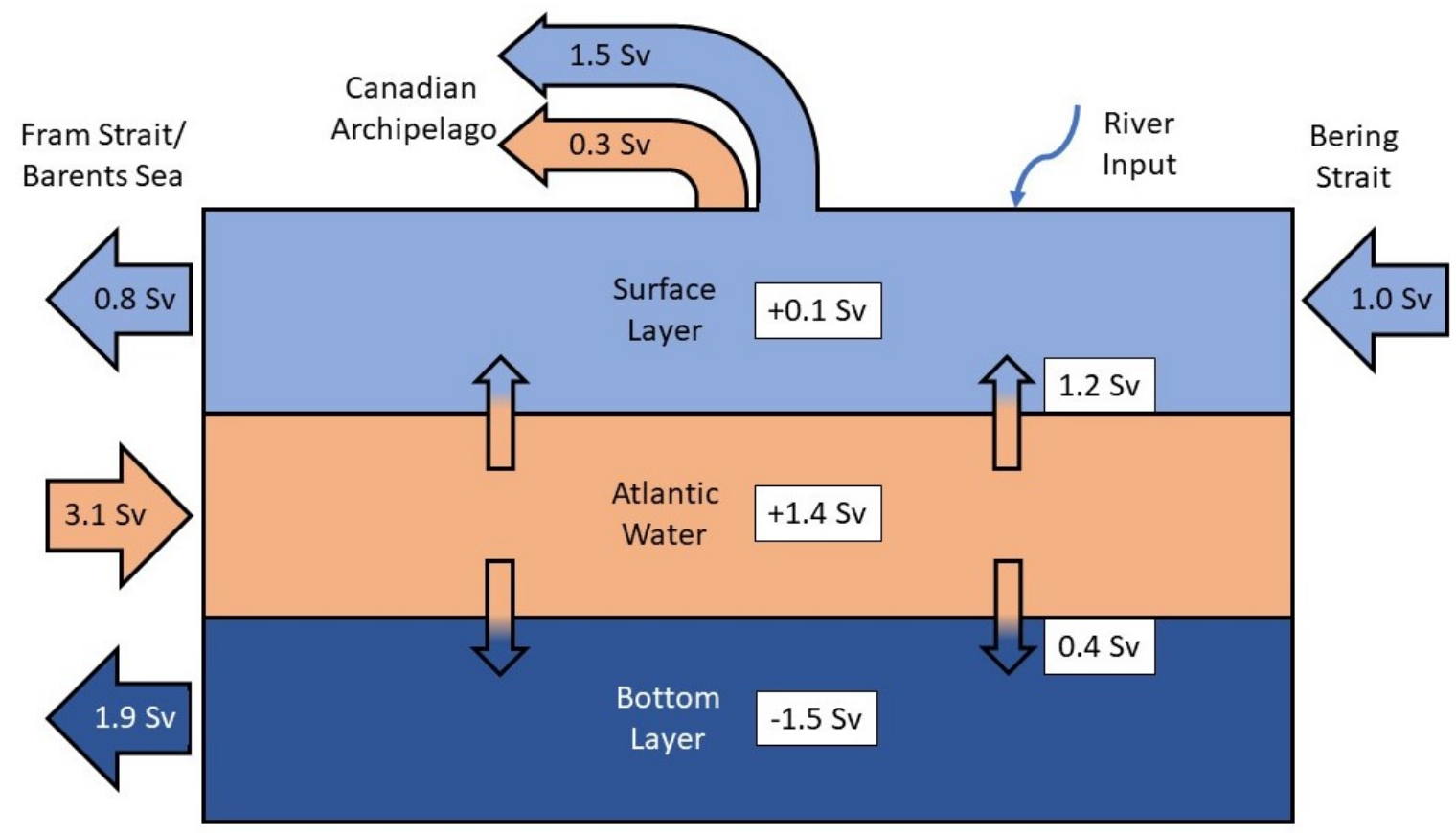

Figure 3-8: The mean overturning circulation for the Surface Layer, AW Layer, and Bottom Layer from January 2010 through December 2017 in ASTE.

\subsection{Atlantic Water Time-Varying Circulation}

In this section, the time-varying AW circulation is investigated. First, seasonal variability of the AW circulation is discussed followed by an analysis of the interannual variability.

\subsubsection{Seasonal Variability}

The mean annual cycle of AW flow into and out of the AO was constructed by averaging the volume transport estimates for each month of the year between 2010 and 2017, Figure 3-9. The Fram Strait AW inflow and outflow as well as the Barents Sea AW inflow are calculated from the full transport streamfunction using the same locations depicted in Figures $3-5$ and 3-6 with the Barents Sea inflow calculated based on the transport off the coast of Novaya Zemlya. The volume transport of AW into and out of the Arctic is greatest during winter 
and least during summer. The AW inflow through Fram Strait is generally over twice as large as the Barents Sea inflow for all months, but as seen in the time-mean AW circulation, some of the AW entering Fram Strait recirculates and exits Fram Strait rather than entering the AO proper north of Svalbard. The seasonal variability of the average Fram Strait inflow (2.8 Sv difference between winter and summer) is greater than the variability of the outflow through Fram Strait $(1.1 \mathrm{~Sv})$ as well as that of the Barents Sea inflow (1.5 Sv).

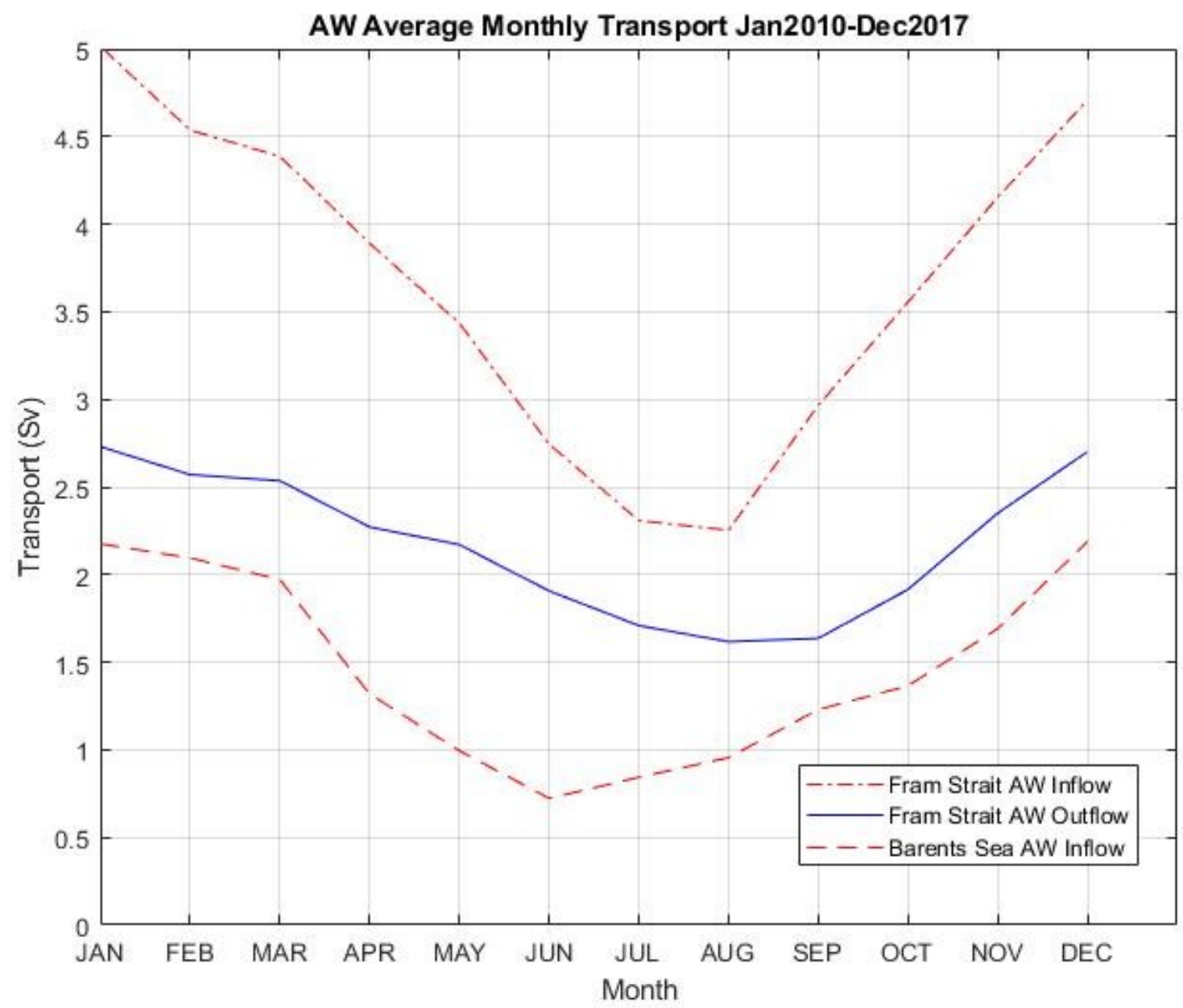

Figure 3-9: The average seasonal cycle of volume transport for the AW inflow through Fram Strait (red, dash-dot), AW outflow through Fram Strait (blue, solid), and AW inflow through the Barents Sea (red, dashed) for each month from January 2010 through December 2017. The locations used to calculate the volume transport are depicted in Figures 3-5 and 3-6. The location used for the Barents Sea inflow is off the coast of Novaya Zemlya.

The average speed of the AW along the Lomonosov Boundary Current contour, Figure 2-3, is then computed for each month of ASTE output. A time average from 2010 through 2017 is then calculated for each particular month to produce Figure 3-10. The AW Layer 
following this contour, which is used to describe the Lomonosov Boundary Current, is fastest in January with an average speed of slightly greater than $2.6 \mathrm{~cm} / \mathrm{s}$. The slowest AW Layer flow occurs in July with an average speed of approximately $1.9 \mathrm{~cm} / \mathrm{s}$. This describes a seasonal cycle of the AW boundary current that is fastest in winter and slowest in summer.

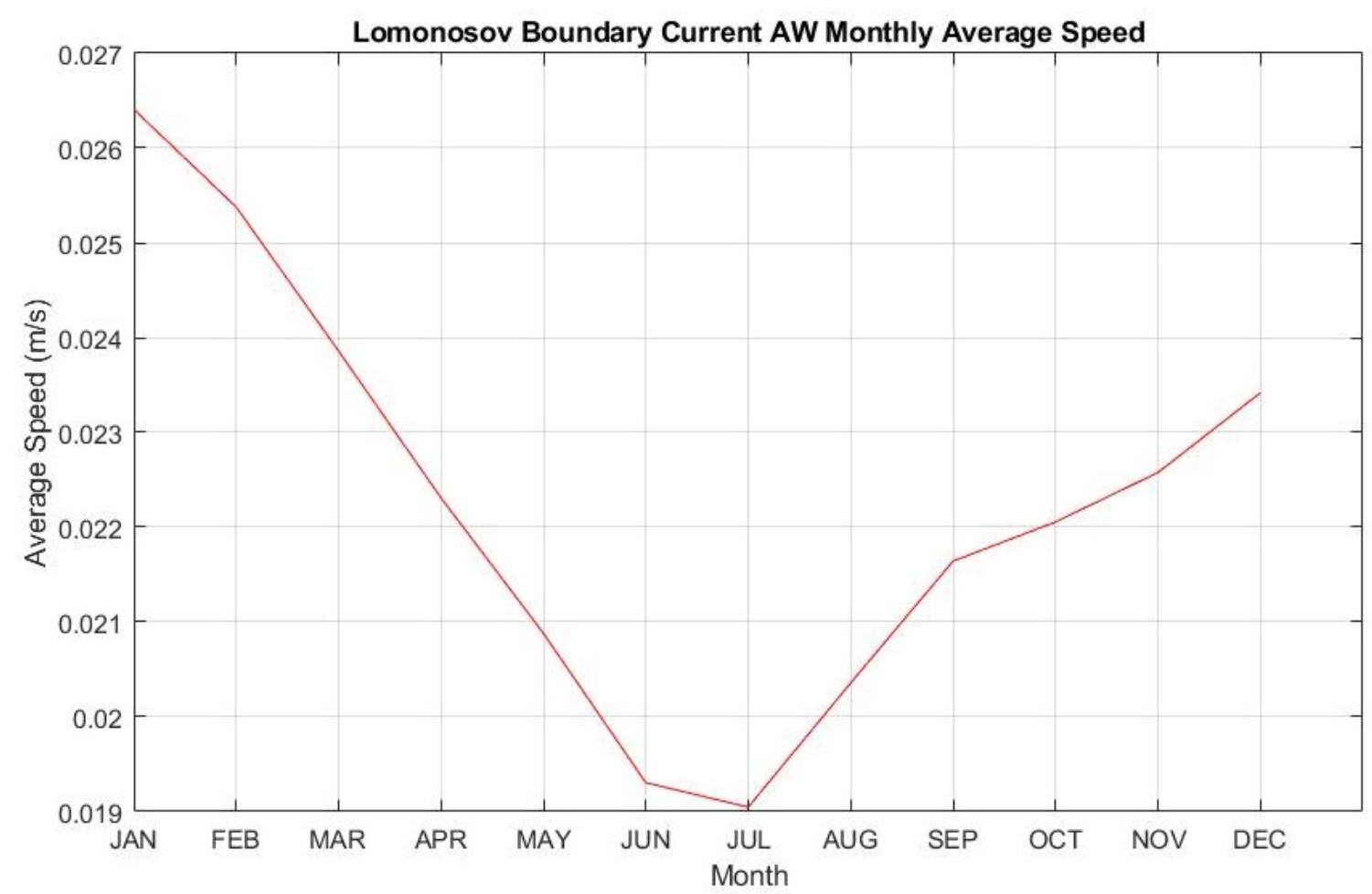

Figure 3-10: The average speed of the AW Layer for each month along the Lomonosov Boundary Current contour from 2010-2017.

The average speed of the AW along the Circumpolar Boundary Current contour, Figure $2-4$, is computed for each month from 2010 through 2017. The result is shown in Figure 3-11. The fastest average AW speeds are found in February with an average speed of approximately $2.4 \mathrm{~cm} / \mathrm{s}$. The slowest AW Layer speed occurs in June with an average speed of approximately $1.9 \mathrm{~cm} / \mathrm{s}$. Similar to the Lomonosov Boundary Current, the seasonal cycle of the AW Layer in the Circumpolar Boundary Current shows faster AW flow in winter and slower speeds in summer. Compared to the Lomonosov Boundary Current, the transition from winter speeds to the slower summer speeds occurs over a shorter amount of time with a longer summer relaxed state extending into late summer/early fall. 


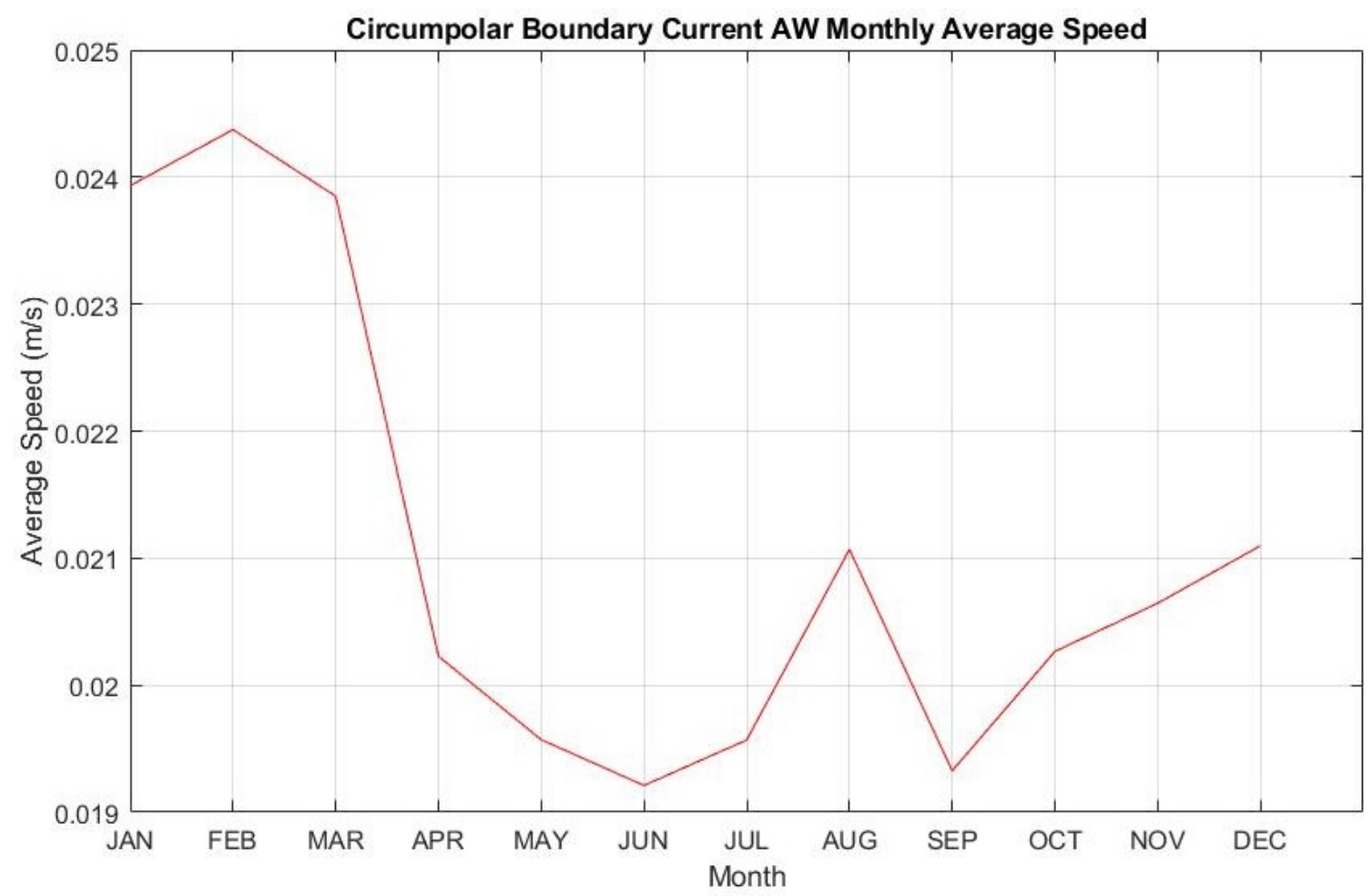

Figure 3-11: The average AW Layer speed for each month along the Circumpolar Boundary Current contour from 2010-2017.

\subsubsection{Interannual Variability}

The time series of AW transport through Fram Strait and into the AO from the Barents Sea is shown in Figure 3-12. The seasonal cycle just discussed is discernible in the annual undulation with maximums in winter and minimums in summer. An overall increase in volume transport occurs in 2004 to 2005 for all three locations. This is best seen in the wintertime maximum values. The Fram Strait AW inflow winter maximum in 2002 is less than $3 \mathrm{~Sv}$ but increases to $5 \mathrm{~Sv}$ in 2004. The winter maximum reaches its highest value of approximately $8 \mathrm{~Sv}$ in January 2005; in all later years the maximum stays between $5 \mathrm{~Sv}$ and $7 \mathrm{~Sv}$ which is greater than the maximums before January 2004.

The AW exiting the AO through Fram Strait also increases its throughput after January 2003 with a maximum in January 2005 of 3.6 Sv. Starting in 2005, winter maximums are approximately $3 \mathrm{~Sv}$ which is greater than the maximums prior to January 2005 which are less than $2 \mathrm{~Sv}$.

The increase in Barents Sea AW inflow occurs between 2004 and 2006. Unlike the Fram Strait transports, the maximum volume transport, 4.2 Sv, occurs in February 2012 rather 
than 2005. Also, the seasonal minimum values for the Barents Sea inflow do not show an overall increase after 2004 and instead remain less than 1 Sv during the entire ASTE output period.

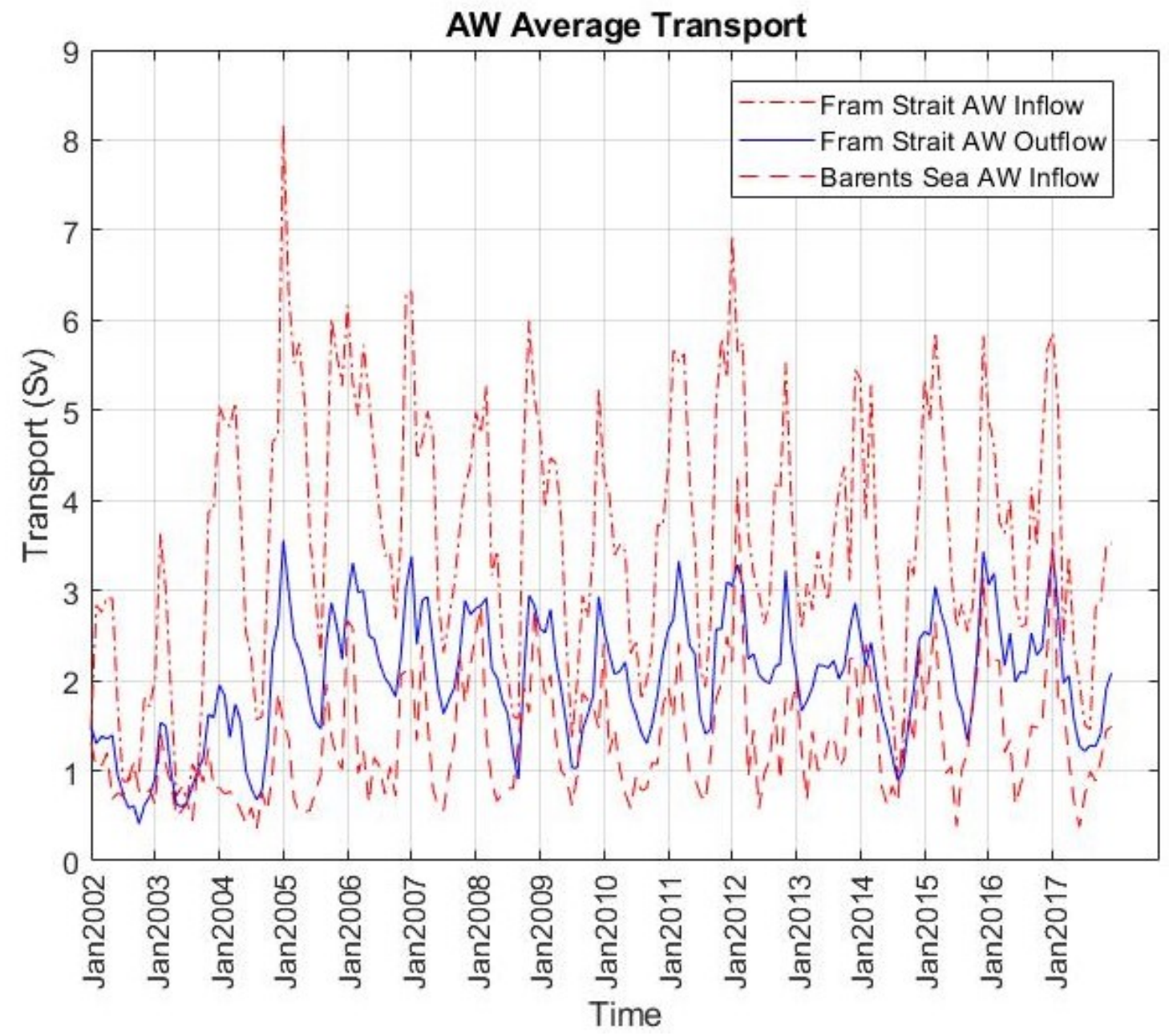

Figure 3-12: The average volume transport for the AW inflow through Fram Strait (red, dash-dot), AW outflow through Fram Strait (blue, solid), and AW inflow through the Barents Sea (red, dashed) for each month of ASTE output. The locations used to calculate the volume transport are depicted in Figures 3-5 and 3-6 with the Barents Sea inflow based on the coordinates off the coast of Novaya Zemlya.

The average speed of AW along the Lomonosov Boundary Current contour for each month of ASTE output is plotted in Figure 3-13. For the first two years of ASTE output, the Lomonosov Boundary Current average speed is around $1.2 \mathrm{~cm} / \mathrm{s}$. An increase in the average speed is seen late in 2003. The 36 month running mean of AW speed along the contour reaches a steady state in 2006 with a mean value of approximately $2.1 \mathrm{~cm} / \mathrm{s}$. The increased current speeds in winter and reduced periods during summer are visible in the 
fluctuations about the mean. Maximum AW average speeds are around $3.0 \mathrm{~cm} / \mathrm{s}$ while the the minimum values are around $1.5 \mathrm{~cm} / \mathrm{s}$.

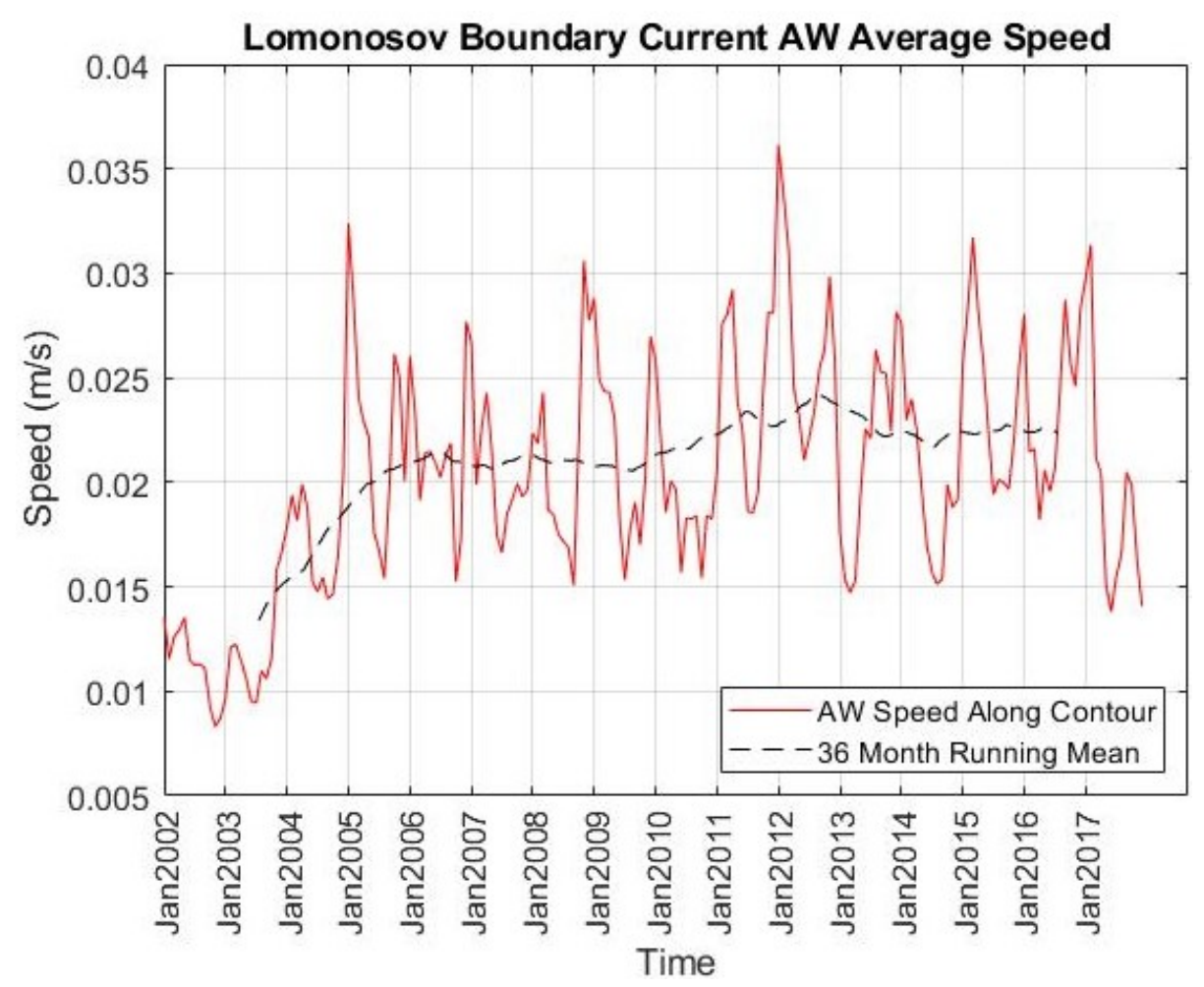

Figure 3-13: The average AW speed along the Lomonosov Boundary Current contour for each month of ASTE output.

Figure 3-14 shows the interannual variation of AW average speed for the Circumpolar Boundary Current contour. As was seen for the Lomonosov Boundary Current contour, the AW along the Circumpolar Boundary Current contour is slower in 2002 and 2003 than the rest of the state estimate period. The current speed is on average approximately $1.2 \mathrm{~cm} / \mathrm{s}$ in 2002. In 2004, the Circumpolar Boundary Current speed increases as indicated by the 36 month running mean. Unlike the Lomonosov Boundary Current, the Circumpolar Boundary Current attains larger average speeds in 2006 reaching a maximum in the 36 month average of $2.5 \mathrm{~cm} / \mathrm{s}$ before decreasing to $1.9 \mathrm{~cm} / \mathrm{s}$ in May 2010 . 


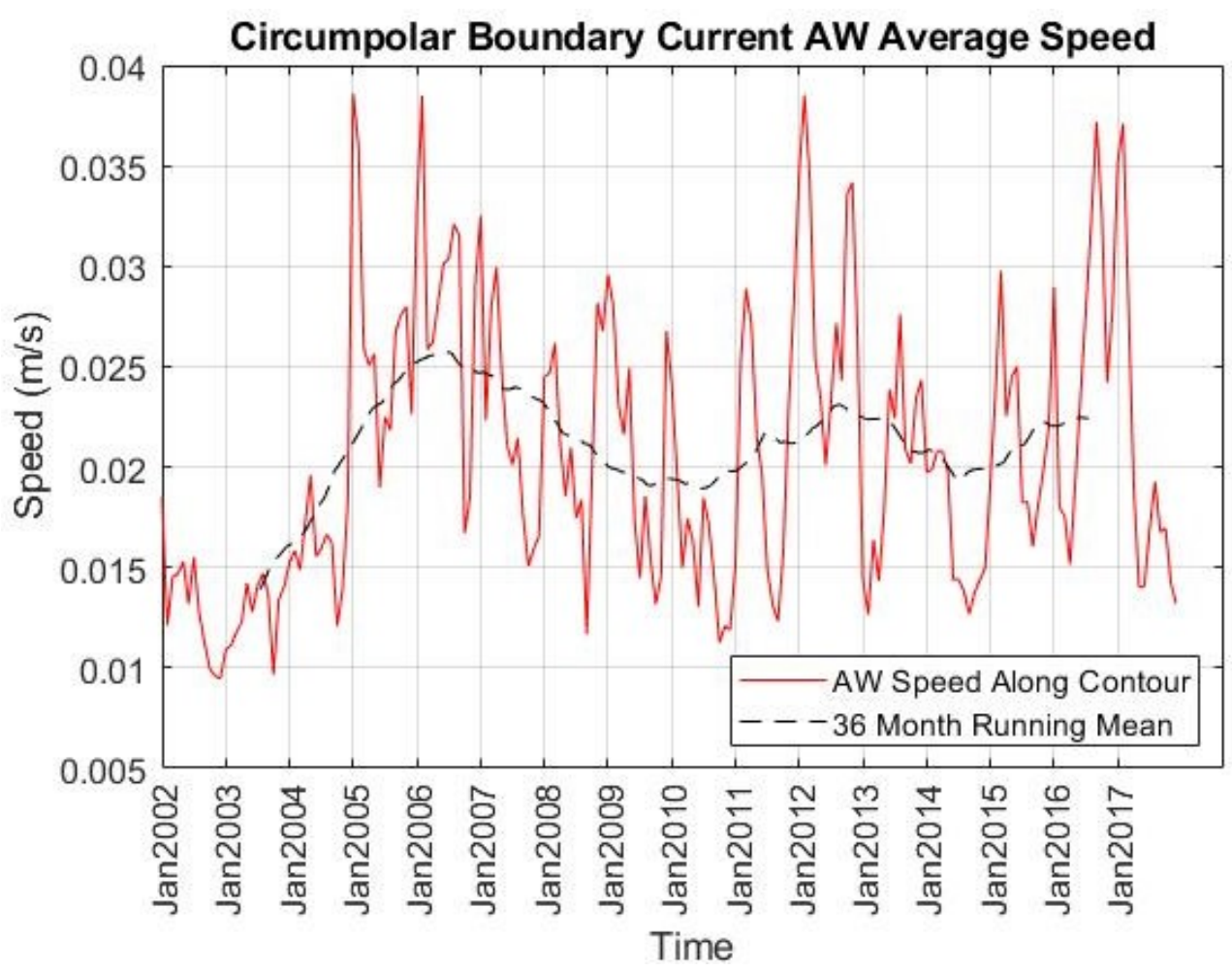

Figure 3-14: The average AW speed along the Circumpolar Boundary Current contour for each month of ASTE output.

Streamlines of mean AW Layer velocity in ASTE at four year intervals beginning with January 2002 are shown in Figure 3-15 to visualize and describe the evolution of AW Layer flow in the AO. In January 2002, the strongest AW currents are near the AW inflow areas and along the continental shelf of the Canadian Archipelago. Outside of these areas, the AW flow is generally $2 \mathrm{~cm} / \mathrm{s}$ or less. From the AW entrance regions (Fram Strait and the St. Anna Trough), the AW flows across the Nansen and Amundsen Basin toward the Lomonosov Ridge. On the Amundsen Basin side of the Lomonosov Ridge, the model AW flow is directed toward Eurasia. This is opposite the time-mean AW circulation described in Section 3.2 based on the 2010-2017 time-mean AW flow. The AW which crossed the Lomonosov Ridge at the Eurasian continental shelf flows into the mid Makarov Basin and along the Eurasian continental shelf. The Mendeleyev Ridge turns the AW toward the mid Makarov Basin with most of the AW eventually joining an anticyclonic circulation in the Beaufort Gyre. The AW forms a stronger current along the North American continental slope as a return flow toward Fram Strait.

The mean AW flow in January 2006 exhibits several differences compared to January 2002 and more closely resembles the time-mean circulation described earlier. Some of the 
AW entering Fram Strait turns to the east north of Svalbard and follows the continental shelf indicated by the $500 \mathrm{~m}$ contour in blue rather than continuing into the mid basin. The Fram Strait and Barents Sea AW meet in the St. Anna Trough to form a strong current with a speed of approximately $10 \mathrm{~cm} / \mathrm{s}$. AW follows a cyclonic path into the Laptev Sea with a bifurcation of AW flow at the Lomonosov Ridge. Some of the AW turns poleward at the Lomonosov Ridge, follows the ridge and crosses into the Makarov Basin. There is not a clear path of AW which parallels the Lomonosov Ridge and directly returns to Fram Strait. Instead, the AW spills over the ridge and flows toward the Canadian Archipelago in the Makarov Basin. A portion of AW also crosses the Mendeleyev Ridge into the Canada Basin. The AW that does not turn at the Lomonosov Ridge continues as the Arctic Circumpolar Boundary Current along the Eurasian continental shelf. The signature of the anticyclonic AW flow in the Beaufort Gyre is not clearly defined. All the mid subbasins contain recirculations adjacent to the main AW flow paths. The return flow of AW toward Fram Strait on the North American side of the AO remains relatively strong.

In January 2010, the AW flow field indicates a much stronger flow along the Lomonosov Ridge with fewer streamlines crossing the ridge. Also, there are streamlines showing that some AW follows along the ridge and returns to Fram Strait which is the generalized flow path described by Rudels et al. 2012 [2] and Mauritzen et al., 2013 [1] in Figure 1-1. The Arctic Circumpolar Boundary Current is weaker with no clear signature from the Mendeleyev Ridge to the continental shelf near Alaska. The streamlines provide better definition of the anticyclonic AW circulation in the Beaufort Gyre while flow remains less than $1 \mathrm{~cm} / \mathrm{s}$ in most locations. This depiction of the AW flow resembles the time-mean circulation from 2010 through 2017 discussed in Section 3.2.

The AW flow in January 2014 is consistent with the pathways in January 2010. The meandering positions of the mid basin recirculations are discernible. The AW current speed is lower in most locations compared to January 2010 and January 2006. 

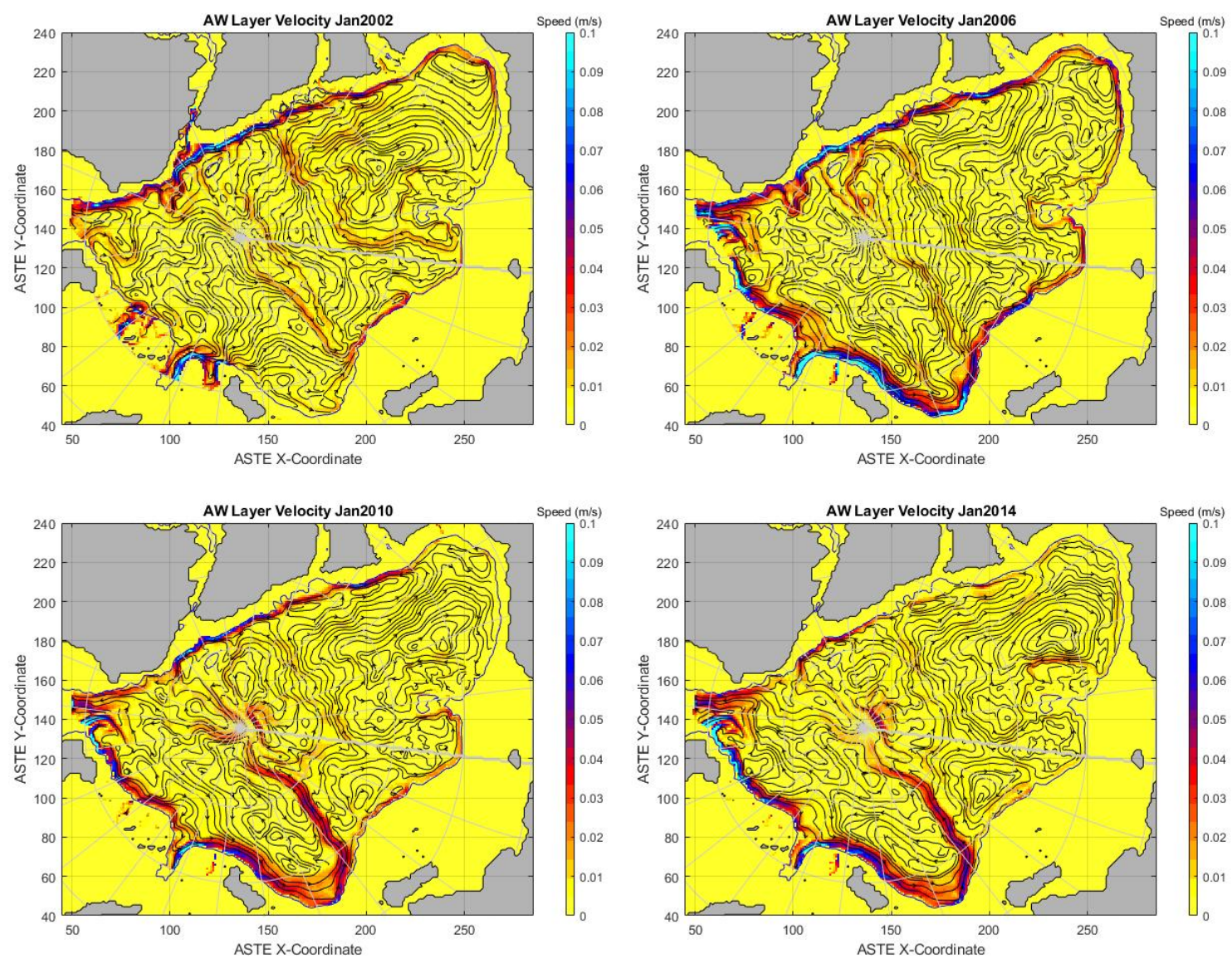

Figure 3-15: Monthly mean AW Layer $\left.\left(1028.2 \mathrm{~kg} / \mathrm{m}^{3}\right)-1028.9 \mathrm{~kg} / \mathrm{m}^{3}\right)$ velocity at four year intervals beginning in January 2002 for grid locations where both AW bounding isopycnals exist. Color shading identifies the AW speed while direction is indicated with streamlines. The $500 \mathrm{~m}$ bathymetry contour is indicated in blue.

One of the notable differences in the flow field between January 2002 and January 2006 is the AW flow direction along the Lomonsov Ridge. Figure 3-16 shows the AW grid-relative flow direction of the AW as a function of time and space along the Lomonosov Boundary Current contour. At the top of the figure, letters correspond to locations where the contour crosses subbasins. These locations are identified on the contour in Figure 2-3. Beginning at Fram Strait, marked with an 'A', there are annual voids of data marked by dark purple, which are the result of the top AW bounding isopycnal, $1028.2 \mathrm{~kg} / \mathrm{m}^{3}$, periodically outcropping along this segment of the contour. The top isopycnal is no longer outcropping by location 'B', the transition from subbasin NFMAB to NMNB, which is near where AW turns North of Svalbard into the AO.

For portions of the contour segment between Svalbard and Franz Josef Land, from 'B' to 
'C', a change in AW grid-relative direction occurs during 2003 where yellow colors (positive, anticyclonic circulation toward Fram Strait) transition to primarily green and blue shades (negative, cyclonic circulation toward the Laptev Sea). This change also occurs in segment 'C' to 'D', between Franz Josef Land and the Laptev Sea, around the same time.

Focusing on the flow along the Lomonosov Ridge between the Eurasian continental shelf and the pole, which can be identified as the region between subbasin transition locations 'D' and 'E', a change of AW flow direction occurs beginning in approximately 2004 and ending in 2008. The grid relative angle changes between 2004 and 2008 from negative angles (blue and aqua), which represents flow toward the Eurasian continental shelf, to positive angles (yellow), which represents flow toward the pole and North America. This direction change was seen in Figure 3-15 when streamlines flip directions for this section of the Lomonosov Ridge between the depictions for January 2002 and January 2006. The slope of this transition yields an estimate of the transition speed occurring along the ridge which is flipping the direction of the AW flow. This speed is estimated as roughly $1.4 \mathrm{~cm} / \mathrm{s}$ which is close in value to the minimum mean AW Layer speeds for the Lomonosov Boundary Current contour shown in Figure 3-13.

Concurrent with the direction change along the Lomonosov Ridge is an increase in the AW speed which is displayed at the bottom of Figure 3-16. Prior to the direction change, the speed in this region was less than $2 \mathrm{~cm} / \mathrm{s}$. After the AW flow direction flips, velocities greater than $4 \mathrm{~cm} / \mathrm{s}$ occur. 

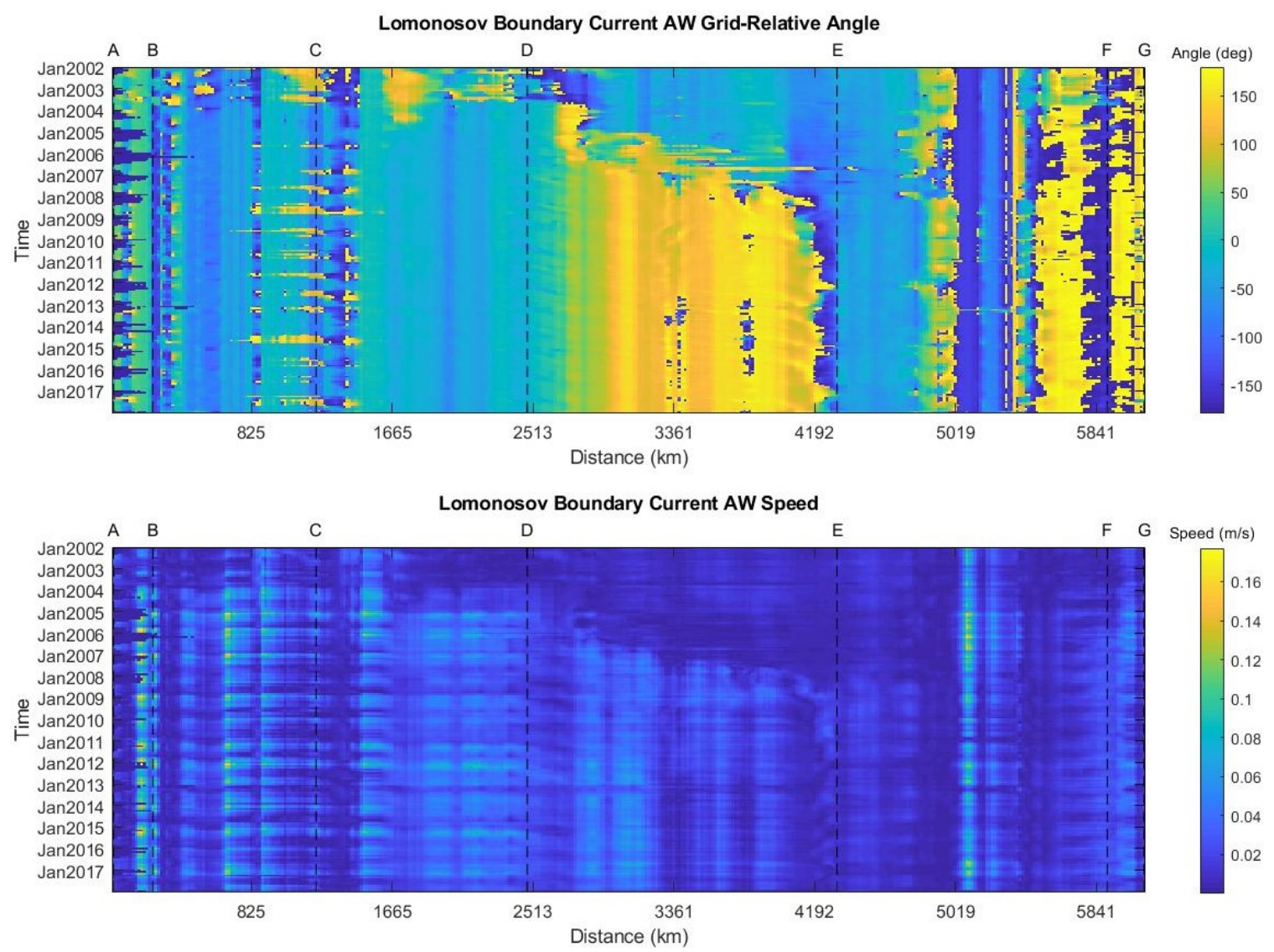

Figure 3-16: Top: The grid-relative AW Layer velocity angle along the Lomonosov Boundary Current contour as a function of time (y-axis) and space (x-axis). The angle definitions are as follows: $0^{\circ}$ is grid-relative East, $90^{\circ}$ is grid-relative North, $180^{\circ}$ or $-180^{\circ}$ is grid-relative West, and $-90^{\circ}$ is grid-relative South. Vertical dashed lines show subbasin transitions along the contour with labels on the top x-axis corresponding to the locations on the contour identified in Figure 2-3. Bottom: The AW speed along the contour as a function of time and space.

These results show that a surge of AW enters the AO in ASTE from Fram Strait and the Barents Sea in 2004. This AW alters the direction of AW boundary current along the contour and increases the AW current speed as it moves into the Laptev Sea and later along the Lomonosov Ridge. A new quasi-steady-state for the AW Layer where the direction and speed of AW is consistent in time and with previous investigations [1, 2] begins by 2010 .

\subsection{Atlantic Water Space-Time Variability}

The mean AW Layer temperature, $\Theta_{a v}$, increases over the duration of ASTE output, Figure 3-17. The increase in temperature commences with the surge of AW discussed in the previous section which increases the boundary current speed and reverses the direction of the flow 
along the Lomonosov Ridge. In January 2002, the warmest AW is near Fram Strait with layer temperatures exceeding approximately $1.5^{\circ} \mathrm{C}$ along the continental shelf north of Svalbard and Franz Josef Land. In 2006, AW temperatures greater than $1.5^{\circ} \mathrm{C}$ advanced cyclonically into the AO reaching the St. Anna Trough and the continental shelf near the Laptev Sea. AW Layer temperatures greater than $1.5^{\circ} \mathrm{C}$ then extend along the Lomonosov Ridge and cross into the Makarov Basin on the Eurasian side of the AO up to the pole in January 2010. The surge of warm AW surrounds cooler water, with temperatures near $1^{\circ} \mathrm{C}$, in the Amundsen Basin away from the Lomonosov Ridge and the continental shelf. By January 2014 , this cooler water has warmed to around $1.5^{\circ} \mathrm{C}$ as the heat is spread to the mid basin and the magnitude of the temperature gradient between the shelf/ridge and the mid basin water has decreased. The warm $\mathrm{AW}$ water near $1.5^{\circ} \mathrm{C}$ has also advanced to the Canadian Archipelago and mid Makarov Basin by this time. 

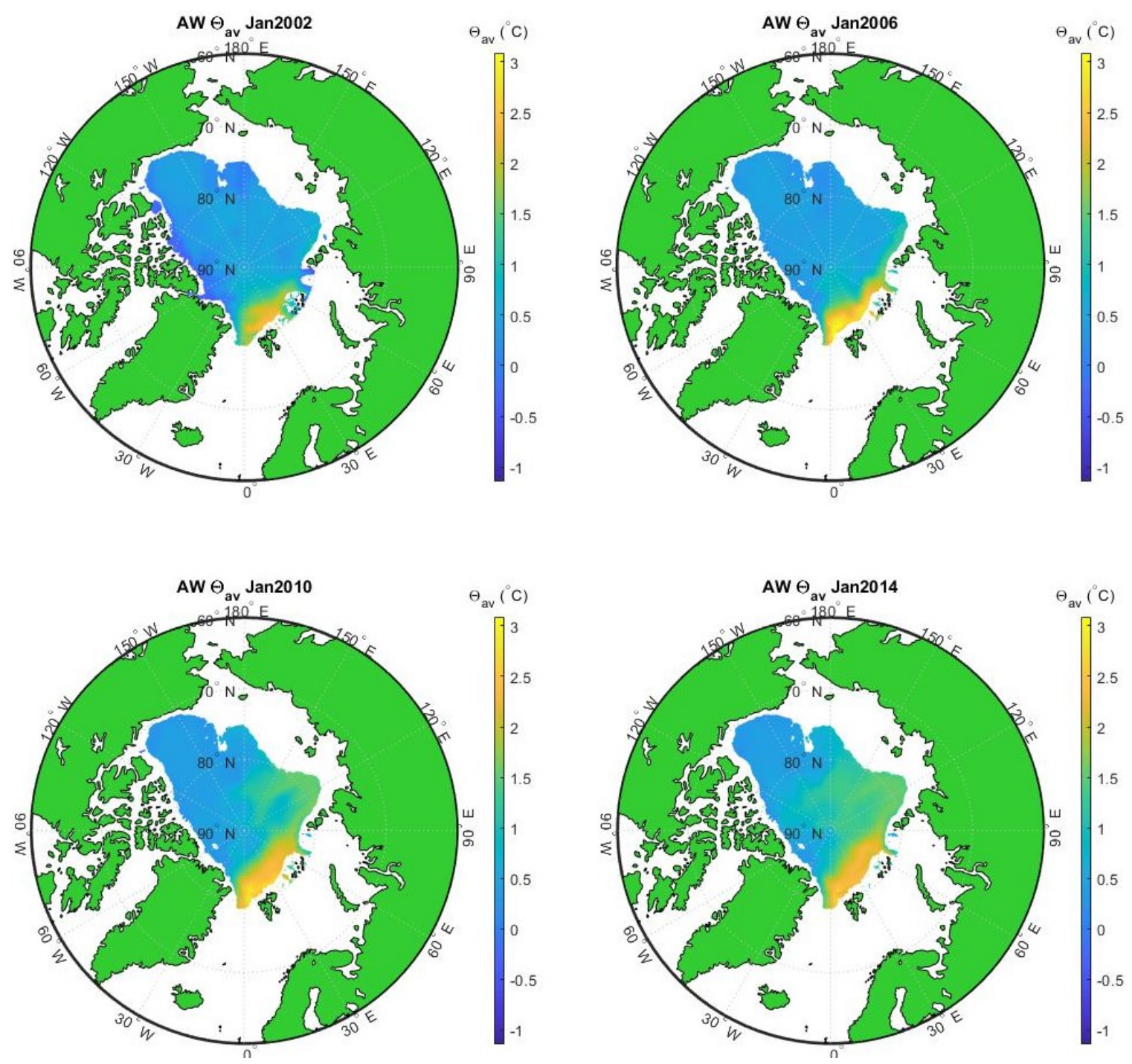

Figure 3-17: Monthly mean AW Layer potential temperature, $\Theta_{a v}$, at four year intervals for the duration of the ASTE output. Only ASTE grid locations with both upper and lower AW bounding isopycnals are plotted.

At the beginning of the model run (January 2002) the thickest AW Layer, approximately $700 \mathrm{~m}$, is in the Laptev Sea, Figure 3-18. Throughout much of the AO, the AW Layer was between $300 \mathrm{~m}$ and $500 \mathrm{~m}$. Areas with the thinnest AW Layer, where both bounding isopycnals exist, were near land (e.g. surrounding Franz Josef Land and the Canadian Archipelago with an extension toward Nares Strait). In January 2006, the thickest AW Layer was north of Svalbard and Franz Josef Land nearest the continental shelf with thickness values near $700 \mathrm{~m}$. In the water space surrounding Franz Josef Land and near the Nares Strait, the deeper AW bounding isopycnal grounded and therefore the shading in the figure has moved toward the interior of the AO. Over time, the region of thick AW Layer 
( $>600 \mathrm{~m}$ ) extended from Fram Strait cyclonically along the continental shelf from Svalbard to the Laptev Sea and followed the Lomonosov Ridge. The thickening in these areas result in a relatively thinner AW Layer, approximately $400 \mathrm{~m}$, in the mid Amundsen Basin. This pattern was seen in the same region for AW $\Theta_{a v}$ during January 2006. The mid Amundsen Basin AW Layer thickens to approximately $500 \mathrm{~m}$ by January 2014. The area of thicker AW Layer spreads over the Lomonosov Ridge and into the Makarov and Canada Basin. The AW Layer is generally thicker, as well as warmer, on the Eurasian side of the AO compared to the North American side.
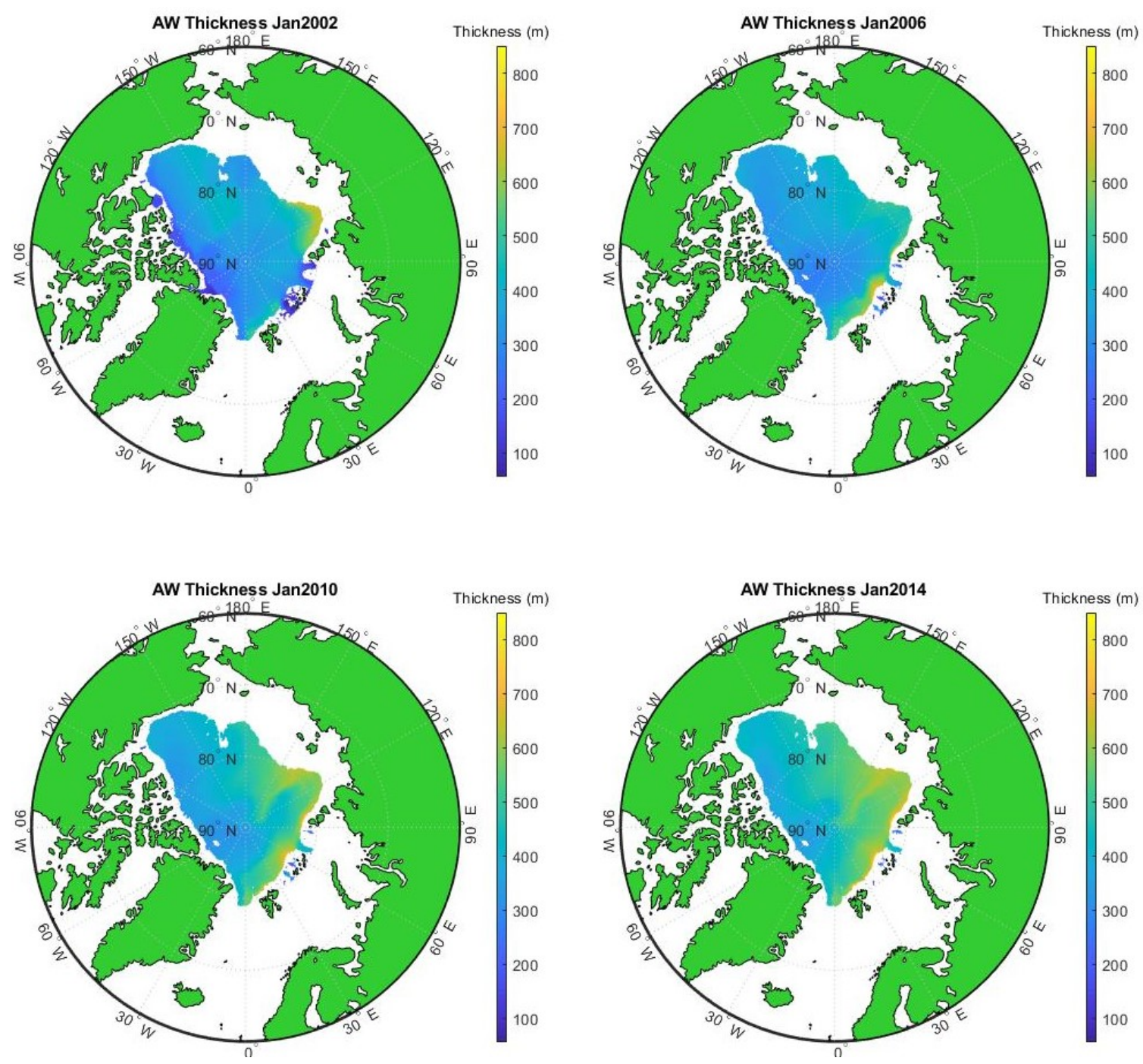

Figure 3-18: Monthly mean AW Layer thickness at four year intervals for the duration of the ASTE output. Only ASTE grid locations where both upper and lower isopycnals exist are plotted. 
Maps of the depth of the $1028.2 \mathrm{~kg} / \mathrm{m}^{3}$ isopycnal, Figure 3-19, show that the top of the AW Layer is shoalest at Fram Strait $(<20 \mathrm{~m})$ and gradually becomes deeper along the major AW pathways. The upper bounding isopycnal is deepest in the Beaufort Gyre of the Canada Basin where depths are greater than $200 \mathrm{~m}$. This is likely the result of downwelling associated with Ekman pumping due to the the Beaufort High as well as the addition of relatively fresh Pacific Water entering from Bering Strait above the AW. Unlike AW $\Theta_{a v}$ and AW thickness, dependence on geographic features, such as the Lomonosov Ridge, is not seen in the depth of the $1028.2 \mathrm{~kg} / \mathrm{m}^{3}$ surface. Time-evolving, spatial patterns in the isopycnal depth are not as obvious as those for AW $\Theta_{a v}$ or layer thickness. Shoaler isopycnal depths near Fram Strait do gradually extend over time where AW recirculates, and north of Svalbard. The overall pattern remains the same over time with shallower isopycnal depths closest to AW inflow areas. 

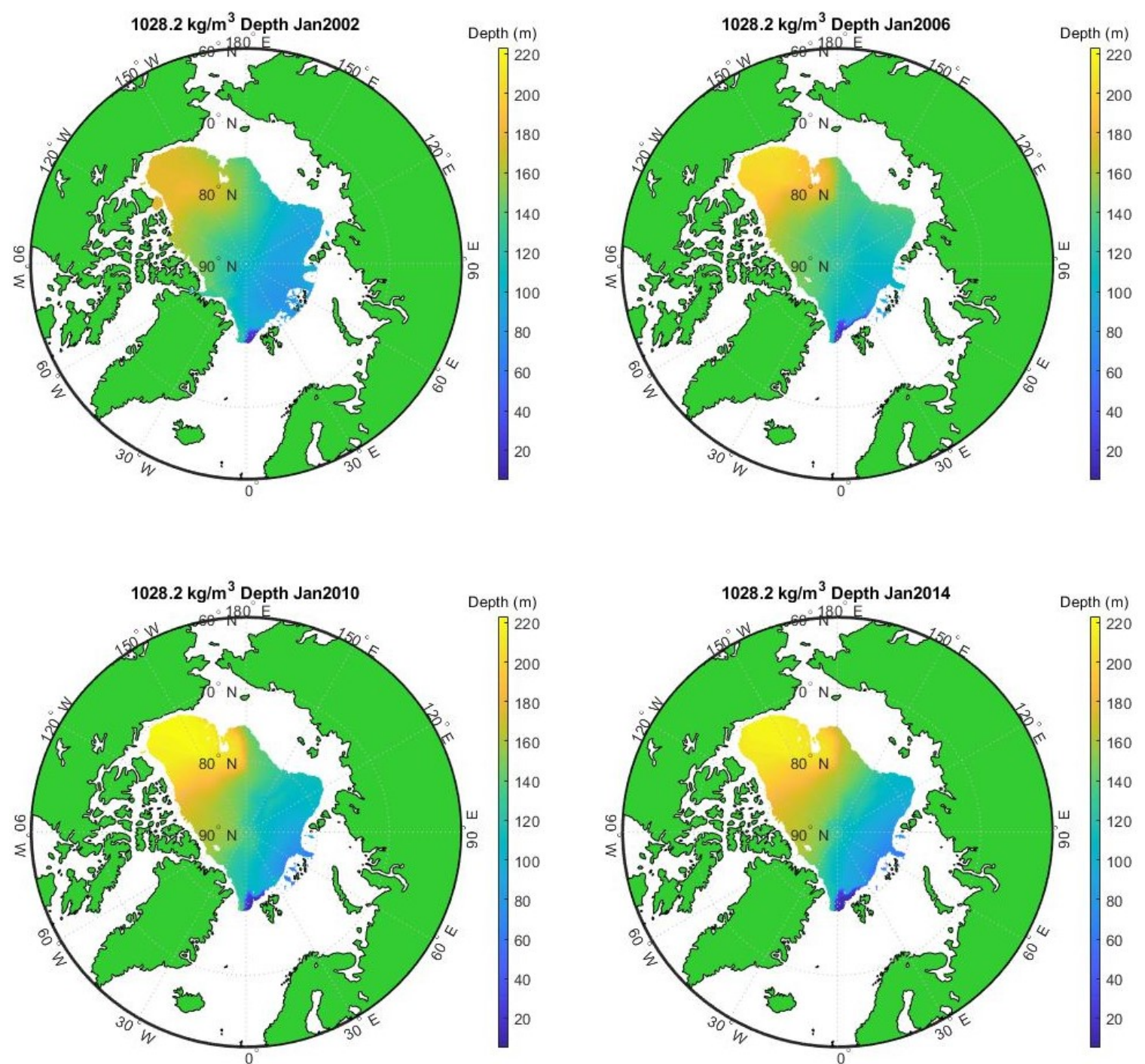

Figure 3-19: Monthly mean $1028.2 \mathrm{~kg} / \mathrm{m}^{3}$ isopycnal depth at four year intervals for the duration of the ASTE output. Only ASTE grid locations where both upper and lower isopycnals exist are plotted.

The lower AW bounding isopycnal, $1028.9 \mathrm{~kg} / \mathrm{m}^{3}$, must be responsible for the AW Layer thickness time and spatial evolution, Figure 3-20. The bottom isopycnal is deepest in the Laptev Sea during January 2002 with depths greater than $700 \mathrm{~m}$ while the shoalest isopycnal depths, less than $200 \mathrm{~m}$, are in the vicinity of Franz Josef Land and along the Canadian Archipelago. An elongated area where $1028.9 \mathrm{~kg} / \mathrm{m}^{3}$ isopycnal depths are less than 300 m stretches toward the Nares Strait between Greenland and Ellesmere Island which has a sill depth of $230 \mathrm{~m}$ [5]. In January 2006, the deepest $1028.9 \mathrm{~kg} / \mathrm{m}^{3}$ isopycnal depths are now located near Franz Josef Land $(\sim 800 \mathrm{~m})$ and these depths extend cyclonically into the Laptev Sea and along the Lomonosov Ridge by January 2010 resulting in an area of 
relatively shallower isopycnal depths in the mid Amundsen Basin. By January 2014, the areas with depths greater than $700 \mathrm{~m}$ extend into the Makarov Basin and Canada Basin with the deepest values near the continental shelf on the Eurasian side of the basins.
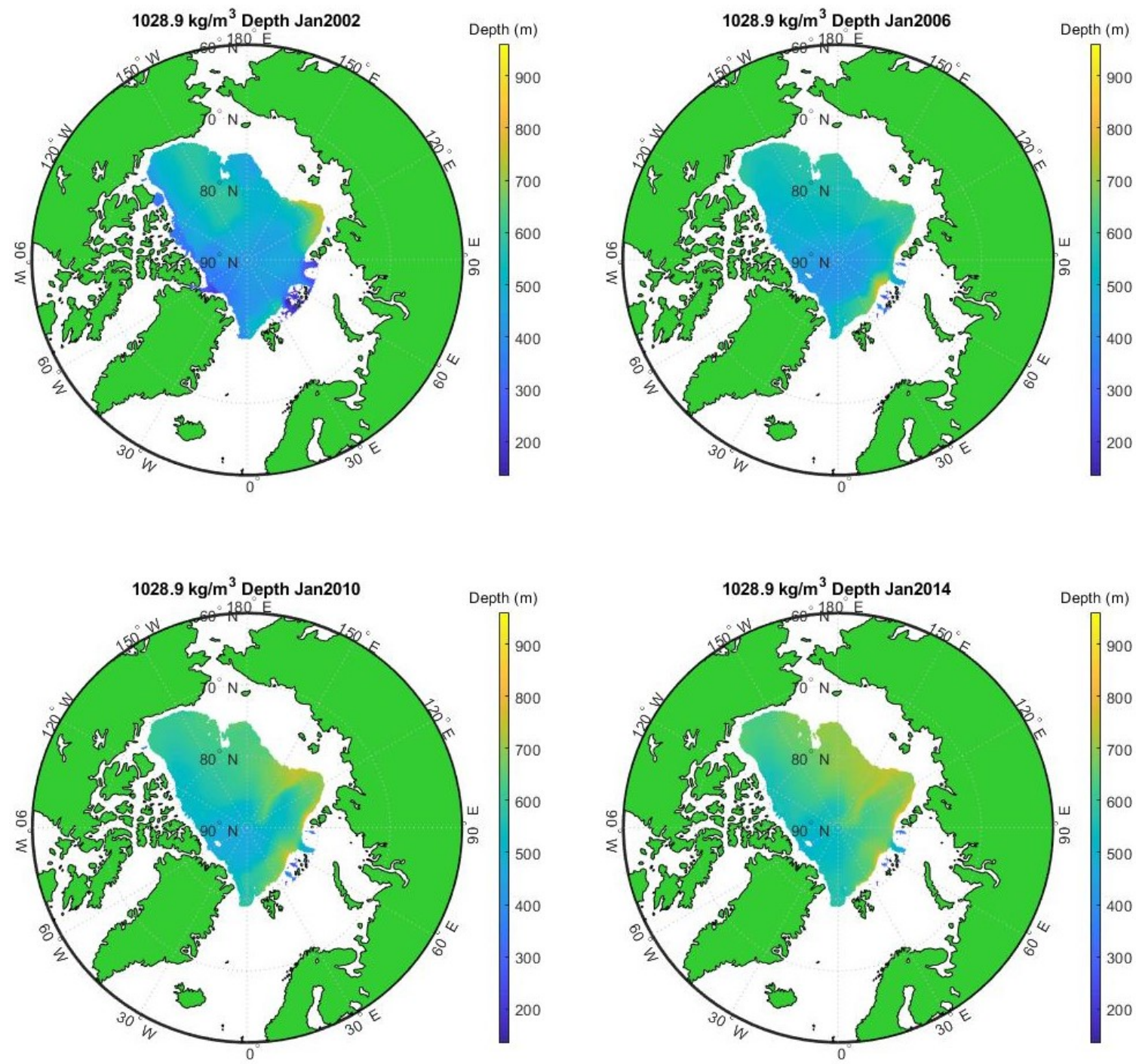

Figure 3-20: Monthly mean $1028.9 \mathrm{~kg} / \mathrm{m}^{3}$ isopycnal depth at four year intervals for the duration of the ASTE output. Only ASTE grid locations where both upper and lower isopycnals exist are plotted.

AW properties along the Lomonosov Boundary Current and Circumpolar Boundary Current contours show an abrupt increase in AW temperature (Figure 3-21) and AW thickness (Figure 3-22) beginning in 2004/2005 at Fram Strait. Seasonal fluctuations of AW properties at Fram Strait are evident for both parameters, but in 2004/2005 the warming and thickening are seen to extend east along bathymetric contours between 'B' and ' $\mathrm{C}$ ' which is the segment between Svalbard and Franz Josef Land where AW enters the AO proper rather 
than recirculating back through Fram Strait. This change is more abrupt between segment 'C' to 'D' from Franz Josef Land to the Laptev Sea and occurs later in 2005. The AW Layer temperature shifts from less than $1{ }^{\circ} \mathrm{C}$ to approximately $1.5^{\circ} \mathrm{C}$, and the AW Layer thickness changes from less than $300 \mathrm{~m}$ to greater than $500 \mathrm{~m}$. The two contours split between ' $\mathrm{D}$ ' to 'E'. Location 'E' is where the Circumpolar Boundary Current contour crosses the Lomonosov Ridge into the Makarov Basin whereas the Lomonosov Boundary Current contour turns and parallels the Lomonosov Ridge and 'E' marks the transition from EMAB to NMAB (near the North Pole). Rapid AW Layer warming and AW Layer thickening continue along these segments from 2006 to 2008. The slope of the transition in this segments indicates that the signal moved along the contour at approximately $2 \mathrm{~cm} / \mathrm{s}$. This speed is similar to the mean AW boundary current contour speeds seen in Figures 3-13 and 3-14.

Beyond location 'E', the surge is not seen along the Lomonosov Boundary Current contour to its termination at Fram Strait. This is likely a result of AW crossing the Lomonosov Ridge into the Makarov Ridge or turning toward Fram Strait, as seen in the time-mean circulation, rather than completely paralleling the Lomonosov Ridge. On the other hand, the Circumpolar Boundary Current contour does retain the surge signal beyond location 'E' into the Makarov Basin up to approximately the Mendeleyev Ridge separating the Makarov and Canada Basin at contour location 'F'. The already reduced AW flow which crossed the Lomonosov Ridge turns at the Mendeleyev Ridge rather crossing the Mendeleyev Ridge into the Canada Basin as the Circumpolar Boundary Current contour does. 

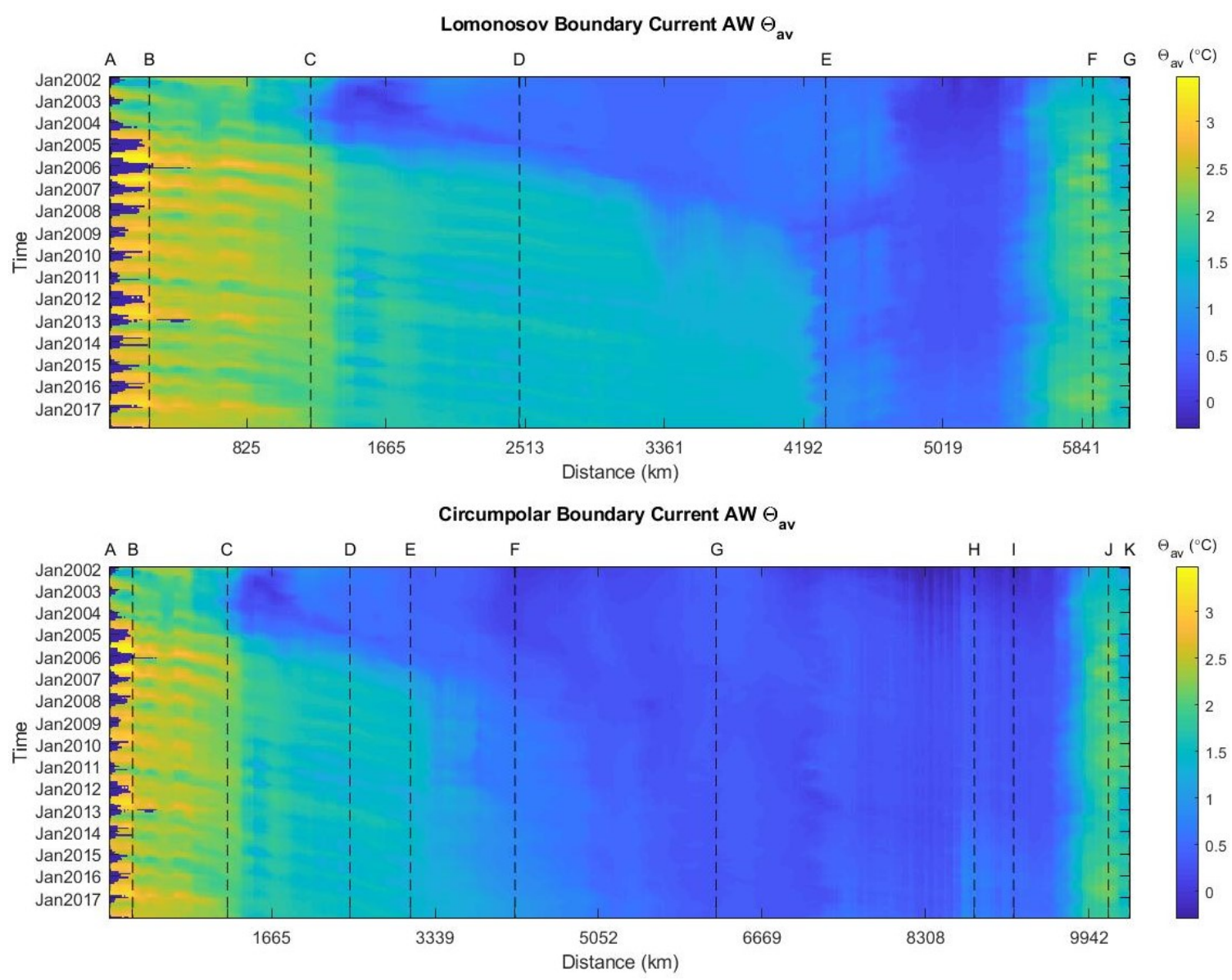

Figure 3-21: Top: Time versus distance along the Lomonosov Boundary Current contour of AW Layer potential temperature, $\Theta_{a v}$. Bottom: Time versus distance along the Circumpolar Boundary Current contour of AW llyer potential temperature, $\Theta_{a v}$. Vertical dashed lines indicate subbasin transition locations with letters on the top axis corresponding to locations identified in Figures 2-3 and 2-4. The distance along each contour is identified on the bottom axis. 

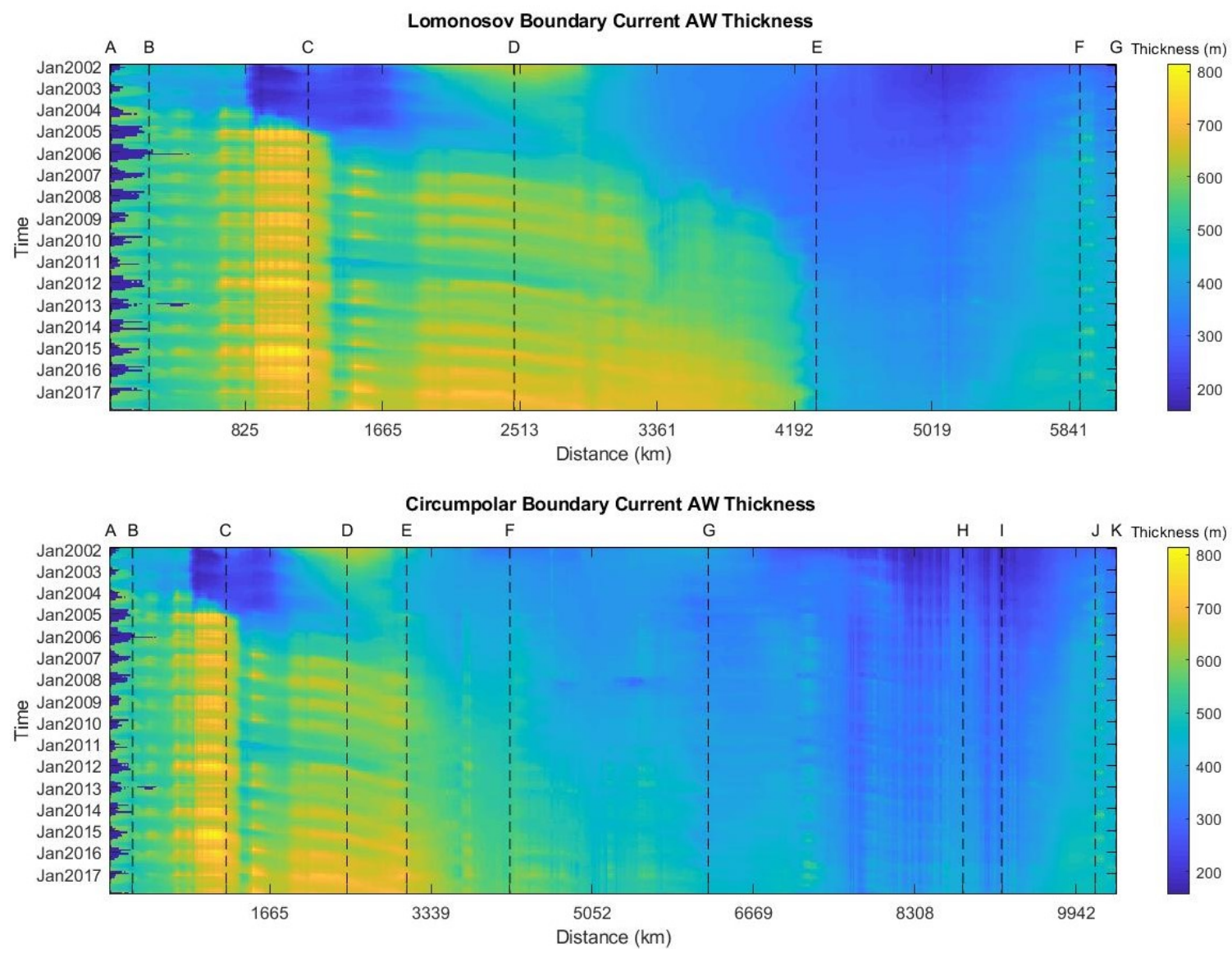

Figure 3-22: Top: Time versus distance along the Lomonosov Boundary Current contour of AW Layer thickness. Bottom: Time versus distance along the Circumpolar Boundary Current contour of AW Layer thickness. Vertical dashed lines indicate subbasin transition locations with letters on the top axis corresponding to locations identified in Figures 2-3 and 2-4. The distance along each contour is identified on the bottom axis.

The surge seen in the AW thickness along both boundary current contours is not seen in the $1028.2 \mathrm{~kg} / \mathrm{m}^{3}$ isopycnal depth (Figure 3-23). Thus, the surge in AW thickness is the result of the lower bounding isopycnal, $1028.9 \mathrm{~kg} / \mathrm{m}^{3}$, increasing in depth over time (Figure 3-24). Although the surge does not influence the upper isopycnal, a gradual deepening is seen in the Canada Basin (surrounding location ' $G$ ' for the Circumpolar Boundary Current contour) over the duration of ASTE output where depths begin around $200 \mathrm{~m}$ or less and eventually exceed $200 \mathrm{~m}$.

The increased lower isopycnal depths associated with the surge are responsible for the resulting AW thickness changes. Focusing at location 'C' near Franz Josef Land, the 1028.9 $\mathrm{kg} / \mathrm{m}^{3}$ isopycnal depth increases from less than $400 \mathrm{~m}$ to greater than $700 \mathrm{~m}$ in 2004/2005. The increasing bottom AW bounding isopycnal depth associated with the surge follows both 
boundary current contours as was previously described for AW $\Theta_{a v}$ and AW thickness.

With the surge following the AW flow described by the time-mean and time-varying circulation from 2010-2017 and at speeds similar to the mean AW boundary current speed, the spatial changes to the AW properties appear to occur mainly through advection.
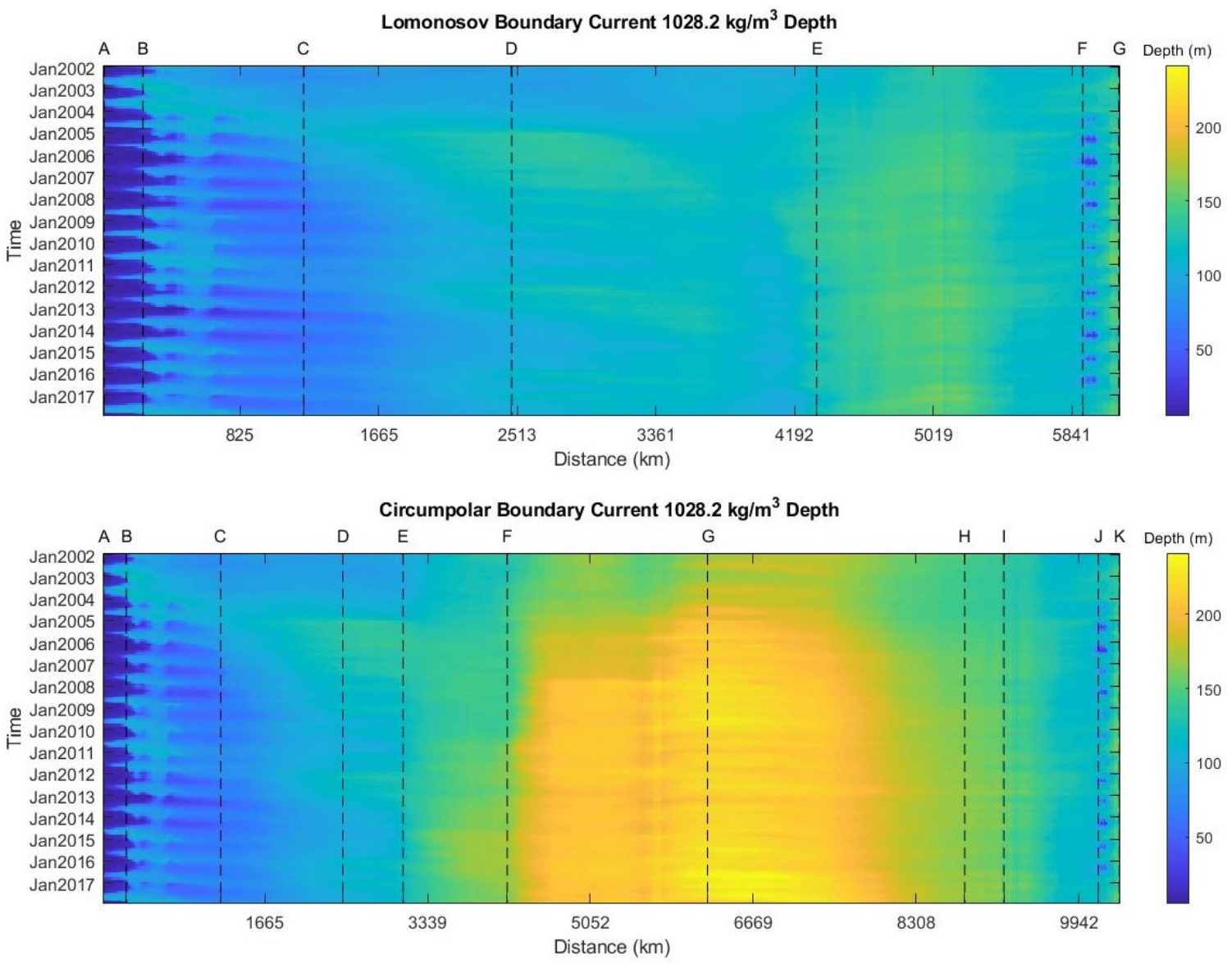

Figure 3-23: Top: Time versus distance along the Lomonosov Boundary Current contour of the AW upper boundary, $1028.2 \mathrm{~kg} / \mathrm{m}^{3}$, depth. Bottom: Time versus distance along the Circumpolar Boundary Current contour of the AW upper boundary, $1028.2 \mathrm{~kg} / \mathrm{m}^{3}$, depth. Vertical dashed lines indicate subbasin transition locations with letters on the top axis corresponding to locations identified in Figures 2-3 and 2-4. The distance along each contour is identified on the bottom axis. 

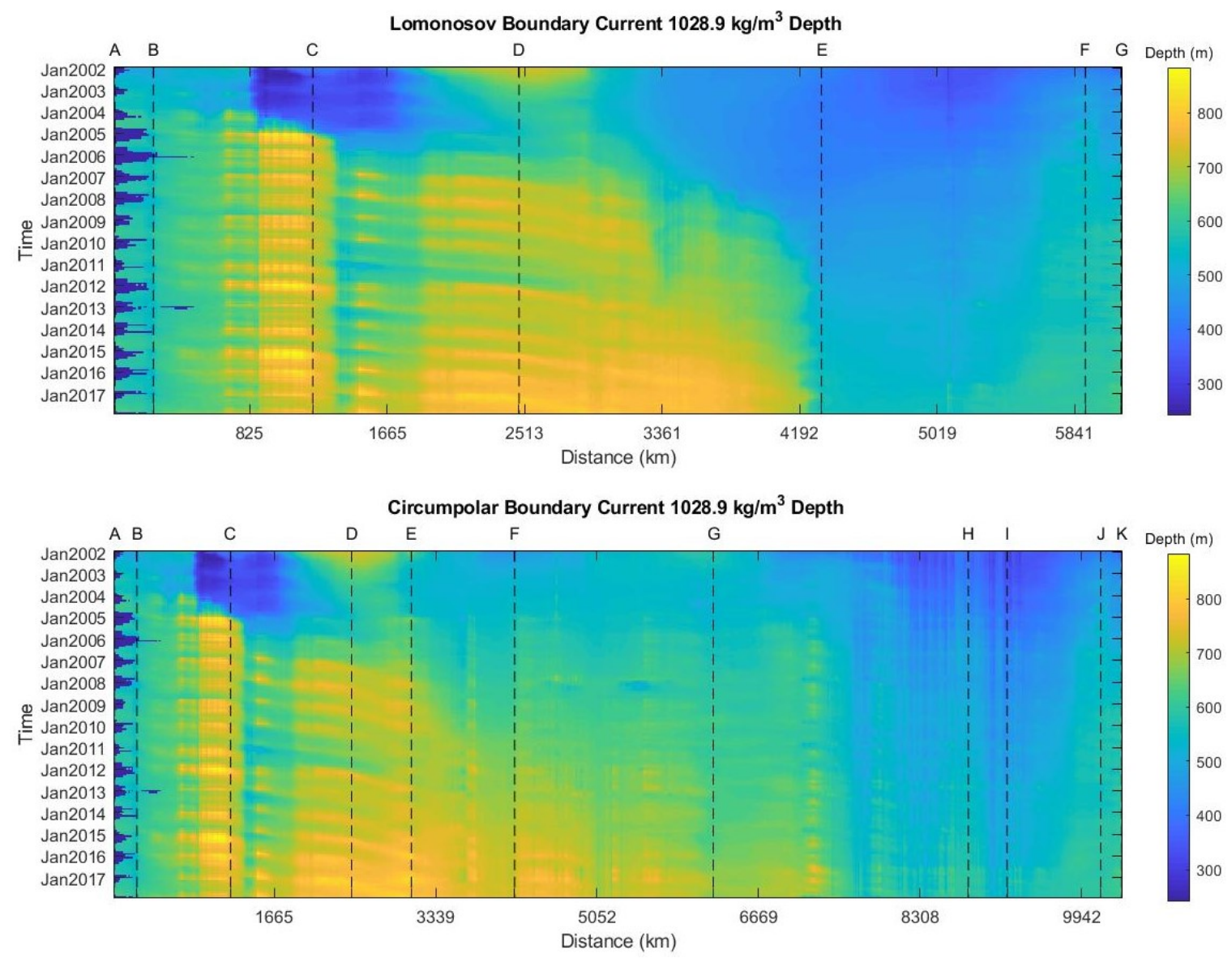

Figure 3-24: Top: Time versus distance along the Lomonosov Boundary Current contour of the AW lower boundary, $1028.9 \mathrm{~kg} / \mathrm{m}^{3}$, depth. Bottom: Time versus distance along the Circumpolar Boundary Current contour of the AW lower boundary, $1028.9 \mathrm{~kg} / \mathrm{m}^{3}$, depth. Vertical dashed lines indicate subbasin transition locations with letters on the top axis corresponding to locations identified in Figures 2-3 and 2-4. The distance along each contour is identified on the bottom axis.

To assess how well ASTE is representing the AW Layer in the real ocean, comparisons of the monthly mean ASTE output and observations (CTDs and ITPs) were made in many of the subbasins shown in Figure 2-2. This thesis presents results for two subbasins: the EMNB and NMCB. The EMNB subbasin is near the AW inflow areas and contains AW from both Fram Strait and the Barents Sea. On the opposite side of the AO, the NMCB subbasin is furthest from the AW sources. The mid subbasins are selected since they are larger and contain more observations than their neighboring circumpolar subbasins. The AW parameters for the EMNB subbasin are presented first.

As indicated in the bottom right panel of Figure 3-25, the number of observations in subbasin EMNB is limited with a total of 615 ITP and CTD water column profiles in 
the database for the 2002-2017 time period compared to the 20,604 observations over the same time period in subbasin NMCB. The plot also shows how the observations are spaced unevenly in time. In the top right panel, the ASTE AW $\Theta_{a v}$ in EMNB is seen to increase over the duration of the model output with a subbasin mean (red line) near $0.7^{\circ} \mathrm{C}$ in 2002 and concluding at $1.7^{\circ} \mathrm{C}$. The fastest increase in model temperature occurs between January 2005 and January 2007 as the AW surge passes. The AW $\Theta_{a v}$ value at the ASTE grid locations closest to the observations, as described in Section 2.8, are plotted as well to test if the observation locations accurately represent the full, area-averaged subbasin mean (red line). These values also suggest an upward trend in $\mathrm{AW} \Theta_{a v}$ values. However, the observed AW layer temperatures, displayed in the bottom left panel, do not show the same increase in temperature. As a result, the difference between the ASTE and observed AW Layer temperatures, or misfits, (top left panel) increase with time which means that ASTE has AW in the EMNB subbasin warming with time more than the observations indicate. 

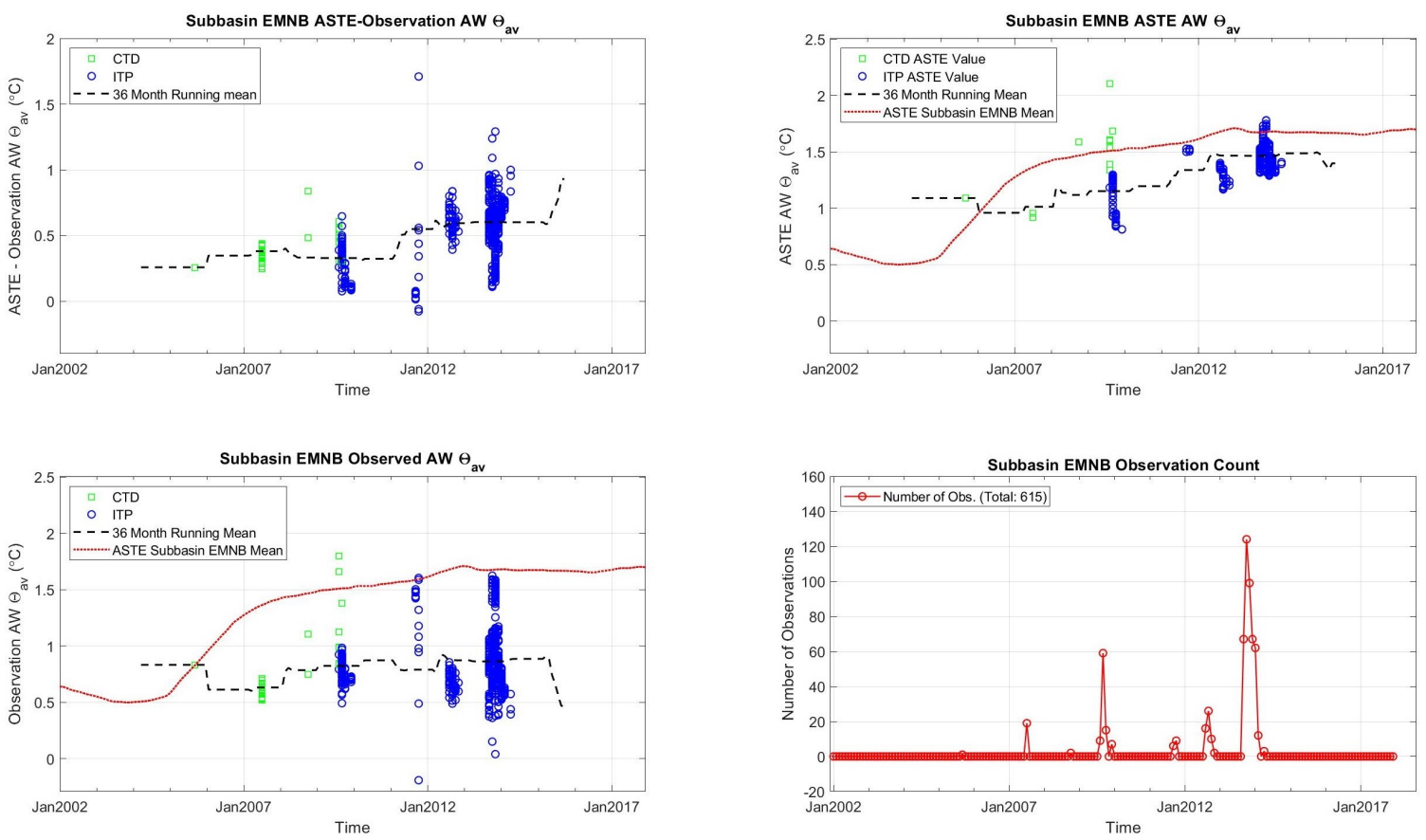

Figure 3-25: Top Left: The difference between the observed (CTD or ITP) AW $\Theta_{a v}$ and the ASTE AW $\Theta_{a v}$ for the closest grid location to the observation at the time of each observation in the EMNB subbasin. A 36 month running mean of the differences is plotted in a black dashed line. Top Right: The ASTE AW $\Theta_{a v}$ for the closest grid location to the observation during the month of the observation. The black dashed line is a 36 month running mean of the ASTE AW $\Theta_{a v}$ values at the nearest grid location to the observation. The red line is the overall subbasin mean ASTE AW $\Theta_{a v}$ value. Bottom Left: The observed AW $\Theta_{a v}$ for CTDs (squares) and ITP (circles). The red line is the overall subbasin mean ASTE AW $\Theta_{a v}$ value. Bottom Right: The number of observations in the EMNB subbasin for each month of ASTE output.

The ASTE AW Layer in subbasin EMNB thickens over the duration of the ASTE output, Figure 3-26. Initial EMNB mean AW thickness values start near $400 \mathrm{~m}$ and conclude above $600 \mathrm{~m}$ by December 2017. AW thickness increases most rapidly from 2005 through 2007 as was the case for ASTE AW $\Theta_{a v}$. The 36 month running mean of ASTE AW thickness for observation grid locations follows the subbasin mean trend but the observed AW thickness values remain relatively steady near $400 \mathrm{~m}$ in the 36 month running mean. A large range of observed AW thickness values exist in the subbasin with the minimum less than $200 \mathrm{~m}$ and the maximum near $560 \mathrm{~m}$. Overall, actual observed AW Layer thickness values in EMNB are less than the ASTE AW Layer thickness with the 36 month running mean of the difference between the ASTE and observed thickness increasing over time. 

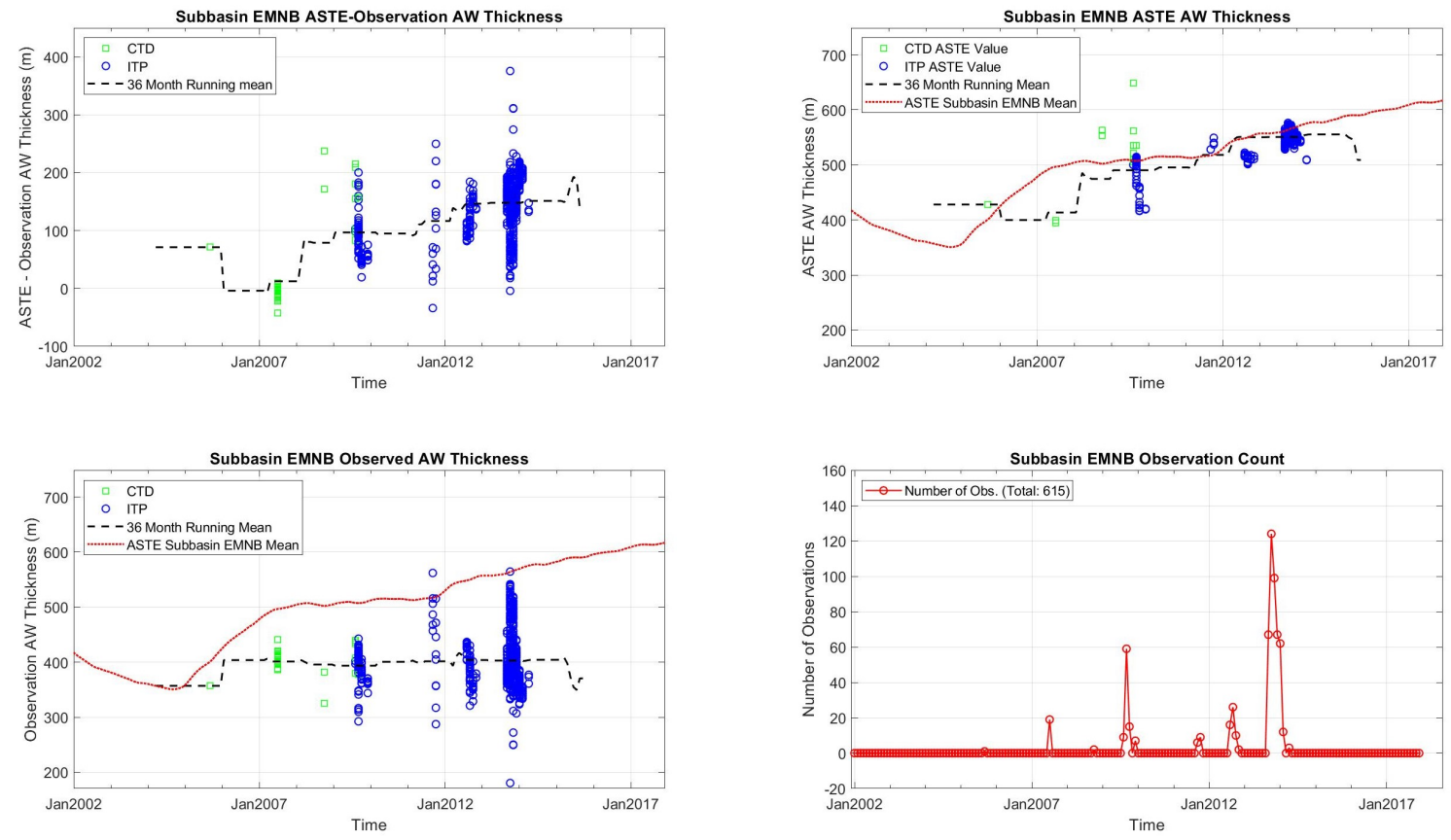

Figure 3-26: Top Left: The difference between the observed (CTD or ITP) AW thickness and the ASTE AW thickness for the closest grid location to the observation at the time of each observation in the EMNB subbasin. A 36 month running mean of the differences is plotted in a black dashed line. Top Right: The ASTE AW thickness for the closest grid location to the observation during the month of the observation. The black dashed line is a 36 month running mean of the ASTE AW thickness values at the nearest grid location to the observation. The red line is the overall subbasin mean ASTE AW thickness value. Bottom Left: The observed AW thickness for CTDs (squares) and ITP (circles). The red line is the overall subbasin mean ASTE AW thickness value. Bottom Right: The number of observations in the EMNB subbasin for each month of ASTE output.

The mean EMNB top AW bounding isopycnal at the beginning of the state estimate period lies at approximately $90 \mathrm{~m}$ depth and increases to $115 \mathrm{~m}$ depth by early 2005 (Figure $3-27)$. In 2005, the mean isopycnal depth begins to steadily decrease. The timing of this transition is the same as the increased warming and thickening in this subbasin. The observation locations in ASTE follow a similar trend and are within $20 \mathrm{~m}$ of the subbasin mean. In comparison, observed $1028.2 \mathrm{~kg} / \mathrm{m}^{3}$ isopycnal depths are all shallower than ASTE and begin around $40 \mathrm{~m}$ with an increase to approximately $60 \mathrm{~m}$ during 2015 . The model misfit decreases with time. 

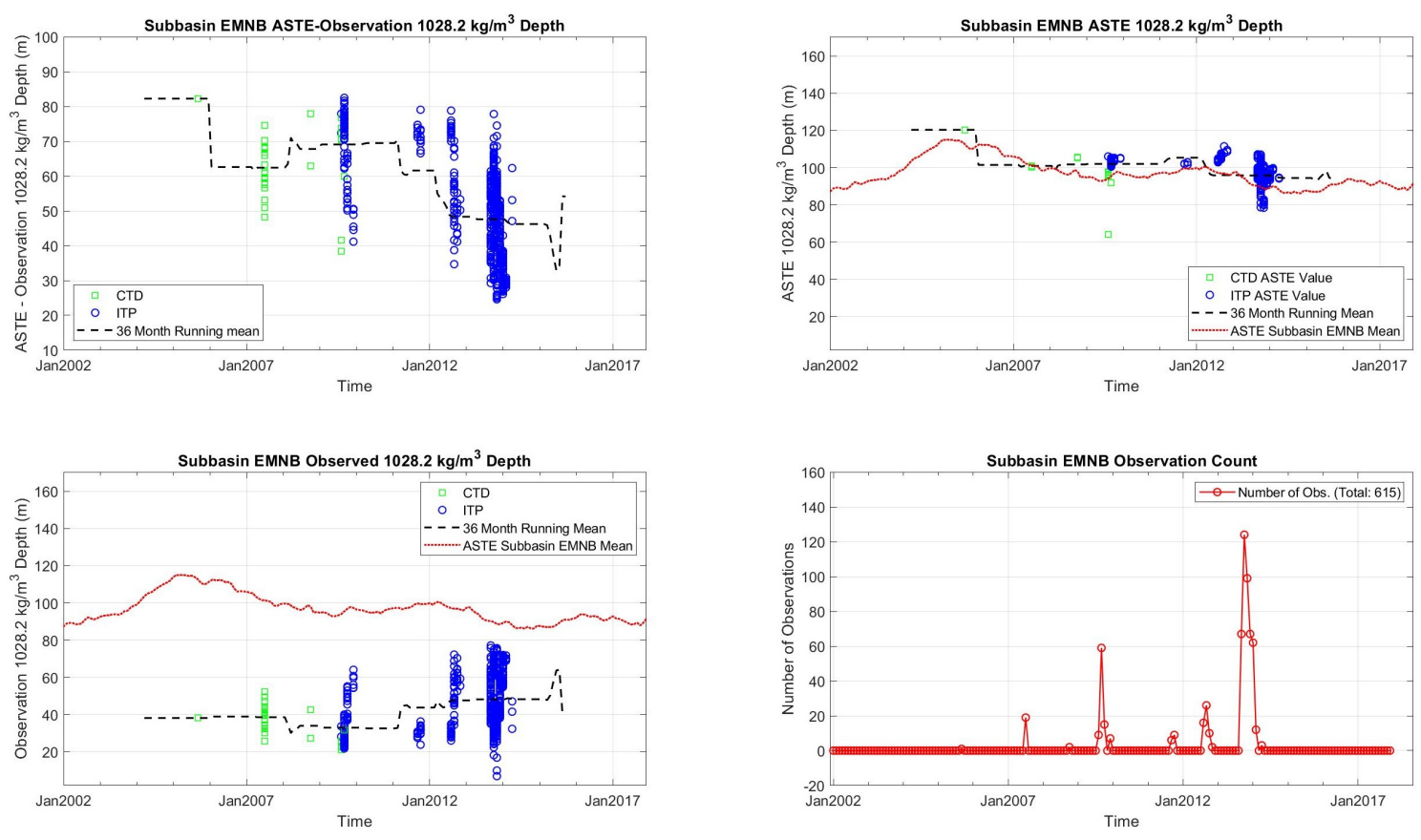

Figure 3-27: Top Left: The difference between the observed (CTD or ITP) $1028.2 \mathrm{~kg} / \mathrm{m}^{3}$ depth and the ASTE $1028.2 \mathrm{~kg} / \mathrm{m}^{3}$ depth for the closest grid location to the observation at the time of each observation in the EMNB subbasin. A 36 month running mean of the differences is plotted in a black dashed line. Top Right: The ASTE $1028.2 \mathrm{~kg} / \mathrm{m}^{3} \mathrm{depth}$ for the closest grid location to the observation during the month of the observation. The black dashed line is a 36 month running mean of the ASTE $1028.2 \mathrm{~kg} / \mathrm{m}^{3}$ depth values at the nearest grid location to the observation. The red line is the overall subbasin mean ASTE $1028.2 \mathrm{~kg} / \mathrm{m}^{3}$ depth value. Bottom Left: The observed $1028.2 \mathrm{~kg} / \mathrm{m}^{3}$ depth for CTDs (squares) and ITP (circles). The red line is the overall subbasin mean ASTE $1028.2 \mathrm{~kg} / \mathrm{m}^{3}$ depth value. Bottom Right: The number of observations in the EMNB subbasin for each month of ASTE output.

The mean AW bottom bounding isopycnal, $1028.9 \mathrm{~kg} / \mathrm{m}^{3}$, for subbasin EMNB in Figure 3-28 follows a similar pattern to the AW Layer mean potential temperature and AW Layer thickness. The ASTE subbasin mean isopycnal depth increases from approximately $450 \mathrm{~m}$ in 2005 to $600 \mathrm{~m}$ in 2007 . The bottom isopycnal increases less rapidly to $700 \mathrm{~m}$ in 2017 . The observation locations in ASTE follow the subbasin mean to deeper depths but the running mean of the observed $1028.9 \mathrm{~kg} / \mathrm{m}^{3}$ depth remains relatively steady at $450 \mathrm{~m}$ for the entirety of the state estimate period. All of the observed lower isopycnal depths are shallower than the subbasin mean ASTE value. There is a $300 \mathrm{~m}$ spread in observed AW bottom bounding isopycnal depths late in 2011 and in 2013 which is not seen in ASTE. It is the deeper depth of the bottom isopycnal in ASTE compared to observations which is resulting in AW thickness discrepancies of the same magnitude $(\sim 100 \mathrm{~m})$ seen in Figure 3-26. 

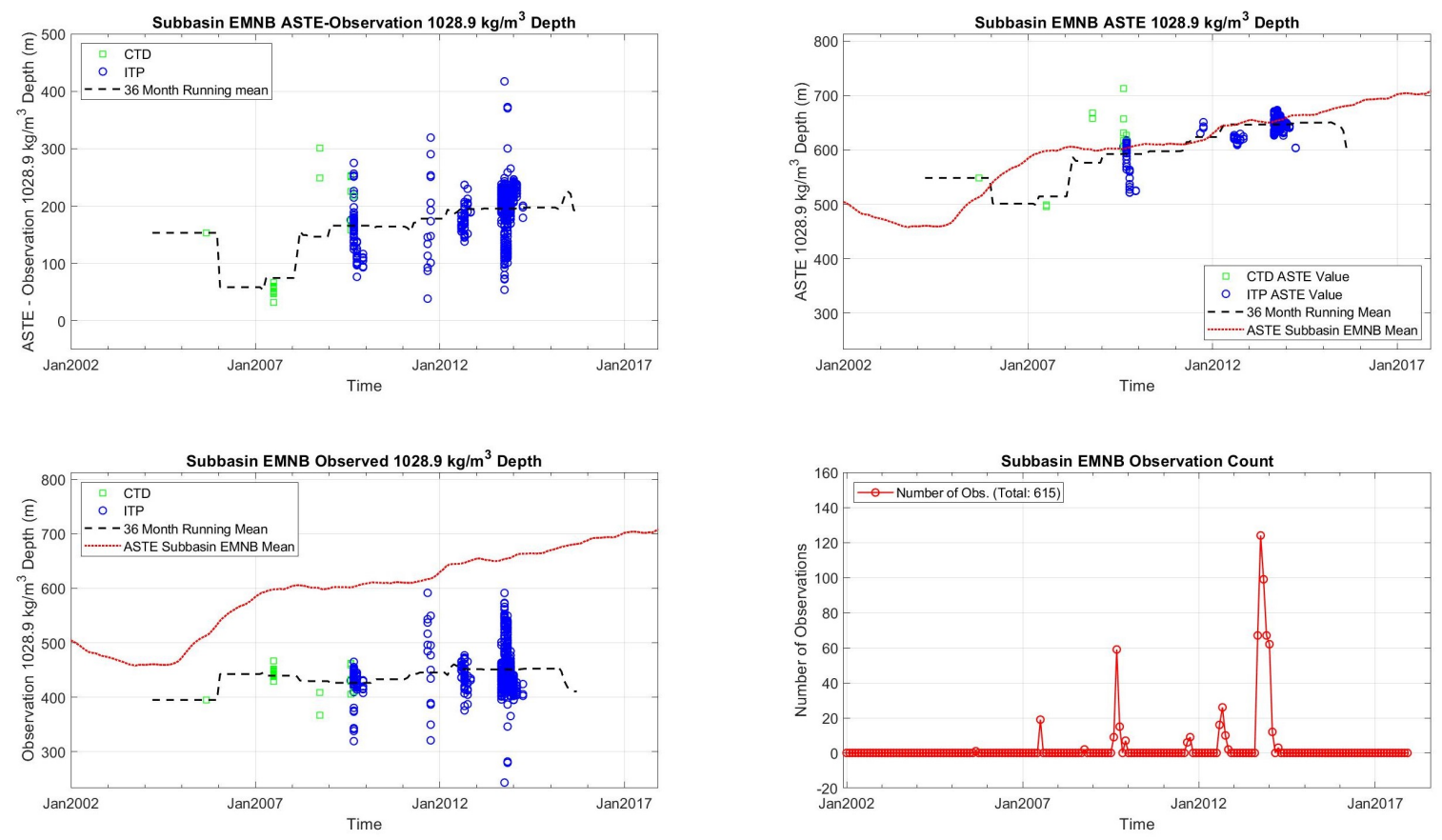

Figure 3-28: Top Left: The difference between the observed (CTD or ITP) $1028.9 \mathrm{~kg} / \mathrm{m}^{3}$ depth and the ASTE $1028.9 \mathrm{~kg} / \mathrm{m}^{3}$ depth for the closest grid location to the observation at the time of each observation in the EMNB subbasin. A 36 month running mean of the differences is plotted in a black dashed line. Top Right: The ASTE $1028.9 \mathrm{~kg} / \mathrm{m}^{3} \mathrm{depth}$ for the closest grid location to the observation during the month of the observation. The black dashed line is a 36 month running mean of the ASTE $1028.9 \mathrm{~kg} / \mathrm{m}^{3}$ depth values at the nearest grid location to the observation. The red line is the overall subbasin mean ASTE $1028.9 \mathrm{~kg} / \mathrm{m}^{3}$ depth value. Bottom Left: The observed $1028.9 \mathrm{~kg} / \mathrm{m}^{3}$ depth for CTDs (squares) and ITP (circles). The red line is the overall subbasin mean ASTE $1028.9 \mathrm{~kg} / \mathrm{m}^{3}$ depth value. Bottom Right: The number of observations in the EMNB subbasin for each month of ASTE output.

The analysis now shifts to the NMCB subbasin on the opposite side of the AO. Similar to the EMNB subbasin, the NMCB subbasin also shows an increase in AW $\Theta_{a v}$ over the duration of ASTE output although smaller in magnitude $\left(\sim 0.3^{\circ} \mathrm{C}\right.$ vs. $\left.\sim 1^{\circ} \mathrm{C}\right)$ and with warming commencing later (January 2011 vs. January 2005). This warming trend persists through the end of the state estimate period in December 2017. The reduced ASTE data set consisting of model output at the times and places of the available observations also indicate there is AW Layer warming within the subbasin. This smaller dataset also indicates there is variability within the subbasin as ASTE layer temperatures at observation sites generally remain within $0.1^{\circ} \mathrm{C}$ of the subbasin mean AW temperature until 2012 when some locations within the subbasin are $0.4^{\circ} \mathrm{C}$ warmer than the subbasin mean. Observed $\mathrm{AW} \Theta_{a v}$ values are generally less than the ASTE values for the entire duration of ASTE output. The 
observations indicate a warming in the subbasin of less than $0.2^{\circ} \mathrm{C}$ from 2004 to 2017 in the 36 month running mean.
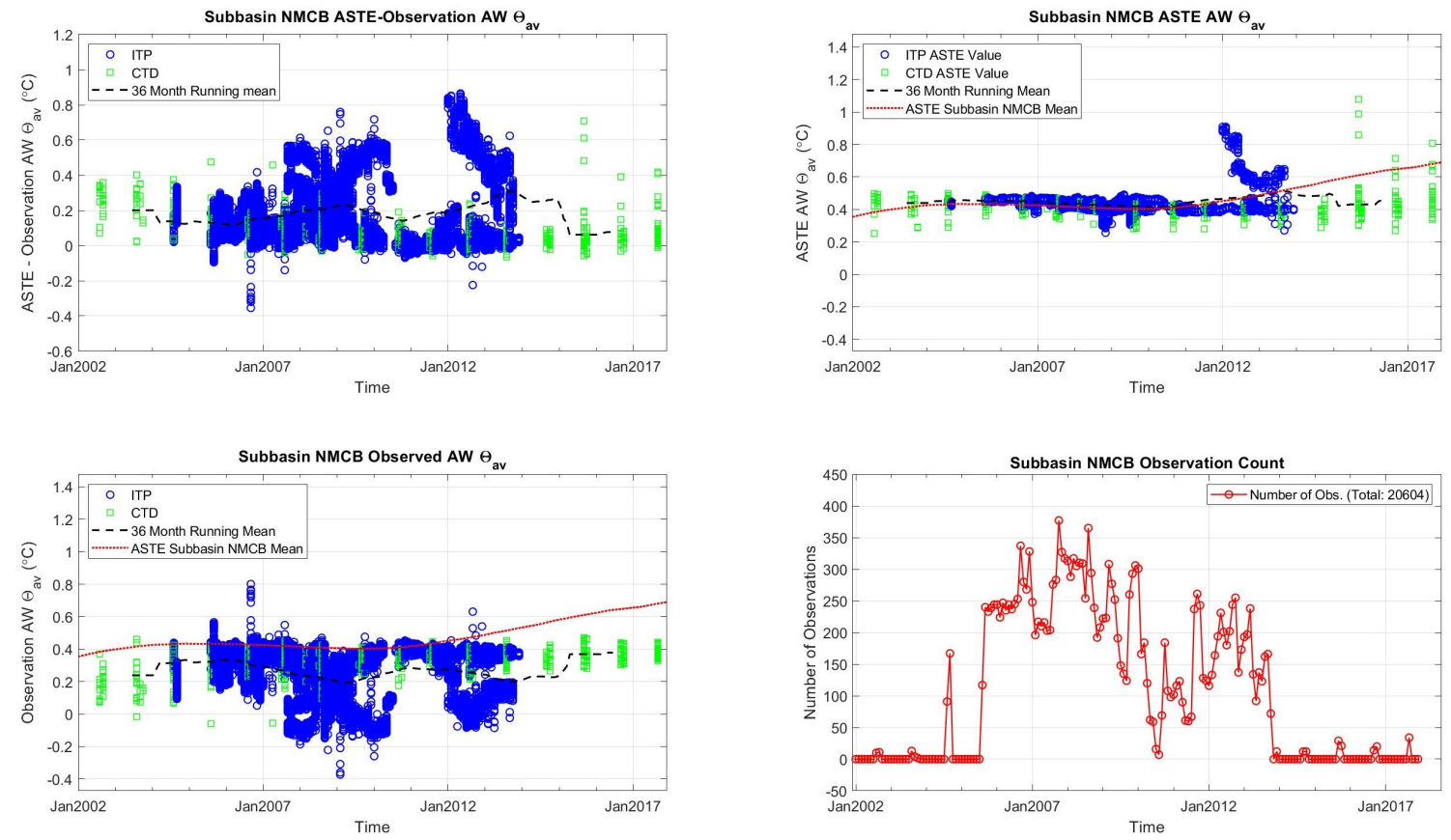

Figure 3-29: Top Left: The difference between the observed (CTD or ITP) AW $\Theta_{a v}$ and the ASTE AW $\Theta_{a v}$ for the closest grid location to the observation at the time of each observation in the NMCB subbasin. A 36 month running mean of the differences is plotted in a black dashed line. Top Right: The ASTE AW $\Theta_{a v}$ for the closest grid location to the observation during the month of the observation. The black dashed line is a 36 month running mean of the ASTE AW $\Theta_{a v}$ values at the nearest grid location to the observation. The red line is the overall subbasin mean ASTE AW $\Theta_{a v}$ value. Bottom Left: The observed AW $\Theta_{a v}$ for CTDs (squares) and ITP (circles). The red line is the overall subbasin mean ASTE AW $\Theta_{a v}$ value. Bottom Right: The number of observations in the NMCB subbasin for each month of ASTE output.

The ASTE NMCB mean AW thickness increases during the state estimate period with a steady increase beginning in 2006 (Figure 3-30) which is earlier than when AW $\Theta_{a v}$ increased in the basin. The 36 month running mean of the observation locations in ASTE follow the subbasin mean AW thickness which starts at $350 \mathrm{~m}$ and increased to just below $450 \mathrm{~m}$ by December 2017. On the other hand, the observed AW thickness remains steady at around $350 \mathrm{~m}$ for the 36 month running mean. This results in an increasing difference between the model and observations during the state estimate period with a thicker AW Layer in ASTE than observations. This difference is approximately $100 \mathrm{~m}$ by December 2017 after being nearly zero early in the state estimate period. 

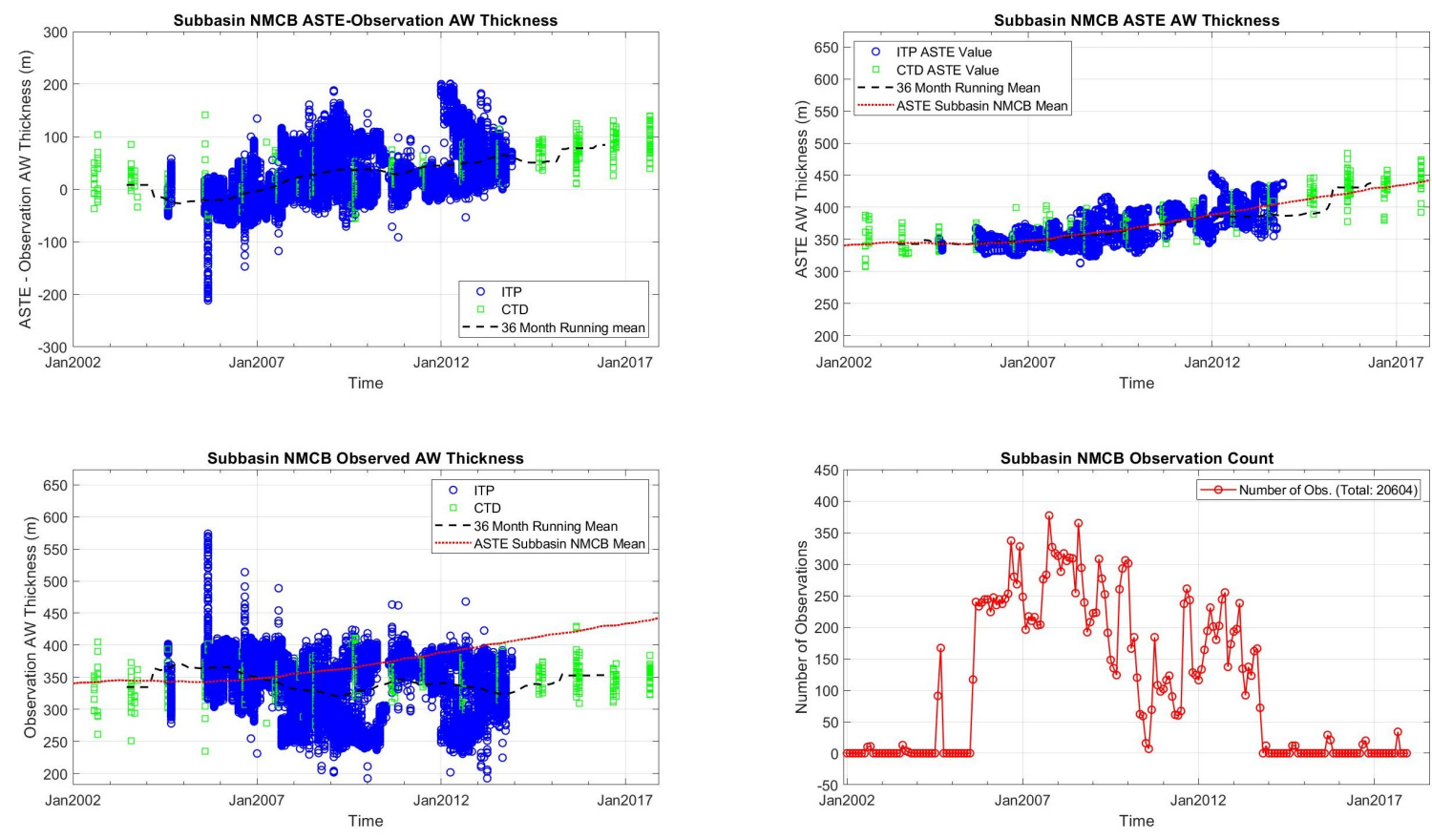

Figure 3-30: Top Left: The difference between the observed (CTD or ITP) AW thickness and the ASTE AW thickness for the closest grid location to the observation at the time of each observation in the NMCB subbasin. A 36 month running mean of the differences is plotted in a black dashed line. Top Right: The ASTE AW thickness for the closest grid location to the observation during the month of the observation. The black dashed line is a 36 month running mean of the ASTE AW thickness values at the nearest grid location to the observation. The red line is the overall subbasin mean ASTE AW thickness value. Bottom Left: The observed AW thickness for CTDs (squares) and ITP (circles). The red line is the overall subbasin mean ASTE AW thickness value. Bottom Right: The number of observations in the NMCB subbasin for each month of ASTE output.

The NMCB mean $1028.2 \mathrm{~kg} / \mathrm{m}^{3}$ isopycnal depth increased with time in ASTE from approximately $160 \mathrm{~m}$ at the beginning of the state estimate period to $200 \mathrm{~m}$ by the conclusion. The monotonic increase begins in 2004. This gradual deepening occurs in the subbasin that contains the Beaufort Gyre; a region which has been accumulating freshwater [37]. This would explain the gradual deepening of the $1028.2 \mathrm{~kg} / \mathrm{m}^{3}$ isopycnal. Observations of the $1028.2 \mathrm{~kg} / \mathrm{m}^{3}$ depth and their ASTE counterpart are similar with a running mean difference near zero for the duration of the ASTE output. 

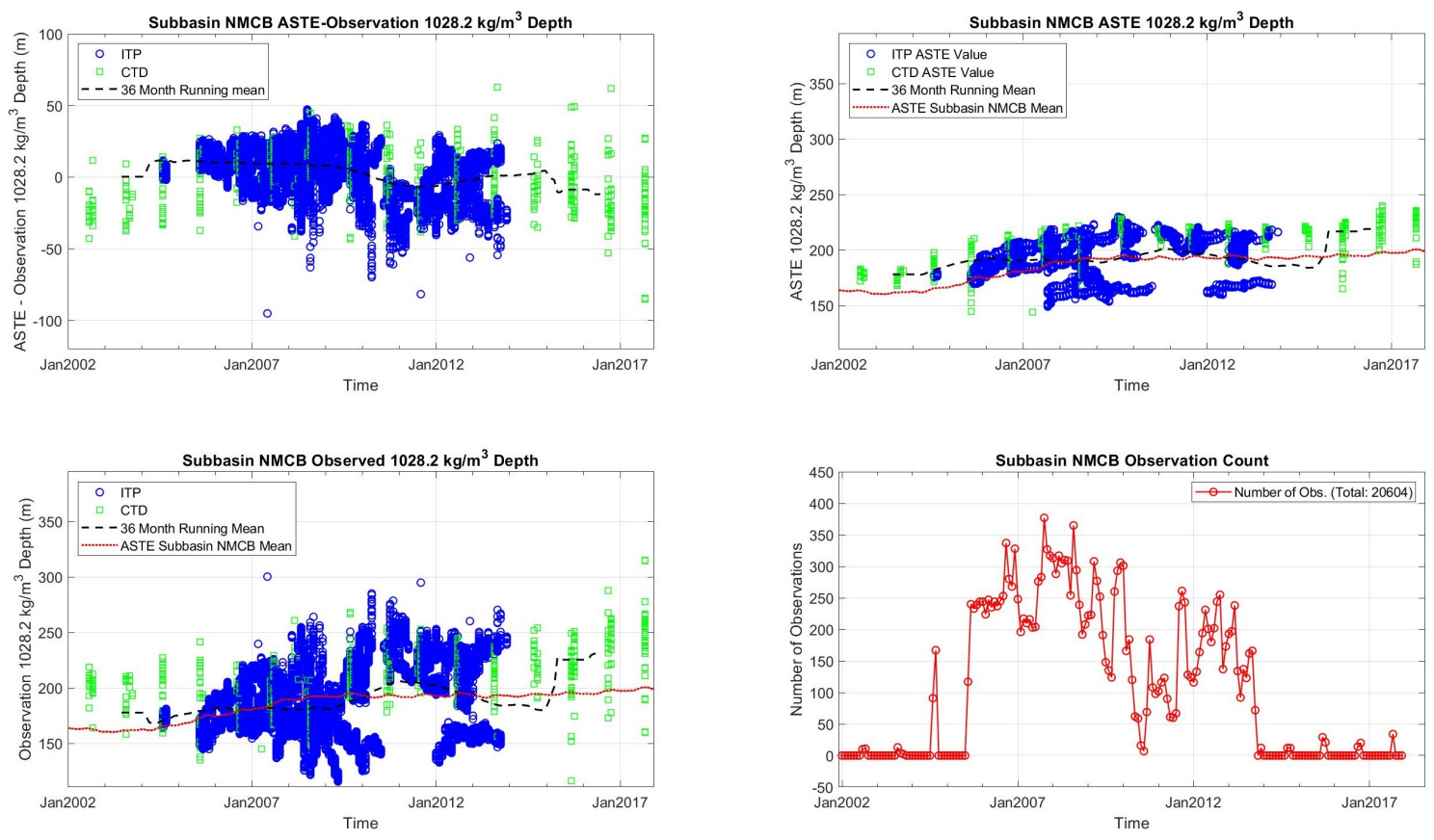

Figure 3-31: Top Left: The difference between the observed (CTD or ITP) $1028.2 \mathrm{~kg} / \mathrm{m}^{3}$ depth and the ASTE $1028.2 \mathrm{~kg} / \mathrm{m}^{3}$ depth for the closest grid location to the observation at the time of each observation in the NMCB subbasin. A 36 month running mean of the differences is plotted in a black dashed line. Top Right: The ASTE $1028.2 \mathrm{~kg} / \mathrm{m}^{3}$ depth for the closest grid location to the observation during the month of the observation. The black dashed line is a 36 month running mean of the ASTE $1028.2 \mathrm{~kg} / \mathrm{m}^{3}$ depth values at the nearest grid location to the observation. The red line is the overall subbasin mean ASTE $1028.2 \mathrm{~kg} / \mathrm{m}^{3}$ depth value. Bottom Left: The observed $1028.2 \mathrm{~kg} / \mathrm{m}^{3}$ depth for CTDs (squares) and ITP (circles). The red line is the overall subbasin mean ASTE $1028.2 \mathrm{~kg} / \mathrm{m}^{3}$ depth value. Bottom Right: The number of observations in the NMCB subbasin for each month of ASTE output.

ASTE exhibits $1028.9 \mathrm{~kg} / \mathrm{m}^{3}$ isopycnal depths also increasing monotonically with time in the NMCB (Figure 3-32). In January 2002 the mean model NMCB bottom isopycnal depth is $500 \mathrm{~m}$ which increases to approximately $650 \mathrm{~m}$ in December 2017 . The closest grid locations to the observations follow the deepening trend seen in the subbasin mean. The observed isopycnal depths show a similar deepening trend although less steady. The observed 36 month running mean begins at $500 \mathrm{~m}$ depth along with the ASTE subbasin mean, but instead of steadily increasing, it oscillates between $500 \mathrm{~m}$ and $550 \mathrm{~m}$ before increasing to near $600 \mathrm{~m}$ by the end of the state estimate period. The observations show a much wider range in $1028.9 \mathrm{~kg} / \mathrm{m}^{3}$ depth isopycnal depths $(\sim 300 \mathrm{~m})$ within the subbasin at any given time where as the same locations in ASTE only show a $100 \mathrm{~m}$ variation. Some of the variability in the observations is due to eddy variability which is not captured in the medium spatial 
resolution ASTE model monthly mean output. The ASTE to observed $1028.9 \mathrm{~kg} / \mathrm{m}^{3}$ depth misfits are as large as $200 \mathrm{~m}$. The 36 month running mean of the difference begins near zero but increases to $80 \mathrm{~m}$ by 2016. This indicates ASTE is generally deeper than the actual $1028.9 \mathrm{~kg} / \mathrm{m}^{3}$ depth with a difference that grows in time. The misfit in bottom AW bounding isopycnal depths is also the cause for the AW thickness discrepancy.
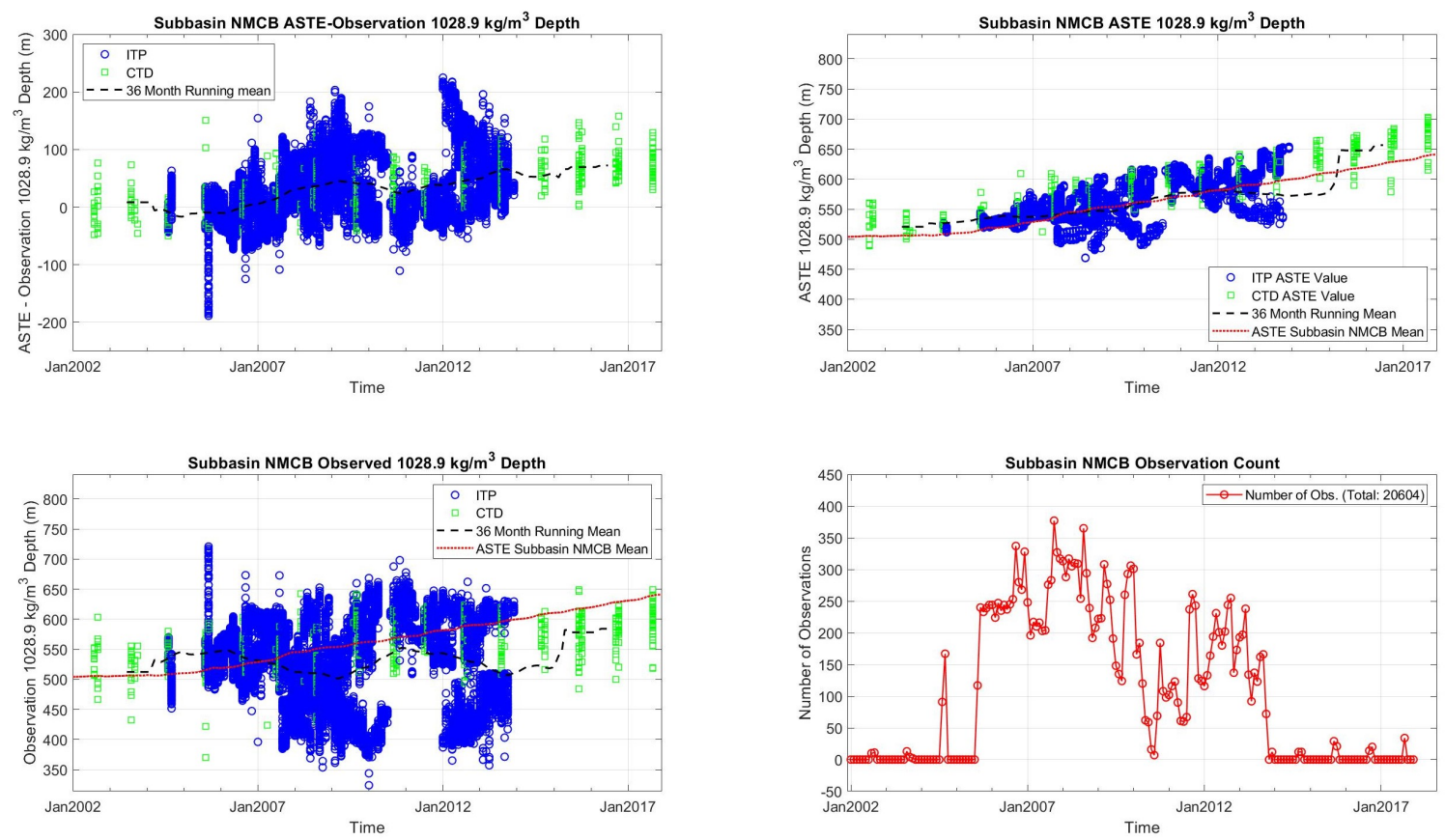

Figure 3-32: Top Left: The difference between the observed (CTD or ITP) $1028.9 \mathrm{~kg} / \mathrm{m}^{3}$ depth and the ASTE $1028.9 \mathrm{~kg} / \mathrm{m}^{3}$ depth for the closest grid location to the observation at the time of each observation in the NMCB subbasin. A 36 month running mean of the differences is plotted in a black dashed line. Top Right: The ASTE $1028.9 \mathrm{~kg} / \mathrm{m}^{3} \mathrm{depth}$ for the closest grid location to the observation during the month of the observation. The black dashed line is a 36 month running mean of the ASTE $1028.9 \mathrm{~kg} / \mathrm{m}^{3}$ depth values at the nearest grid location to the observation. The red line is the overall subbasin mean ASTE $1028.9 \mathrm{~kg} / \mathrm{m}^{3}$ depth value. Bottom Left: The observed $1028.9 \mathrm{~kg} / \mathrm{m}^{3}$ depth for CTDs (squares) and ITP (circles). The red line is the overall subbasin mean ASTE $1028.9 \mathrm{~kg} / \mathrm{m}^{3}$ depth value. Bottom Right: The number of observations in the NMCB subbasin for each month of ASTE output. 


\section{Chapter 4}

\section{Conclusions and Future Work}

This study is the first to analyze the ASTE monthly mean output for the AW Layer and compare output to observed AW Layer properties. While monthly mean output does not permit an analysis of AW property variability due to eddies, it does permit an analysis of basin wide seasonal to interannual AW variability and a description of the AW time-mean circulation and its properties for the AO.

The ASTE solution analyzed here was obtained through 62 iterations of optimization. A significant, sustained shift in AW properties is observed in the state estimate a couple years after the solution initial time of January 2002. A surge of AW enters the AO in 2004 at Fram Strait and increases the AW Layer mean potential temperature, bottom AW bounding isopycnal depth, and boundary current speed as it traverses the AO. Since there is not much change in the top AW bounding isopycnal, the AW Layer thickness throughout the AO also increases. The surge enters the AO proper along the continental shelf north of Svalbard and traverses cyclonically to the Laptev Sea with a bifurcation in the flow at the Lomonosov Ridge. The signal moves along the major AW boundary currents and ridge at approximately $2 \mathrm{~cm} / \mathrm{s}$ which indicates this signal is likely advected in the AO. As the surge extends along the Lomonosov Ridge from 2004 through 2008, the direction of the flow there reverses from toward Eurasia to toward North America. Some of the surge crosses the Lomonosov Ridge enroute to the pole as AW property changes are seen to spread into the Makarov Basin and eventually extend to the other side of the Mendeleyev Ridge in the Canada Basin while enroute to the North American continental shelf. Affected AW properties change first along the AW boundary currents and later spread into the mid basins. The magnitude of the 
change for each affected AW parameter is dependent upon location and distance from AW inflow areas, with the largest changes near AW source regions.

The cause of the surge in ASTE, whether due to an observational constraint in the model, a result of internal model physics, or mechanisms external to the $\mathrm{AO}$, is hypothesized to be connected to changes in the ocean state and circulation much further upstream in the North Atlantic and Nordic Seas [19] which resulted in a shift of the repartitioning of AW inflow between the Iceland-Faroe and Faroe-Scotland Ridges and stronger northward transport of AW into the Arctic Ocean across Fram Strait. The flow direction along the Lomonosov Ridge from 2002 through surge passage is opposite the inferred flow direction based on hydrographic observations in previous investigations. The surge adjusts the model to a quasi-steady AW circulation for the rest of the state estimate period which more closely aligns with accepted AW circulation schemes. The described behavior raises the question if a wave, such as a Kelvin wave, is propagating along bathymetry and adjusting the model to a new steady-state. A wave seems unlikely since the speed of the surge along the boundary currents was the same magnitude as the boundary current speed $(\sim 2 \mathrm{~cm} / \mathrm{s})$, much slower than the theoretical first vertical mode return wave. Moreover, the time stepping employed in ASTE quickly damps fast Kelvin waves in a few wave periods [38]. If the surge is real, then observations constraining the model should record the event. This investigation did not analyze mooring observations, particularly at Fram Strait, which could verify the existence of the surge in velocity data, but this study did analyze observed AW properties from CTDs and ITPs. These observations did not show an abrupt increase in AW $\Theta_{a v}$ or bottom bounding isopycnal depth during the time frame in question. However, observations are limited and not well distributed in space or time.

Two physical mechanisms driving the AW circulation into and out of the AO have been developed in previous research. One evokes a two-layer, estuary framework as described by Rudels, 1989 [39] and Stigebrandt, 1981 [40] where a cool, fresh layer overlies a warm, salty layer. For a fixed freshwater input at the surface (e.g. river-runoff and net precipitation), the amount of AW entering the AO depends on the mixing between the two layers, with increased mixing resulting in more AW entering the AO. The internal framework of ASTE could be used to test if the surge is a result of an increase in the overturning circulation since the surge does not occur until a couple years after the initial time of the state estimate.

The other concept for driving AW flow into and around the AO is based on wind forcing 
and potential vorticity (PV). In the absence of forcing, PV is conserved and the conservation of PV requires water to flow along $f / H$ contours where ' $f$ ' is the Coriolis parameter and ' $H$ ' is the water depth. Since the $f$-plane approximation (constant $f$ ) can be applied to the Arctic, PV contours closely follow isobaths. As discussed in Timmermans and Marshall, 2020 [11], the integral of the wind stress curl within an enclosed $f / H$ contour may be related to the circulation around that contour and results in an AW Layer that is driven by the wind stresses in the Nordic Sea. Thus, forcing external to the AO could be resulting in the surge observed within ASTE. Since the ASTE domain stretches to $32.5^{\circ} \mathrm{S}$, surface forcing in the Nordic Sea could be tested within the model as a potential source of increased AW flow.

A quasi-steady-state is attained in ASTE for both the Lomonosov Boundary Current and Circumpolar Boundary Current by 2010 which continues through the end of the state estimate period. The time-mean circulation during this time period contains two boundary currents; the Lomonosov Boundary Current and the Circumpolar Boundary Current with the majority of the AW turning poleward at the Lomonosov Ridge $(\sim 2.4 \mathrm{~Sv}$ vs. $\sim 0.5$ Sv). A significant fraction of the AW crosses the Lomonosov Ridge rather than paralleling the ridge and turning directly toward Fram Strait, which is not depicted in the generalized AW flows from Mauritzen et al., 2013 [1] adapted from Rudels et al., 2012 [2]. Additional smaller, semi-permanent AW circulations were seen adjacent to the Lomonosov Ridge and primary boundary currents as well as under the Beaufort Gyre. This generalized pattern describes both the full and non-divergent flow.

The amount of AW crossing the Lomonosov Ridge into the Makarov Basin in ASTE, either at the ridge-continental slope junction or farther north along the ridge, could be sensitive to the model resolution. It is well known that coarse grid resolution or the representation of the bathymetry in numerical models can limit the flow of water over bathymetric obstructions. Mooring observations, preferentially about the deep passages along the Lomonosov Ridge, could provide key estimates of the AW volume transport and associated heat flux into the basins beyond. Additional observations could be obtained by UUVs operating along the ridge. Of course operating in this region is difficult due to sea ice and seasonal conditions that constrain access to this area. However, the additional data would assist in constraining ocean state estimates such as ASTE and provide better estimates for the AW circulation in this region, with implications for improving estimation of the overall global energy budget 
due to the water mass transformations occurring within the AO.

The seasonal cycle of AW in the AO reveals the greatest (least) volume transport of AW and most (least) vigorous boundary current during winter (summer). The mean AW inflow at Fram Strait ( $\sim 3.6 \mathrm{~Sv}$ with $\sim 1.8 \mathrm{~Sv}$ immediately recirculating) is greater than the Barents Sea $(\sim 1.5 \mathrm{~Sv})$. The mean AW outflow through Fram Strait $(\sim 2.2 \mathrm{~Sv})$ is greater than the Canadian Archipelago ( $\sim 0.3 \mathrm{~Sv})$ which is limited to the Nares Strait. This result could be further examined to see if a wind-driven model for AW circulation reproduces similar seasonal fluctuations and volume transport. Modification to a simplified three-layer model such as the one Spall, 2013 [41] developed with a uniform-stress over the AO and Nordic Sea, could further analyze mechanisms varying AW volume transport circulation.

The divergent part of the flow describes the overturning circulation and thus water mass transformations within the AO. Analysis of the Surface Layer revealed only a $0.1 \mathrm{~Sv}$ rate of volume increase from 2010-2017 while the AW Layer had a rate of volume increase of 1.4 $\mathrm{Sv}$ and the Bottom Layer rate of volume decrease was $1.5 \mathrm{~Sv}$. This is reflected in the greater increases in the $1028.9 \mathrm{~kg} / \mathrm{m}^{3}$ isopycnal depth than the $1028.2 \mathrm{~kg} / \mathrm{m}^{3}$ in the AO. When combined with net ocean transport, continuity reveals that in the ASTE state estimate more AW is converted to relatively fresh, cold Surface Layer water (1.2 Sv) than to more saline and colder Bottom Layer water $(0.4 \mathrm{~Sv})$. The mechanisms driving these conversions were not investigated but could be conducted within the ASTE framework. Specific locations to investigate include mixing along the continental shelf and ridges which are likely locations where AW is transformed to Bottom Layer water. The thickening of the AW Layer and thinning of the Bottom Layer might indicate ASTE is not transforming enough AW to denser waters. This may be a result of limited deep hydrographic data to constrain the model. Additionally, a spatial analysis of where AW is preferentially converted to Surface Layer water would provide insight into the processes driving this transformation which is important to the "Atlantification" of the AO already observed in the Eurasian Basin [4].

The framework of ASTE provides the opportunity to investigate parameters determining AW properties in the AO. The mean AW Layer temperature is warmest $\left(2.67^{\circ} \mathrm{C}\right)$ in Fram Strait when it enters the AO via the West Spitsbergen Current. The warmest water follows the boundary currents with cooler AW water away from the shelves and ridges. The thickest AW Layer is along the continental shelf from Franz Josef Land to the Laptev Sea and along 
the Lomonosov Ridge up to the pole. This is a result of the lower AW bounding isopycnal, $1028.9 \mathrm{~kg} / \mathrm{m}^{3}$, having the deepest depths in these regions since the upper AW bounding isopycnal, $1028.2 \mathrm{~kg} / \mathrm{m}^{3}$, varies nearly uniformly with increasing depths away from the AW inflow regions. The ASTE output is constrained by observations to provide a best-estimate of AO properties, but in the AW Layer, the difference between the model and observations generally increases during the state estimate period, with the AW Layer in ASTE being generally warmer and thicker than observations. More investigation into what parameters are causing the best-estimate to deviate from observations over time, including a more complete observational comparison than conducted in this study, would reveal determining factors for AW Layer evolution in the model. 
THIS PAGE INTENTIONALLY LEFT BLANK 


\section{Bibliography}

[1] Cecilie Mauritzen, Bert Rudels, and John Toole. The Arctic and Subarctic Oceans/Seas. International Geophysics Ocean Circulation and Climate - A 21st Century Perspective, page 443-470, 2013.

[2] Bert Rudels, Leif Anderson, Patrick Eriksson, Eberhard Fahrbach, Martin Jakobsson, E. Peter Jones, Humfrey Melling, Simon Prinsenberg, Ursula Schauer, and Tom Yao. Observations In The Ocean., volume 43, page 117-498. Springer Netherlands, 2012.

[3] L. K. Coachman and C. A. Barnes. The contribution of Bering Sea Water to the Arctic Ocean. Arctic, 14(3), Jan 1961.

[4] Igor V. Polyakov, Andrey V. Pnyushkov, Matthew B. Alkire, Igor M. Ashik, Till M. Baumann, Eddy C. Carmack, Ilona Goszczko, John Guthrie, Vladimir V. Ivanov, Torsten Kanzow, and et al. Greater role for Atlantic inflows on sea-ice loss in the Eurasian Basin of the Arctic Ocean. Science, 356(6335):285-291, Jun 2017.

[5] Bert Rudels, E. Peter Jones, Ursula Schauer, and Patrick Eriksson. Atlantic sources of the Arctic Ocean surface and halocline waters. Polar Research, 23(2):181-208, 2004.

[6] Agnieszka Beszczynska-Möller, Eberhard Fahrbach, Ursula Schauer, and Edmond Hansen. Variability in Atlantic water temperature and transport at the entrance to the Arctic Ocean, 1997-2010. ICES Journal of Marine Science, 69(5):852-863, 2012.

[7] Øystein Skagseth, Tore Furevik, Randi Ingvaldsen, Harald Loeng, Kjell Arne Mork, Kjell Arild Orvik, and Vladimir Ozhigin. Volume and heat transports to the Arctic Ocean via the Norwegian and Barents Seas. Arctic-Subarctic Ocean Fluxes, page 45-64, 2008 .

[8] Tore Hattermann, Pål Erik Isachsen, Wilken-Jon Appen, Jon Albretsen, and Arild Sundfjord. Eddy-driven recirculation of Atlantic Water in Fram Strait. Geophysical Research Letters, 43(7):3406-3414, 2016.

[9] Bert Rudels, Hans J. Friedrich, and Detlef Quadfasel. The Arctic Circumpolar Boundary Current. Deep Sea Research Part II: Topical Studies in Oceanography, 46(67):1023-1062, 1999.

[10] Sigrid Lind, Randi B. Ingvaldsen, and Tore Furevik. Arctic layer salinity controls heat loss from deep Atlantic layer in seasonally ice-covered areas of the Barents Sea. Geophysical Research Letters, 43(10):5233-5242, 2016. 
[11] Mary-Louise Timmermans and John Marshall. Understanding Arctic Ocean circulation: A review of ocean dynamics in a changing climate. Journal of Geophysical Research: Oceans, 125(4), 2020.

[12] L. G. Anderson, E. P. Jones, K. P. Koltermann, P. Schlosser, J. H. Swift, and D. W. R. Wallace. The first oceanographic section across the Nansen Basin in the Arctic Ocean. Deep Sea Research Part A. Oceanographic Research Papers, 36(3):475-482, 1989.

[13] J. H. Swift, E. P. Jones, K. Aagaard, E. C. Carmack, M. Hingston, R. W. Macdonald, F. A. Mclaughlin, and R. G. Perkin. Waters of the Makarov and Canada Basins. Deep Sea Research Part II: Topical Studies in Oceanography, 44(8):1503-1529, 1997.

[14] Michael Steele and Timothy Boyd. Retreat of the cold halocline layer in the Arctic Ocean. Journal of Geophysical Research: Oceans, 103(C5):10419-10435, 1998.

[15] Gary A. Maykut and Norbert Untersteiner. Some results from a time-dependent thermodynamic model of sea ice. Journal of Geophysical Research, 76(6):1550-1575, 1971.

[16] James E. Overland, Kevin R. Wood, and Muyin Wang. Warm Arctic - cold continents: climate impacts of the newly open Arctic Sea. Polar Research, 30(1):15787, 2011.

[17] Igor A. Dmitrenko, Igor V. Polyakov, Sergey A. Kirillov, Leonid A. Timokhov, Ivan E. Frolov, Vladimir T. Sokolov, Harper L. Simmons, Vladimir V. Ivanov, and David Walsh. Toward a warmer Arctic Ocean: Spreading of the early 21st century Atlantic Water warm anomaly along the Eurasian Basin margins. Journal of Geophysical Research, 113(C5), 2008.

[18] An T. Nguyen, Victor Ocaña, Vikram Garg, Patrick Heimbach, John Toole, Richard Krishfield, Craig Lee, and Luc Rainville. On the benefit of current and future ALPS data for improving Arctic coupled ocean-sea ice state estimation. Oceanography, 30(2):69-73, 2017.

[19] An T. Nguyen, Patrick Heimbach, Victor Ocana, Helen Pillar, and Arash Bigdeli. The Arctic Subpolar gyre sTate Estimate: a data-constrained and dynamically consistent ocean-sea ice estimate for 2002-2017. Unpublished Manuscript, 2020.

[20] John Marshall, Alistair Adcroft, Chris Hill, Lev Perelman, and Curt Heisey. A finitevolume, incompressible Navier Stokes model for studies of the ocean on parallel computers. Journal of Geophysical Research: Oceans, 102(C3):5753-5766, 1997.

[21] D. Menemenlis, C. Hill, A. Adcroft, J. Campin, B. Cheng, B. Ciotti, I. Fukumori, A. Koehl, P. Heimbach, C. Henze, T. Lee, D. Stammer, J. Taft, and J. Zhang. Towards eddy permitting estimates of the global ocean and sea-ice circulation. EOS Transactions $A G U, 86(9), 2005$.

[22] Martin Losch, Dimitris Menemenlis, Jean-Michel Campin, Patick Heimbach, and Chris Hill. On the formulation of sea-ice models. Part 1: Effects of different solver implementations and parameterizations. Ocean Modelling, 33(1-2):129-144, 2010.

[23] Patick Heimbach, Dimitris Menemenlis, Martin Losch, Jean-Michel Campin, and Chris Hill. On the formulation of sea-ice models. Part 2: Lessons from multi-year adjoint sea-ice export sensitivities through the Canadian Arctic Archipelago. Ocean Modelling, $33(1-2): 145-158,2010$. 
[24] Martin Jakobsson, Larry Mayer, Bernard Coakley, Julian A. Dowdeswell, Steve Forbes, Boris Fridman, Hanne Hodnesdal, Riko Noormets, Richard Pedersen, Michele Rebesco, and et al. The International Bathymetric Chart of the Arctic Ocean (IBCAO) Version 3.0. Geophysical Research Letters, 39(12), 2012.

[25] Walter H. F. Smith and David T. Sandwell. Global sea floor topography from satellite altimetry and ship depth soundings. Science, 277(5334):1956-1962, 1997.

[26] Richard B. Lammers, Alexander I. Shiklomanov, Charles J. Vörösmarty, Balázs M. Fekete, and Bruce J. Peterson. Assessment of contemporary Arctic river runoff based on observational discharge records. Journal of Geophysical Research: Atmospheres, 106(D4):3321-3334, 2001.

[27] Alexander I. Shiklomanov, Tatyana I. Yakovleva, Richard B. Lammers, Iosiph Ph. Karasev, Charles. J. Vörösmarty, and Ernst Linder. Cold region river discharge uncertainty - estimates from large Russian rivers. Journal of Hydrology, 326(1-4):231-256, 2006.

[28] Jinlun Zhang and D. A. Rothrock. Modeling global sea ice with a thickness and enthalpy distribution model in generalized curvilinear coordinates. Monthly Weather Review, 131(5):845-861, 2003.

[29] G. Forget, J.-M. Campin, P. Heimbach, C. N. Hill, R. M. Ponte, and C. Wunsch. ECCO version 4: an integrated framework for non-linear inverse modeling and global ocean state estimation. Geoscientific Model Development, 8(10):3071-3104, 2015.

[30] Carl Wunsch and Patrick Heimbach. Practical global oceanic state estimation. Physica D: Nonlinear Phenomena, 230(1-2):197-208, 2007.

[31] Fridtjof Nansen. The Norwegian North Polar Expedition: 1893-1896 ; scientific results. Dybwad, 1902.

[32] John Toole, Richard Krishfield, Mary-Louise Timmermans, and Andrey Proshutinsky. The Ice-Tethered Profiler: Argo of the Arctic. Oceanography, 24(3):126-135, Jan 2011.

[33] R. Krishfield, J. Toole, A. Proshutinsky, and M-L. Timmermans. Automated IceTethered Profilers for seawater observations under pack ice in all seasons. Journal of Atmospheric and Oceanic Technology, 25(11):2091-2105, 2008.

[34] Reiner Schlitzer. Ocean Data Viewer. odv.awi.de, 2020.

[35] K. Aagaard and E. C. Carmack. The role of sea ice and other fresh water in the Arctic circulation. Journal of Geophysical Research, 94(C10):14485, 1989.

[36] Rebecca A. Woodgate. Increases in the Pacific inflow to the Arctic from 1990 to 2015, and insights into seasonal trends and driving mechanisms from year-round Bering Strait mooring data. Progress in Oceanography, 160:124-154, 2018.

[37] A. Proshutinsky, R. Krishfield, J. M. Toole, M.-L. Timmermans, W. Williams, S. Zimmermann, M. Yamamoto-Kawai, T. W. K. Armitage, D. Dukhovskoy, E. Golubeva, G. E. Manucharyan, G. Platov, E. Watanabe, T. Kikuchi, S. Nishino, M. Itoh, S.-H. Kang, K.-H. Cho, K. Tateyama, and J. Zhao. Analysis of the Beaufort Gyre freshwater 
content in 2003-2018. Journal of Geophysical Research: Oceans, 124(12):9658-9689, 2019.

[38] An T. Nguyen. Personal communication, August 2020.

[39] Bert Rudels. The formation of polar surface water, the ice export and the exchanges through the Fram Strait. Progress in Oceanography, 22(3):205-248, 1989.

[40] Anders Stigebrandt. A Model for the thickness and salinity of the upper layer in the Arctic Ocean and the relationship between the ice thickness and some external parameters. Journal of Physical Oceanography, 11(10):1407-1422, 1981.

[41] Michael A. Spall. On the circulation of Atlantic Water in the Arctic Ocean. Journal of Physical Oceanography, 43(11):2352-2371, 2013. 